\author{
UNIVERSIDADE FEDERAL DE SÃO PAULO - UNIFESP \\ CENTRO DE DESENVOLVIMENTO DO ENSINO SUPERIOR EM SAÚDE \\ MESTRADO PROFISSIONAL ENSINO EM CIÊNCIAS DA SAÚDE
}

MARIA BERNADETE DE NORONHA DANTAS ROSSETTO

\title{
A EXPANSÃO DA GRADUAÇÃO NA UNIVERSIDADE FEDERAL DE SÃO PAULO NO PERÍODO DE 2003 A 2012
}

Dissertação apresentada à Universidade Federal de São Paulo para obtenção do título de Mestre Profissional em Ensino em Ciências da Saúde, do Programa de Mestrado Ensino em Ciências da Saúde, do Centro de Desenvolvimento do Ensino Superior em Saúde.

São Paulo 
MARIA BERNADETE DE NORONHA DANTAS ROSSETTO

\section{A EXPANSÃO DA GRADUAÇÃO NA UNIVERSIDADE FEDERAL DE SÃO PAULO NO PERÍODO DE 2003 A 2012}

Dissertação apresentada à Universidade Federal de São Paulo para obtenção do título de Mestre Profissional em Ensino em Ciências da Saúde, do Programa de Mestrado Ensino em Ciências da Saúde, do Centro de Desenvolvimento do Ensino Superior em Saúde.

Orientador: Prof. Dr. Nildo Alves Batista Co-orientadora: Profa. Dra. Paulete Goldenberg

São Paulo 
UNIVERSIDADE FEDERAL DE SÃO PAULO - UNIFESP CENTRO DE DESENVOLVIMENTO DO ENSINO SUPERIOR EM SAÚDE - CEDESS PROGRAMA DE MESTRADO ENSINO EM CIÊNCIAS DA SAÚDE

Coordenador do CEDESS: Prof. Dr. Nildo Alves Batista Coordenadora do Programa de Pós-graduação: Profa. Dra. Rosana Rossit 
Rossetto, Maria Bernadete de Noronha Dantas

A Expansão da graduação na Universidade Federal de São Paulo no período de 2003 a 2012/ Maria Bernadete de Noronha Dantas Rossetto. - São Paulo, 2017.

156 páginas

Dissertação (Mestrado Profissional) - Universidade Federal de São Paulo. Centro de Desenvolvimento do Ensino Superior em Saúde CEDESS.

Título em inglês: The Expansion of Graduation at the Universidade Federal de São Paulo from 2003 to 2012

1. Educação Superior. 2. Universidades. 3 Política Pública. 


\section{A EXPANSÃO DA GRADUAÇÃO NA UNIVERSIDADE FEDERAL DE SÃO PAULO NO PERÍODO DE 2003 A 2012}

São Paulo, 22 de setembro de 2017.

Orientador: Prof. Dr. Nildo Alves Batista

Universidade Federal de São Paulo

Centro de Desenvolvimento do Ensino Superior em Saúde

Profa. Dra. Simone Regina Souza da Silva Conde

Universidade Federal do Pará

Faculdade de Medicina - Instituto de Ciências da Saúde

Profa. Dra. Isabel Cristina Kowal Olm Cunha

Universidade Federal de São Paulo

Departamento de Administração e Saúde Coletiva

Profa. Dra. Iraní Ferreira da Silva Gerab

Universidade Federal de São Paulo

Centro de Desenvolvimento do Ensino Superior em Saúde 
Ao meu marido e filhos, sem vocês o meu caminho não teria sentido.

Aos meus pais, irmãos e irmãs, família tão especial e querida.

A Deus e à vida que me deram a oportunidade de ter conhecido e convivido com todos vocês. 


\section{Agradecimentos}

A Deus e ao plano espiritual que me permitiram estar entre as pessoas que amo e me ensinaram o que o aprendizado do convívio traz à alma.

À Professora Paulete Goldenberg, minha primeira orientadora, que me ensinou, com paciência e persistência, o sentido e a inspiração da pesquisa acadêmica.

Ao meu segundo orientador, Professor Nildo Batista, alma generosa e bondosa, que aceitou e respeitou minhas limitações e o meu tempo.

À minha banca examinadora: Professora Simone Conde, ser humano e espírito de luz maravilhosos; Professora Isabel Cunha, lúcida, prática e grande gestora administrativa, Professora Iraní Gerab, sempre disponível e querida tanto na escuta quanto nos anseios e Professora Cristina Tavares, que me proporcionou uma convivência e trocas de experiências importantes no CEDESS.

À Professora Regina Celes de Rosa Stella, com a qual tive a oportunidade de conviver e trabalhar em projetos e programas na UNIFESP, bem como pelos ensinamentos e convívio tão importantes para a minha vida.

Aos professores do mestrado que, com paciência e carinho, levaram-nos a caminhar pelos campos da pesquisa: Iraní Ferreira da Silva Gerab, Ively Guimarães Abdalla, José Antonio Marques Maia de Almeida, Lídia Ruiz-Moreno, Maria Cecília Sonzogno, Marilena Aparecida de Souza Rosalen, Nildo Alves Batista, Otília Maria Lúcia Barbosa Seiffert, Paulete Goldenberg, Sylvia Helena Souza da Silva Batista. Às professoras de disciplina eletiva Sonia Regina Abdalla Iglesias e Silvia Elsa Lizarralde de Pittamiglio.

Aos meus colegas do CEDESS e, em especial à Cristina, pela paciência em aceitar meu tempo e dedicação durante o período da dissertação; à Sueli, pelo seu apoio dado a tantos questionamentos feitos ao longo de todo o período do mestrado; à Gisela, sempre com seu sorriso meigo e carinhoso e a Rosely, com seu apoio tecnológico e de formatação. 
Aos meus colegas da UNIFESP: Miriam Elena Baceto, que me incentivou a fazer o mestrado no CEDESS; às queridas Angela Vitória Rodrigues Borges e Cristiane Regina da Silva (PROGRAD), pelo convívio carinhoso e gratificante; ao Renato Conte Pinto de Carvalho, gentil e querido.

Às minhas professoras, que me prepararam para o exame de proficiência na língua inglesa, Sonia Regina Abdalla Iglesias e Maria Cristina Iglesias Roa.

Aos mestrandos e doutorandos do CEDESS e, em especial, à Gisele Santos, à Patrícia Tavares, à Simone Lessa e à Ivanete Silva, pelas trocas de ideias, anseios e angústias.

Aos meus colegas de mestrado: Amanda, Adélia, Carlos, Cristiane, Francine, Gilmara, Gustavo, Izaias, Magali e Stefânia, um abraço forte. Foi uma experiência maravilhosa, ter passado esse tempo com vocês.

Aos amigos que conheci na vida, que dizem e trazem muito: Aninha, Bruno, Diego e Márcio.

Às queridas Mamadi e Mamagina, pessoas especiais e tão queridas.

Ao meu querido amigo, Cristiano, que sempre encontrou as palavras e o momento certos, para me auxiliar nas dúvidas e nas incertezas que passei com a dissertação.

À Nilza, minha amiga nestes longos anos, de paciência e companheirismo.

Ao meu sogro Darcy (in memoriam) e à minha sogra Bernadethe, por terem constituído a família Soldatelli Rossetto, abençoada com seus filhos Rafael, Miguel, Gabriel e Raquel, com seus netos Tomás, Gabriel, Andres, Eduardo, Marina, Sofia, Antonio e Heitor, seu genro Jaime e nora Karen Luana. Todos sempre trouxeram alegria para a minha vida. Malu querida, tu também moras no meu coração.

Aos meus irmãos José Geraldo (in memoriam), Mario, Salete, Fátima, Elisabeth e Beatriz, pessoas tão importantes na minha vida. Sempre estiveram comigo nos momentos decisivos. Todos vocês sempre trouxeram acalanto para o meu coração. Amo vocês. 
Aos meus sobrinhos queridos, com seus jeitos especiais: Karen, Cintia, Rafael, Rodolfo, Henrique, Daniel, Elisa, André, Leonardo, David e Julia, aos sobrinhos netos José Henrique, João Paulo, Fábio Yuri, Kalleo e Alana. Beijos em todos.

Às minhas cunhadas queridas Janete (in memoriam), Tania e Vera, alegria da convivência com esses anos. Ao querido cunhado Jorge, nosso poeta e escritor. Às queridas sobrinhas por terem casado com meus sobrinhos Nice e Luciana. À querida Taís Helena que está na nossa família por escolha da vida.

Aos meus pais queridos, Seu Dantas (in memoriam) e Dona Albertina (Betina, mamis fofeca, in memorian), pessoas que Deus e o plano espiritual escolheram para formar uma família tão querida e especial: a Família Noronha Dantas. Grandes lutadores e batalhadores que nos ensinaram a ter amor e respeito ao próximo. Sempre agradeço por ser filha de vocês e ter procurado seguir o que sempre nos ensinaram. Seu Dantas, beijo muito querido e Betina, beijo nesse teu coração lindo.

À minha família Dantas Rossetto. Ao meu esposo e amigo de 40 anos, Rafael. Muitos anos de trocas, cumplicidade e parceria. Eu te amo. Ao formar esta família com o Rafael, Deus e o plano espiritual nos propiciaram filhos maravilhosos, Matheus e Thiago. Pessoas do bem, queridas e as melhores que alguém possa desejar. Sigam, com amor, pelos caminhos da vida. Amo vocês. Deus também permitiu que nossos filhos escolhessem pessoas especiais para estar ao lado deles, a Bruna e a Bárbara. Também amo vocês. 


\section{Resumo}

A expansão das Instituições Federais de Ensino Superior (IFES) no Brasil foi um processo importante para o ensino superior no país, principalmente nas duas últimas décadas, e contou com o Programa de Expansão das Universidades Brasileiras e com o Programa de Apoio a Planos de Reestruturação e Expansão das Universidades Federais (REUNI). A Universidade Federal de São Paulo (UNIFESP) acompanhou esse processo nacional, com especificidades e grande transformação. Esta pesquisa objetivou analisar o processo de expansão da graduação na instituição, no período compreendido entre 2003 e 2012. Sua descrição foi feita desde a sua adesão ao processo nacional até o final da vigência do programa REUNI, bem como a sua análise em relação à expansão nacional das IFES, no período. Optou-se por realizar um estudo de caso, com percurso metodológico descritivo-analítico e análise documental. Os dados coletados foram analisados por meio da técnica de análise de conteúdo na modalidade temática. A análise, propriamente dita, deu-se com a leitura aprofundada dos documentos e identificação de 132 Unidades de Contexto (UC). Das UC, identificaram-se 341 Unidades de Registro (UR), das quais emergiram categorias e subcategorias. Os documentos incluídos nesta pesquisa foram publicações oficiais (12 documentos), legislações (4), atas das reuniões do Conselho Universitário da UNIFESP no período de 2003 a 2012 (141) e publicações da gestão da instituição. Esses documentos evidenciaram que o panorama geral da educação superior, na primeira fase da expansão (2003 a 2007), era de crise no ensino superior do Brasil e apontava para o reconhecimento do papel estratégico da educação superior pública e para a necessidade de uma reforma. No período entre 2008 e 2012, os documentos reforçaram o panorama já delineado, a necessidade de articulação dos eixos da expansão e a definição mais precisa das metas. Observou-se um crescimento global das IFES no processo de expansão (primeira fase e programa REUNI) de 31\% no número de universidades federais (de 45 para 59 ), de $106 \%$ no número de campi (de 148 para 305 ), de $125 \%$ no número de cursos (de 2078 para 4.672) e de 112\%, no número de vagas de ingresso (de 109.184 para 231.530). O processo de expansão na graduação na UNIFESP começou, efetivamente, em 2004. A partir dos dados quantitativos dos documentos analisados, observou-se um aumento percentual de 500\% no número de campi, $834 \%$ no número de vagas de ingresso e $980 \%$ no número de cursos. Além desse aumento quantitativo, a UNIFESP também diversificou sua área de atuação com a inclusão dos cursos de ciências humanas, sociais aplicadas e exatas. Considerou-se que o processo de expansão na Universidade, no período entre 2003 e 2012, pode ser considerado como único entre as IFES no Brasil, em relação ao que ocorreu no ensino superior público federal no país. Sua singularidade se dá tanto pelo potencial transformador dessa expansão como pelo crescimento do 
número de campi, cursos e matrículas da graduação, por meio de implementação de propostas pedagógicas inovadoras, bem como da diversificação de suas áreas de atuação, em relação aos parâmetros nacionais. Observou-se 0 caráter transformador que a expansão trouxe para a UNIFESP que, de uma universidade da área da saúde, passou para uma universidade plena.

Palavras-chave: Educação Superior. Universidades. Política Pública. 


\section{Abstract}

The expansion of the Federal Institutions of Higher Education (Instituições Federais de Ensino Superior - IFES) in Brazil was an important process for higher education in the country, especially in the last two decades, and counted on the Program for the Expansion of Brazilian Universities (Programa de Expansão das Universidades Brasileiras) and the Program for Support to Restructuring Plans and Expansion of Federal Universities (Programa de Apoio a Planos de Reestruturação e Expansão das Universidades Federais - REUNI). The Federal University of São Paulo (Universidade Federal de São Paulo - UNIFESP) has followed this national process, with specificities and great transformation. This research aimed to analyze the process of graduation expansion in the institution, between 2003 and 2012. Its description was made from its adhesion to the national process until the end of the REUNI program, as well as its analysis in relation to the national expansion of the IFES in the period. It was decided to carry out a case study, with a descriptiveanalytical methodology and documentary analysis. The collected data were analyzed through the technique of content analysis and thematic modality. The analysis, properly speaking, came about through in-depth reading of the documents and identification of 132 Contextual Units (UC). 341 Registration Units (UR) were identified of the UC, from which emerged categories and subcategories. The documents included in this research were official publications (12 documents), legislations (4), institution's management publications and Meeting Minutes of the University Council of UNIFESP, between 2003 and 2012 (141). The documents showed that the general panorama of higher education, in the first phase of the expansion (2003 to 2007) was a crisis in Brazil's higher education and pointed to the recognition of the strategic role of public higher education and the need for a reform of higher education. In the period between 2008 and 2012, the documents reinforced the panorama already outlined, the need to articulate the axes of expansion and the more precise definition of goals. There was an overall growth of IFES in the expansion process as a whole (first phase and REUNI program) of $106 \%$ in the number of campuses (from 148 to 305) and 125\% in the number of courses (from 2078 to 4,672). The process of graduation expansion at UNIFESP started, effectively, in 2004. From the quantitative data of the analyzed documents, it was observed that the percentage increase of $500 \%$ in the number of campuses, $834 \%$ in the number of places for admission and $980 \%$ in the number of courses. In addition to this quantitative increase, UNIFESP also diversified its area of activity with the inclusion of human, social, applied and exact science courses. The expansion process at the Federal University of São Paulo, between 2003 and 2012, can be considered as unique among the IFES in Brazil, in relation to what happened in the federal public higher education in the country. Its uniqueness is due both to the 
transformative potential of this expansion and to the growth in the number of campuses, undergraduate courses and enrollments, in relation to national parameters. We observed the transformative character that the expansion brought to UNIFESP, which, from a university in the area of health, became a full university.

Keywords: Higher Education. Universities. Public Policy. 


\section{Lista de abreviaturas}

ACE Avaliação das Condições de Ensino

ANDES Associação Nacional dos Docentes Universitários

ANDIFES Associação Nacional dos Dirigentes das Instituições Federais de Ensino Superior

BICT-Mar Bacharelado Interdisciplinar em Ciência e Tecnologia do Mar

CAPES Coordenação de Aperfeiçoamento de Pessoal de Nível Superior

CFE Conselho Federal de Educação

CNE Conselho Nacional de Educação

CNPq Conselho Nacional de Desenvolvimento Científico e Tecnológico

CONGRAD Conselho de Graduação

CONAES A Comissão Nacional de Avaliação da Educação Superior

CONSU Conselho Universitário

CTA Conselho Técnico-Administrativo

DES Departamento de Desenvolvimento do Ensino Superior

DOU Diário Oficial da União

ENC Exame Nacional de Cursos

FHC Fernando Henrique Cardoso

FURG Fundação Universidade do Rio Grande

GTI Grupo de Trabalho Interministerial

HSP Hospital São Paulo

ICMMA Instituto de Ciências do Mar e do Meio Ambiente

IES Instituições de Ensino Superior

IFES Instituições Federais de Ensino Superior

IPEA Instituto de Pesquisa Econômica Aplicada

LDB Lei de Diretrizes e Bases da Educação Nacional

MCT Ministério da Ciência e Tecnologia

MEC Ministério da Educação

MP Ministério do Planejamento

OCC Outros Custeios e Capital

PDE Plano de Desenvolvimento da Educação 


\begin{tabular}{ll} 
PDI & Plano de Desenvolvimento Institucional \\
PNE & Plano Nacional de Educação \\
ProUni & Programa Universidade para Todos \\
REUNI & $\begin{array}{l}\text { Programa de Apoio a Planos de Reestruturação e Expansão das } \\
\text { Universidades Federais }\end{array}$ \\
SENAC & Serviço Nacional de Aprendizagem Comercial \\
SENAI & Serviço Nacional de Aprendizagem Industrial \\
SESu & Secretaria de Educação Superior \\
SINAES & Sistema Nacional de Avaliação da Educação Superior \\
SiSU & Sistema de Seleção Unificado \\
SPDM & Associação Paulista para o Desenvolvimento da Medicina \\
UC & Unidade de Contexto \\
UFABC & Universidade Federal do ABC \\
UFAC & Fundação Universidade Federal do Acre \\
UFAL & Universidade Federal de Alagoas \\
UFAM & Fundação Universidade do Amazonas \\
UFBA & Universidade Federal da Bahia \\
UFC & Universidade Federal do Ceará \\
UFCG & Universidade Federal de Campina Grande \\
UFCSPA & Universidade Federal de Ciências da Saúde de Porto Alegre \\
UFERSA & Universidade Federal Rural do Semiárido \\
UFES & Universidade Federal do Espírito Santo \\
UFF & Universidade Federal Fluminense \\
UFFS & Universidade Federal da Fronteira Sul \\
UFG & Universidade Federal de Goiás \\
UFGD & Fundação Universidade Federal da Grande Dourados \\
UFJF & Universidade Federal de Juiz de Fora \\
UFLA & Universidade Federal de Lavras \\
UFMA & Fundação Universidade Federal do Maranhão \\
UFMG & Universidade Federal de Minas Gerais \\
UFMS & Fundação Universidade Federal de Mato Grosso do Sul \\
UFMT & Fundação Universidade Federal de Mato Grosso \\
\hline UFa
\end{tabular}




\begin{tabular}{ll} 
UFOP & Fundação Universidade Federal de Ouro Preto \\
UFOPA & Universidade Federal do Oeste do Pará \\
UFPA & Universidade Federal do Pará \\
UFPE & Universidade Federal de Pernambuco \\
UFPel & Fundação Universidade Federal de Pelotas \\
UFPI & Fundação Universidade Federal do Piauí \\
UFPR & Universidade Federal do Paraná \\
UFRA & Universidade Federal Rural da Amazônia \\
UFRB & Universidade Federal do Recôncavo da Bahia \\
UFRGS & Universidade Federal do Rio Grande do Sul \\
UFRJ & Universidade Federal do Rio de Janeiro \\
UFRN & Universidade Federal do Rio Grande do Norte \\
UFRPE & Universidade Federal Rural de Pernambuco \\
UFRR & Fundação Universidade Federal de Roraima \\
UFRRJ & Universidade Federal Rural do Rio de Janeiro \\
UFS & Fundação Universidade Federal de Sergipe \\
UFSC & Universidade Federal de Santa Catarina \\
UFSCar & Fundação Universidade Federal de São Carlos \\
UFSJ & Fundação Universidade Federal de São João Del Rei \\
UFSM & Universidade Federal de Santa Maria \\
UFT & Fundação Universidade Federal do Tocantins \\
UFTM & Universidade Federal do Triângulo Mineiro \\
UFTPR & Universidade Tecnológica Federal do Paraná \\
UFU & Universidade Federal de Uberlândia \\
UFV & Fundação Universidade Federal de Viçosa \\
UFVJM & Universidade Federal dos Vales do Jequitinhonha e Mucuri \\
UnB & Fundação Universidade de Brasília \\
UNFP & Universidade Federal da Paraíba \\
UNIFAL-MG Universidade Federal de Alfenas \\
UNIFAP & Fundação Universidade Federal do Amapá \\
UNIFEI & Universidade Federal de Itajubá \\
UNIFESP & Universidade Federal de São Paulo \\
\hline
\end{tabular}


UNILA Universidade Federal da Integração Latino-americana

UNILAB Universidade Federal da Integração Luso Afro-brasileira

UNIPAMPA Universidade Federal do Pampa

UNIR Fundação Universidade Federal de Rondônia

UNIRIO Universidade Federal do Estado do Rio de Janeiro

UNIVASF Fundação Universidade Federal do Vale do São Francisco

UR Unidade de Registro 


\section{Lista de Quadros}

Quadro 1. Universidades federais criadas entre 2003 e 2007, por região 64

Quadro 2. Universidade federais que aderiram ao REUNI na primeira chamada .....76

Quadro 3. Universidade federais que aderiram ao REUNI na segunda chamada ....78

Quadro 4. Número de vagas nos cursos de graduação em 2008, nas IFES. 79

Quadro 5. Universidades federais criadas entre 2008 e 2012 nas IFES, por região

Quadro 6. Indicadores globais da primeira fase da expansão da graduação e do REUNI nas universidades federais .82

Quadro 7. Campi, cursos e vagas, de acordo com ano de criação. .96

Quadro 8. Previsão de cursos e novas vagas para 2009, por campus, na UNIFESP. 101

Quadro 9. Previsão de cursos e novas vagas para 2010, no Campus Diadema da UNIFESP 102

Quadro 10. Distribuição das vagas de ingresso por campus, no ano de 2008, na UNIFESP. 103

Quadro 11. Distribuição das vagas de ingresso por campus, no ano de 2009, na UNIFESP. 103

Quadro 12. Distribuição das vagas de ingresso por campus, no ano de 2010, na UNIFESP. .104

Quadro 13. Distribuição de vagas de ingresso por campus, no ano de 2011, na UNIFESP. .104

Quadro 14. Distribuição de vagas de ingresso por campus, no ano de 2012, na UNIFESP .105

Quadro 15. Campus, cursos e vagas, de acordo com ano de criação 106

Quadro 16. Indicadores globais da primeira fase e da segunda fase da expansão da graduação na UNIFESP 


\section{Lista de Figura e Gráficos}

Figura 1. Etapas da análise de dados da pesquisa.............................................4

Gráfico 1. Campi criados e consolidados nas IFES, por região....................................64

Gráfico 2. Crescimento do número de vagas ofertadas nos cursos na graduação,

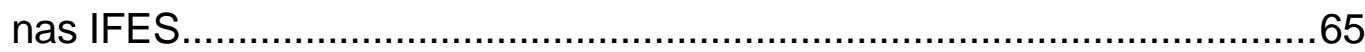

Gráfico 3. Crescimento do número de cursos na graduação, nas IFES....................66

Gráfico 4. Crescimento de número de matrículas na graduação, nas IFES...............66

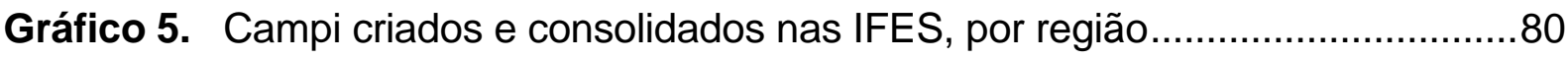

Gráfico 6. Crescimento do número de vagas ofertadas nos cursos na graduação,

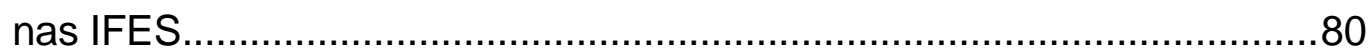

Gráfico 7. Crescimento do número de cursos na graduação, nas IFES .....................81

Gráfico 8. Crescimento do número de matrículas na graduação, nas IFES...............82

Gráfico 9. Crescimento do número de vagas ofertadas nos cursos na graduação,

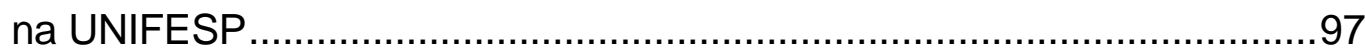

Gráfico 10. Crescimento do número de cursos na graduação, na UNIFESP...............98

Gráfico 11. Crescimento do número de matrículas na graduação, na UNIFESP.........98

Gráfico 12. Crescimento do número de vagas ofertadas nos cursos de graduação, na UNIFESP .............................................................108

Gráfico 13. Crescimento do número de cursos na graduação, na UNIFESP ............109

Gráfico 14. Crescimento do número de matrículas na graduação, na UNIFESP......110 


\section{Sumário}

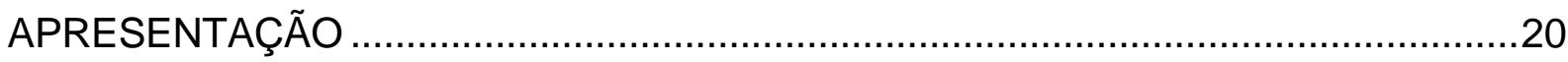

1 INTRODUÇÃO

2 OBJETIVOS

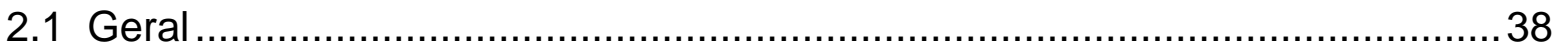

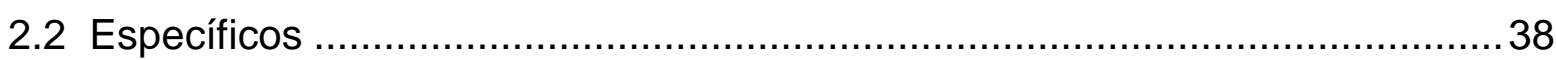

3 PERCURSO METODOLÓGICO

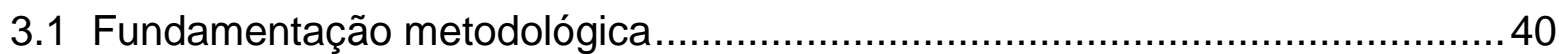

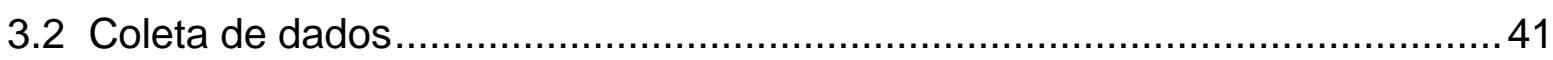

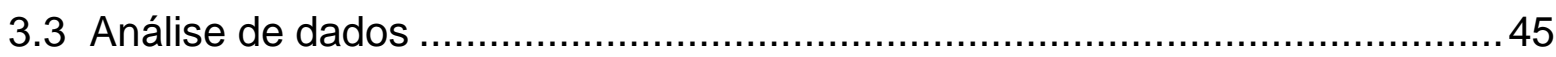

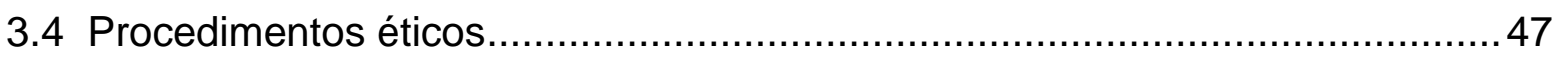

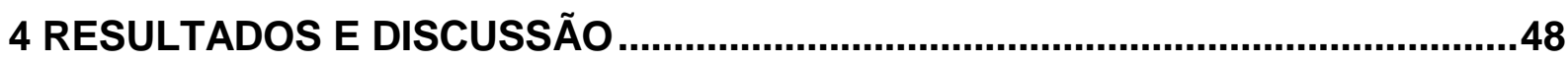

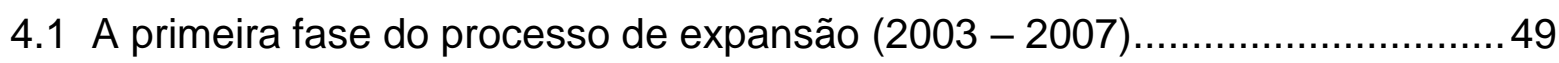

4.1.1 O panorama da educação superior no momento em que se iniciou a

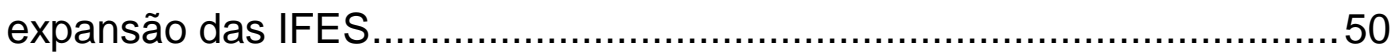

4.1.2 Motivos apontados, metas traçadas e primeiros documentos/legislação que sustentaram a primeira etapa de expansão das IFES .......................60

4.1.3 Resultados da primeira fase da expansão das IFES ...............................63

4.2 O REUNI na expansão das IFES (2008-2012) ….....................................67

4.2.1 Panorama da educação superior no Brasil no momento em que foi instituído o REUNI

4.2.2 As diretrizes, objetivos, dimensões e metas definidas para adesão ao REUNI.

4.2.3 Resultados do REUNI na expansão da graduação nas IFES (20082012)

4.3 A expansão na UNIFESP

4.3.1 A primeira fase de expansão (2003-2007): A criação de novos campi e cursos

4.3.2 A segunda fase de expansão e o Programa de Apoio a Planos de Reestruturação e Expansão das Universidades Federais (REUNI) na UNIFESP (2008-2012)

REFERÊNCIAS 


\section{APRESENTAÇÃO}

Sou Bernadete, gaúcha, da cidade de São Leopoldo, filha do Seu Dantas, natural do Jardim do Seridó, Rio Grande do Norte, e da Dona Albertina, natural de Cruz Alta, Rio Grande do Sul, esposa do Rafael e mãe do Matheus e do Thiago. Graduei-me em Licenciatura em Educação Artística, Habilitação Artes Cênicas, pela Universidade Federal do Rio Grande do Sul (UFRGS), em 1984.

Em 1980, ainda como estudante, ingressei no serviço público na própria UFRGS como Assistente Administrativo. Em 1985, já graduada, prestei novo concurso público para mudança de cargo e me tornei Técnico em Assuntos Educacionais.

Sou servidora pública por opção. Acredito que meu perfil pessoal e minha trajetória formativa, realizada sempre em instituições públicas, levaram-me a essa escolha. O desejo de contribuir com a educação pública e de desenvolver um bom trabalho me impulsionou a construir uma carreira comprometida com a universidade pública.

Os caminhos da vida me trouxeram à São Paulo e ingressei na Escola Paulista de Medicina (EPM) em 1994, ano em que foi criada a Universidade Federal de São Paulo (UNIFESP), alterando decisivamente os rumos desta instituição.

Desde então, desenvolvi inúmeras atividades no binômio educação e saúde. Assessorei projetos como o MERCOSUL Educacional do Ministério da Educação e o Programa de Interiorização do Trabalho em Saúde (PITS), o Programa de Incentivo às Mudanças Curriculares das Escolas Médicas (PROMED) e o Pró-Saúde do Ministério da Saúde. Colaborei na elaboração e redação das Diretrizes Nacionais Curriculares (DCN) para os cursos de Medicina, numa parceria da UNIFESP com a Associação Brasileira de Educação Médica (ABEM), bem como na organização de seminários nacionais e internacionais.

Em dezembro de 2009, completei 30 anos de serviço público junto ao Departamento de Comunicação e Marketing Institucional. Com uma experiência administrativa e executiva nas áreas de educação e saúde, inovação tecnológica e comunicação institucional, iniciei algumas reflexões: Qual é a minha vocação? Quais são as minhas habilidades e competências? O que produzi nesses anos todos? 
Decidi que precisava concretizar o fechamento da minha vida profissional nesta instituição e me inscrevi no Programa de Mestrado Profissional Ensino em Ciências da Saúde, do Centro de Desenvolvimento do Ensino Superior em Saúde (CEDESS), em 2010.

Em 2011, ingressei na Secretaria de Planejamento Acadêmico que, vinculada à reitoria, apoiava as pró-reitorias e diretorias acadêmicas de campus na tomada de decisão em relação ao processo de expansão da UNIFESP, iniciado em 2003. A secretaria tinha o intuito de desenvolver estudos e propostas de continuidade do crescimento acadêmico da instituição para áreas estratégicas, tanto para o desenvolvimento da própria universidade como para o desenvolvimento nacional, com projetos acadêmicos também estratégicos e inovadores.

O meu campo de trabalho compreendia a assessoria a esses projetos acadêmicos, o que resultou em uma motivação para pesquisar a expansão da graduação na UNIFESP. Entretanto, alguns contratempos me forçaram, por alguns anos, a um afastamento das atividades acadêmicas do mestrado. Nesse momento, com o sentimento de dever cumprido, apresento minha pesquisa concluída. 
1 INTRODUÇÃO 


\section{INTRODUÇÃO}

Para se chegar ao panorama atual do ensino superior, como um todo, no Brasil, nota-se uma evolução gradual no decorrer de sua história. Sua origem remonta ao século XIX quando toda a Corte se transferiu para a Colônia (Período Monárquico 1808 - 1889), a fim de fugir de Napoleão Bonaparte, na Europa. Apenas em 1808, é que foram criadas as primeiras instituições de ensino superior. Por sua vez, as primeiras universidades tiveram a sua criação, mais de um século depois, na década de 1930 (DURHAM, 2005).

A primeira Constituição Brasileira, outorgada em 1824, permitiu a descentralização do ensino superior e, consequentemente, o aparecimento de novas instituições, tanto as de caráter público (estaduais e municipais), as da iniciativa privada, quanto a criação de estabelecimentos confessionais no país. No Brasil, entre 1889 e 1918, foram criadas 56 novas escolas superiores, em que a grande maioria era da iniciativa privada. Naquele momento, o cenário da educação estava dividido da seguinte maneira: de um lado, as instituições católicas, empenhadas em oferecer uma alternativa confessional ao ensino público e, de outro, as iniciativas de elites locais que buscavam dotar seus estados de estabelecimentos de ensino superior (DURHAM, 2005).

Em 1890, Benjamim Constant, então ministro da Instrução Pública, Correios e Telégrafos, elaborou uma reforma de ensino que regulamentou a instrução primária, secundária, normal e superior e tinha, como princípios orientadores, a liberdade e laicidade do ensino (XAVIER, 1994).

De acordo com Frauches:

\footnotetext{
A legislação permite a existência de estabelecimentos particulares, sob a denominação de "Faculdades Livres", como concessão do Poder Público, "com todos os privilégios e garantias de que gozarem as faculdades federais". (FRAUCHES, on line, s/d).
}

Sob a presidência de Hermes da Fonseca, Rivadávia Correa, então ministro da Justiça e Negócios Interiores, aprovou a Lei Orgânica do Ensino Superior e do Fundamental, por meio do Decreto no 8.659 de 5 de abril de 1911 (BRASIL, 1911), no qual foram mantidos os currículos e as cadeiras da Reforma Benjamim Constant 
para os cursos superiores existentes. Essa Reforma modificou a estrutura do ensino superior em todo o Brasil, marcada pela desoficialização e descentralização do ensino (FREIRE, 1993), retirando da União o monopólio da criação de instituições de ensino superior. Pela Lei, o governo dispensava a exigência de equiparação a uma instituição modelo de nível federal, o que tornava possível a criação de universidades pela iniciativa privada (CHAGAS, 1979).

Para Fávero (2006), postergava-se o surgimento da universidade, embora apoiado em ato do governo federal. O regime de "desoficialização" do ensino acabou por gerar condições para o surgimento de universidades, com a tendência a um deslocamento provisório da órbita do governo federal, para a dos Estados. Nesse contexto, surge, em 1909, a Universidade de Manaus; em 1911 é instituída a de São Paulo; e, em 1912, a do Paraná como instituições livres (MICHELOTTO; COELHO; ZAINKO, 2006).

Carlos Maximiliano, então ministro da Justiça e Negócios Interiores, aprovou o Decreto $\mathrm{n}^{\circ}$ 11.530, de 18 de março de 1915, que reorganizou o ensino secundário e o superior que se configurou com a retomada da centralização (VIEIRA, 2009). A Reforma Carlos Maximiliano manteve o Conselho Superior de Ensino, mas alterou o currículo das seguintes instituições: Faculdades Federais de Direito (Pernambuco e São Paulo); Faculdade de Medicina (Bahia e Rio de Janeiro); Faculdade de Odontologia, de Farmácia e Escola Politécnica (Rio de Janeiro), Faculdade de Engenharia Civil, de Mecânica, de Eletricidade e Industrial. O artigo 6ํㅜ desse decreto, dispõe que:

O Governo Federal, quando achar opportuno, reunirá em Universidade as Escolas Polytechnica e de Medicina do Rio de Janeiro, incorporando a ellas uma das Faculdades Livres de Direito dispensando-a da taxa de fiscalização e dando-Ihe gratuitamente edificio para funccionar (BRASIL, 1915).

Na década de 1920, é desencadeado um movimento de modernização do país. Depois da Primeira Guerra Mundial, além do crescimento industrial, o Brasil passou a intensificar e a diversificar as suas relações comerciais e financeiras, principalmente, com os Estados Unidos. Além das transformações econômicas, culturais e urbanas, a industrialização do país trouxe as ideias de reformas do ensino como um todo, com o ensino primário público, universal e gratuito. A 
proposta de reforma do ensino superior envolveria substituir todo o sistema existente. Propunha-se bem mais do que uma simples criação de uma universidade. Pretendia-se uma ampla reforma de todo o sistema de ensino superior, substituindo as escolas autônomas por grandes universidades, com espaço para o desenvolvimento das ciências básicas e das pesquisas (DURHAM, 2005).

A Reforma João Luiz Alves, também chamada Lei Rocha Vaz, surgiu, em 1925, sob a presidência de Arthur Bernardes, com o Decreto ํㅜ 16.782-A, de 13 de janeiro (BRASIL, 1925). Este decreto estabeleceu o concurso da União para a difusão do ensino primário; criou o Conselho Nacional do Ensino em substituição ao Conselho Superior de Ensino; reformou o ensino secundário e o superior; e alterou o currículo dos cursos de Direito, Medicina, Farmácia, Odontologia e Engenharias (Civil, Elétrica e Industrial). Promoveu, ainda, novas alterações na regulamentação do ensino superior, reforçando o controle do governo federal (FRAUCHES, on line, $\mathrm{s} / \mathrm{d})$.

A Revolução de 1930 permitiu que o Brasil pudesse investir no mercado interno e na produção industrial. A nova realidade brasileira exigia mão de obra especializada e, para tal, era preciso investir na educação.

\footnotetext{
Somente com a Revolução de 30, que trouxe Getúlio Vargas ao poder, a educação se tornou prioridade nacional. Porém, embora o governo Vargas criasse uma burocracia muito centralizada para o ensino superior, não assumiu a responsabilidade pela gerência e administração das escolas, que continuaram nas mãos da iniciativa privada ou por conta das autoridades estaduais e municipais (SCHWARTZMAN, 2005).
}

Nesse mesmo ano foi criado o Ministério da Educação e Saúde Pública, pelo Decreto no 19.402 de 14 de novembro de 1930 (BRASIL, 1930), com a sanção do governo provisório que organizou 0 ensino secundário e as universidades brasileiras, ainda, embrionárias. Nesse contexto, surgiu a Reforma Francisco Campos, então ministro, estabelecida em três partes: criação do Conselho Nacional de Educação (CNE) pelo Decreto o 19.850, de 11 de abril de 1931 (BRASIL, 1931a); a promulgação do Estatuto das Universidades Brasileiras pelo Decreto no 19.851 de 11 de abril de 1931 (BRASIL, 1931b); com o Decreto no 19.852 de 11 de abril de 1931; e a organização da Universidade do Rio de Janeiro (BRASIL, 1931c). 
Essa foi a primeira reforma a colocar a universidade como modelo para o desenvolvimento do ensino superior, bem como estabelecer a organização, a composição, a competência e o funcionamento da administração universitária (reitoria, conselho universitário, assembleia geral universitária, institutos, conselho técnico-administrativo, congregação etc.), prevendo a representação estudantil (COLOMBO; CARDIM, 2010). As universidades poderiam ser criadas e mantidas pela União e/ou pelos Estados, sob a forma de fundações ou de associações, por particulares, constituindo universidades federais, estaduais e livres. A reforma reafirmou o professor catedrático como o primeiro na hierarquia do corpo docente e colocou, como exigência para o provimento no cargo, o concurso público de títulos e provas (FÁVERO, 1980).

Pela primeira vez, introduz-se a investigação científica, como um dos objetivos do ensino universitário no Brasil. De acordo com o artigo 1ํ, do decreto:

\begin{abstract}
O ensino universitario tem como finalidade: elevar o nivel da cultura geral, estimular a investigação scientifica em quaesquer dominios dos conhecimentos humanos; habilitar ao exercicio de actividades que requerem preparo technico e scientifico superior; concorrer, emfim, pela educação do individuo e da collectividade, pela harmonia de objectivos entre professores e estudantes e pelo aproveitamento de todas as actividades universitarias, para a grandeza na Nação e para o aperfeiçoamento da Humanidade (BRASIL, 1931b)
\end{abstract}

Em meio à desconsideração das camadas populares, no âmbito do ensino, registra-se a criação do Serviço Nacional de Aprendizagem Industrial (SENAI), pelo Decreto-Lei No 4.048 de 22 de janeiro de 1942 (BRASIL, 1942) e do Serviço Nacional de Aprendizagem Comercial (SENAC), pelo Decreto-Lei No 8.621 de 10 de janeiro de 1946 (BRASIL, 1946b), patrocinados pela indústria e comércio, com vistas à preparação técnica para o mercado de trabalho, no contexto do desenvolvimento urbano-industrial. Ao lado de iniciativas dessa ordem, o ensino secundário e superior continuavam a ser orientados por um ensino para as elites (ROMANELLI, 2003).

Com o término da Segunda Guerra Mundial, muitas mudanças aconteceram, o que provocou alterações nos sistemas educacional e da saúde. Com a deposição do presidente Getúlio Vargas, em outubro de 1945, e o fim do Estado Novo, o país entra em uma nova fase de sua história. Inicia-se um movimento para repensar o que estava identificado com o regime autoritário, até então vigente. A chamada 
"redemocratização do país" é consubstanciada na promulgação de uma nova Constituição, em 16 de setembro de 1946 (BRASIL, 1946a) que se caracterizou, de modo geral, pelo caráter democrático de seus enunciados¹ (FÁVERO, 2006).

Com a relativa ampliação de universidades públicas no início dos anos 1950, começam a se esboçar nas universidades algumas tentativas de luta por uma autonomia. Multiplicam-se as universidades, com predomínio da formação profissional, sem idêntica preocupação com a pesquisa e a produção de conhecimento (FÁVERO, 2006).

No contexto da aceleração do ritmo de desenvolvimento apoiado na industrialização, ao lado de transformações que ocorriam, tanto no campo econômico quanto no sociocultural, emerge a consciência da situação precária em que se encontravam as universidades no Brasil. Este debate começa a tomar consistência por ocasião da tramitação do projeto de Lei de Diretrizes e Bases da Educação Nacional (LDB), sobretudo na segunda metade dos anos de 1950, com a discussão em torno da questão escola pública versus escola privada. Limitados inicialmente ao meio acadêmico, os debates e reivindicações deixam de ser obra exclusiva de professores e estudantes para incorporarem vozes novas em uma análise crítica e sistemática da universidade no país (FÁVERO, 2006).

Ao contrário do crescimento do setor privado, o que se pretendia era a ampliação das vagas nas universidades públicas e gratuitas que associassem o ensino à pesquisa, com foco no desenvolvimento do país, aliado às classes populares na luta contra a desigualdade social no ensino superior (DURHAM, 2005).

O sistema de ensino superior continuou crescendo lentamente até 1960, época da formação da rede de universidades federais, da criação da Pontifícia Universidade Católica do Rio de Janeiro (a primeira de uma série de universidades católicas), da expansão do sistema universitário estadual paulista e do surgimento de instituições estaduais e municipais de ensino de menor porte em todas as regiões do país (SAMPAIO, 2000).

\footnotetext{
${ }^{1}$ Art. 141: "A Constituição assegura aos brasileiros e aos estrangeiros residentes no país a inviolabilidade dos direitos concernentes à vida, à liberdade, à segurança individual e à propriedade" (BRASIL, 1946a).
} 
Nesse contexto, foi proposto, pelo então Ministro da Educação, Clemente Mariani, o Projeto de Lei de Diretrizes e Bases da Educação Nacional que resultou na Lei no 4.024 de 20 de dezembro de $1961^{2}$ (BRASIL, 1961).

De acordo com Frauches (on line, s/d):

A liberdade de ensino foi a marca mais significativa da primeira LDB,
assegurando igualdade entre estabelecimentos de ensino públicos e
particulares legalmente autorizados. Abandonava-se a expressão
"universidade livre" ou "faculdade livre" para designar as instituições
privadas de ensino superior. (FRAUCHES (on line, s/d)

Pela primeira vez, uma lei disciplinou a organização e o funcionamento do ensino brasileiro em todos os níveis, incluindo a estruturação da educação primária e o estabelecimento de um currículo básico para a educação em todos os níveis, para todo o território nacional, preconizados e organizados pelo Conselho Federal de Educação ${ }^{3}$ (CFE) (FRAUCHES, 2007).

O parecer CFE no 977/65 (BRASIL, 1965), homologado pelo Ministro da Educação, em 6 de janeiro de 1966, passou a conceituar e a normatizar os cursos de pós-graduação no Brasil, ancorados na criação da Coordenação de Aperfeiçoamento de Pessoal de Nível Superior (CAPES) e do Conselho Nacional de Desenvolvimento Científico e Tecnológico (CNPq). Pelo Decreto-Lei nำ464, de 11 de fevereiro 1969 (BRASIL, 1969), art. 36, a CAPES e o CNPq deveriam promover a "formação e o aperfeiçoamento do pessoal docente de ensino superior" e compor, para tanto, uma política nacional e regional definida pelo CFE (CURY, 2005). O parecer diferenciava os objetivos da pós-graduação stricto sensu, dos da especialização lato sensu e acenava, ainda, para a realização de estudos de pósdoutorado em outros países (UNIFESP, 2013).

No início de 1968, a democratização estudantil, caracterizada por intensos debates dentro das universidades e pelas manifestações de rua, exigiria do governo medidas no sentido de buscar "soluções para os problemas educacionais mais agudos, principalmente dos excedentes" (FÁVERO, 2006). Nesse sentido, o

\footnotetext{
${ }^{2}$ Lei no 4.024 de 20 de dezembro de 1961, fixa as Diretrizes e Bases da Educação Nacional, modificada por emendas e artigos, reformada pelas leis 5.540/68, 5.692/71 e pela 9.394/96 (DEMO, 2002).

${ }^{3}$ O Conselho Federal de Educação (CFE) é instituído pela Lei n.. 4.024, de 20 de dezembro de 1961, em substituição ao Conselho Nacional de Educação (CNE), criado em 1931.
} 
Congresso Nacional aprovou a Reforma Universitária, pela Lei $n^{\circ} 5.540$, de 28 de novembro de 1968 (BRASIL, 1968) e fixou as normas de organização e funcionamento do ensino superior pela Lei $\mathrm{n}^{\circ}$ 5.692, de 11 de agosto de 1971 (BRASIL, 1971), de 11 de agosto de 1971 (FRAUCHES, 2007).

A reforma preconizava a extinção da cátedra; o fim da autonomia das faculdades; a criação de institutos, faculdades e/ou escolas; a introdução do sistema de créditos; a instituição de um ciclo básico, antes da formação profissional; a garantia da representação discente e docente; o ingresso contínuo por carreiras; e currículos mínimos, fixados pelo Ministério da Educação (MEC) (DURHAM, 2005).

Os anos 1970 são descritos como uma época de crescimento econômico, rotulada de "década do Milagre Brasileiro". A classe média brasileira foi beneficiada com o aumento da demanda no ensino superior, amparada pelos recursos federais, destinados à educação (DURHAM, 2005). Existia a convicção de que o país precisava de técnicos para impulsionar o desenvolvimento econômico (CASTRO, 2003), o que ocorreu com a criação de novos cursos e carreiras que não possuíam regulamentação. Essa expansão teve reflexos mais sérios, na década de 1970, quando o crescimento do ensino superior se encontrava ainda desordenado e não havia subordinação, diante dos órgãos governamentais (SOUZA, 2005).

Em 1971, a Lei no 5.692 de 11 de agosto, além de promover alterações na estrutura organizacional da educação nacional, ordenou os períodos, séries, faixas ou etapas a serem vencidas pelos alunos, para completar seus estudos em todos os graus de ensino (FRAUCHES, 2007). De acordo com o texto da Lei, o currículo tinha como pressuposto, proporcionar ao aluno a formação necessária ao desenvolvimento de sua potencialidade como elemento de autorrealização, qualificação para o trabalho e preparo para o exercício consciente da cidadania (BRASIL, 1971).

A década de 1980 foi de crise econômica e de transição política, caracterizada pelo longo e gradual processo de redemocratização (DURHAM, 2005). Com o declínio da repressão política, passou-se para a eleição de um presidente civil pelo Congresso em 1985, a Constituição de 1988 (BRASIL, 1988) e, no ano seguinte, a eleição direta para presidente. 
A Constituição Federal estabeleceu um mínimo de $18 \%$, da receita anual resultante de impostos da União, para a manutenção e o desenvolvimento do ensino. Assegurou a gratuidade do ensino público, nos estabelecimentos oficiais, em todos os níveis e criou o Regime Jurídico Único que estabelecia o pagamento igual para as mesmas funções e aposentadoria integral para funcionários federais. Em seu artigo $207^{\circ}$, reafirmou a indissociabilidade das atividades de ensino, pesquisa e extensão em nível universitário, bem como a autonomia das universidades (SOARES, 2002).

No interior das instituições, períodos de tensões e acirramentos deram origem à Associação Nacional dos Docentes Universitários (ANDES), fundada em 1981, que visava o resgate das lutas pela democratização da educação superior. Os temas prioritários eram a autonomia e a democratização, traduzidas em participação de docentes e de discentes na gestão da universidade, por meio de mecanismos de representação (SANTOS e CERQUEIRA, 2009).

O setor privado ampliou o tamanho de seus estabelecimentos por processos de fusão e incorporação de estabelecimentos menores, a fim de fugir do controle do CFE. Entre 1985 e 1990, aumentou, em 145\%, o número de instituições privadas que passaram de 20 para 49 (DURHAM, 2005).

O governo de Fernando Henrique Cardoso (FHC), a partir do seu primeiro mandato (1995-1998), deu início a uma ampla reforma que objetivou modificar o panorama da educação no país, particularmente da educação superior (CATANI e OLIVEIRA, 2002).

A nova LDB, Lei no 9.394 de 20 de dezembro de 1996 (BRASIL, 1996), estabeleceu as diretrizes e bases da educação nacional, com a relatoria do então Senador Darcy Ribeiro. Essa lei se institucionaliza em meio às mudanças sociopolítico econômicas por que passava o país e se constituiu em um marco de referência para o início do processo de reestruturação da educação superior no Brasil (FRAUCHES, 2007). 
A nova LDB inovou em todos os níveis educacionais e definiu, como universidade, a instituição que articulasse ensino e pesquisa. Fixou a obrigatoriedade do recredenciamento das instituições de ensino superior, precedida de avaliações; e estabeleceu a necessidade de renovação periódica para o reconhecimento dos cursos superiores (CURI, 2011). Se para as instituições públicas pouco ou nada afetou a implantação da nova Lei, para o setor privado representou uma ameaça de perda de status e autonomia (DURHAM, 2005).

Essa nova LDB recepcionou duas leis anteriores: a Lei $\mathrm{n} \cong$ 9.131, de 24 de novembro de 1995 que altera os dispositivos da Lei 4.024, de 1961, e cria o CNE, em substituição ao CFE, bem como estabelece avaliações periódicas das Instituições de Ensino Superior (IES) e dos cursos superiores, com a inclusão dos exames nacionais de cursos (provão); e a Lei no 9.192, de 21 de dezembro de 1995, que estabelece normas para o processo de escolha dos dirigentes das IES tanto públicas como particulares. (FRAUCHES, 2007).

Com a extinção do CFE e a criação do CNE, o MEC adquiriu maior autonomia na condução do processo de expansão do ensino superior, uma vez que assumiu funções deliberativas, até então, de competência do CFE (IPEA, 2003). O objetivo principal, dessa iniciativa, foi o de expandir a oferta de vagas sem, no entanto, ampliar a participação da rede federal e, consequentemente, dos gastos da União. Para tanto, foram agilizados e facilitados os processos de reconhecimento/ credenciamento de cursos e instituições do setor privado por parte do CNE (IPEA, 2003).

Com essa orientação do governo federal para o setor privado, o MEC passou a investir em avaliação, com a intenção de dispor de mecanismos e instrumentos que permitissem monitorar a qualidade dos cursos oferecidos (IPEA, 2003). Com esse fim, foram instituídos o Exame Nacional de Cursos (ENC), com a intenção de ser um dos elementos de avaliação dos cursos de graduação, oferecidos no Brasil e a Avaliação das Condições de Oferta dos Cursos de Graduação, denominada Avaliação das Condições de Ensino (ACE), por meio de visitas de comissões externas às instituições de ensino. 
Ainda a partir da nova LDB, mudanças contribuíram para o aumento, significativo, de instituições de caráter privado. A Lei permitiu a criação de diferentes tipos de IES quanto à organização acadêmica ${ }^{4}$, além de tornar obrigatório o credenciamento e recredenciamento das instituições que deveriam se submeter a um processo de avaliação periódico (configurado pelo Exame Nacional de Cursos, o Provão) (FRAUCHES, 2007).

A reformulação dos currículos, dos diversos cursos de formação superior, está de acordo com a flexibilização e a racionalização dos recursos para a educação (BRASIL, 1996). As instituições não são mais obrigadas a obedecerem a um currículo mínimo, justificado pela demanda de formação de profissionais que acompanhassem a evolução dos conhecimentos; pelas novas exigências que se colocam para cada área do saber; e pela enorme diversidade de instituições de ensino superior no Brasil.

No artigo $53^{\circ}$, inciso II, é facultado, às instituições de ensino superior, fixar os currículos dos seus cursos e programas, desde que observadas as diretrizes gerais fixadas pelo MEC (BRASIL, 1996). Dessa maneira, as instituições de ensino superior poderiam montar os cursos como achassem mais adequado, abrindo a possibilidade de criação de cursos de graduação mais curtos.

Em dezembro de 1997, o MEC, por meio do Edital nํ 4/97 (BRASIL, 1997), convocou as IES a apresentarem propostas para as novas Diretrizes Curriculares dos cursos superiores, a serem elaboradas pelas Comissões de Especialistas da Secretaria de Educação Superior (SESu), atendendo ao inciso II, do artigo $53^{\circ}$, da Lei de Diretrizes e Bases da Educação, bem como ao disposto na Lei nำ 9.131, de 24 de novembro de $1995^{5}$, (STELLA e CAMPOS, 2006).

\footnotetext{
${ }^{4}$ O Decreto no 2.207, de 15 de abril de 1997, o Decreto № 2.306, de 19 de agosto de 1997 e o Decreto no 3.860, de 9 de julho de 2001 classificavam as instituições de ensino superior, quanto à organização acadêmica, em universidades, centros universitários, faculdades integradas, faculdades; institutos superiores ou escolas superiores. Cada decreto foi revogando o anterior e, em 9 de maio de 2006, foi aprovado o Decreto o 5.773 (BRASIL, 2006b) que revogou o último Decreto no 3.860/01 e passou a classificar as IES em faculdades, centros universitários e universidades.

${ }^{5}$ Determinava como atribuição da Câmara de Educação Superior do Conselho Nacional de Educação a deliberação sobre as Diretrizes Curriculares dos cursos de graduação propostas com o auxílio das Comissões de Especialistas
} 
De acordo com Stella (2007), o edital era democrático e inovador e permitia a flexibilização dos currículos plenos que serviam de referência para os programas de formação. Privilegiava a indicação de áreas do conhecimento (e não de disciplinas com cargas horárias definidas, com vistas a romper com a fragmentação dos conteúdos e a especialização precoce) e perfis orientados pelas demandas da sociedade, mais adequados, portanto às necessidades da população.

As disposições básicas do edital esclareciam que o objetivo das diretrizes era servir de referência para as IES, na organização de seus programas de formação; permitir a flexibilidade, na construção dos currículos plenos; e privilegiar a indicação de áreas do conhecimento a serem consideradas. Os conteúdos a serem definidos, nas diretrizes, deveriam ter relação causal com o perfil de competências e habilidades do profissional desejado para cada área/curso (STELLA e CAMPOS, 2006).

Conforme a proposta, as diretrizes deveriam conter: o perfil desejado para o formando; as competências e as habilidades correspondentes; os conteúdos curriculares básicos e profissionais, essenciais ao desenvolvimento das mesmas competências e habilidades; a estruturação modular dos currículos; e a adoção de metodologias de ensino e de avaliação abrangentes (BRASIL, 1997).

No primeiro período do governo de Luís Inácio Lula da Silva (2003-2007), o Ministério da Educação instituiu um Grupo de Trabalho Interministerial (GTI), por meio do Decreto de 20 de outubro de 2003, encarregado de analisar a realidade e de apresentar um plano de ação que visasse à reestruturação, ao desenvolvimento e à democratização das Instituições Federais de Ensino Superior (IFES) (BRASIL, 2003c).

Esse GTI promoveu debates e, em agosto de 2003, foi realizado o Seminário "Universidade: por que e como reformar". Em novembro do mesmo ano, foi realizado um outro seminário denominado "Seminário Internacional Universidade XXI - Novos Caminhos para a Educação Superior: o Futuro em Debate" (NOGUEIRA, 2012). A partir de então, iniciou-se uma grande expansão do ensino superior público no Brasil, ao qual a Universidade Federal de São Paulo aderiu, transformando-se em uma universidade plena e multicampi. 
Além da expansão da graduação e da pós-graduação nas IFES, o governo federal instituiu também o Programa Universidade para Todos (ProUni). O ProUni foi transformado em Lei no 11.096, de 13 de janeiro de 2005 (BRASIL, 2005). Em linhas gerais, esse programa tinha, como finalidade, a concessão de bolsas de estudo integrais e parciais em cursos de graduação e sequenciais de formação específica, em instituições de ensino superior privadas. Em contrapartida, as instituições, que aderissem ao programa, teriam isenção de tributos (BRASIL, 2005).

Outro marco dessa fase, foi a criação do Sistema Nacional de Avaliação da Educação Superior (SINAES) que substituiu o Provão. O SINAES foi instituído pela Lei ำ 10.861 , de 14 de abril de 2004, com o objetivo de conduzir o processo de avaliação da educação superior, assentado no tripé: avaliação das instituições de ensino superior; dos cursos de graduação; e do desempenho dos estudantes (BRASIL, 2004b).

A Portaria do MEC o 2.051, de 9 de julho de 2004 (BRASIL, 2004c), que regulamentou os procedimentos de avaliação, permitiu que, por intemédio do SINAES, as instituições de educação superior seriam credenciadas e reconhecidas; obteriam autorização e reconhecimento para o oferecimento dos seus cursos de graduação; além da renovação periódica da oferta desses cursos, conforme o art. no 32 (BRASIL, 2004b). O governo fortaleceu, dessa maneira, os mecanismos de controle sobre as instituições de educação superior e favoreceu a regulação das ações de vários órgãos que desenvolveram as políticas públicas e privadas.

Nesta dissertação, focalizou-se a expansão da graduação no sistema público federal de ensino superior, especificamente na Universidade Federal de São Paulo. Optou-se por fixar o período de 2003 a 2012 para análise: 2003, por ser o início dessa discussão, em nível nacional e 2012, por ter sido o último ano de vigência do Programa de Apoio a Planos de Reestruturação e Expansão das Universidades Federais (REUNI).

Diante da diversidade desse processo de expansão do ensino superior nas IFES e a necessidade de conhecer e mapear essa expansão na UNIFESP, foram levantadas as seguintes questões de pesquisa:

1. Como se deu a expansão das IFES no período de 2003 a 2007 ?

2. O que significou o REUNI para a expansão das IFES? 
3. Como estava a UNIFESP na fase inicial dessa expansão nacional do ensino superior público?

4. Como a UNIFESP aderiu a esse movimento de expansão, no período de 2003 a $2012 ?$

5. O que significou essa expansão em relação aos indicadores quantitativos da graduação na instituição? 
2 OBJETIVOS 


\section{OBJETIVOS}

\subsection{Geral}

Analisar o processo de expansão da graduação da Universidade Federal de São Paulo no período de 2003 a 2012.

\subsection{Específicos}

Caracterizar a expansão nacional das Instituições Federais de Ensino Superior no período de 2003 a 2012;

Conhecer o significado do Programa de Apoio a Planos de Restruturação e Expansão das Universidades Federais para a expansão das Instituições Federais de Ensino Superior;

Descrever a expansão da Universidade Federal de São Paulo desde sua adesão ao processo nacional até o ano de 2012;

Analisar a expansão da Universidade Federal de São Paulo em relação aos indicadores quantitativos da graduação. 


\section{PERCURSO METOdOLÓGICO}

\subsection{Fundamentação metodológica}

Para alcançar os objetivos propostos, realizou-se uma pesquisa de caráter descritivo analítico com análise documental, tipo estudo de caso.

Estudo de caso comporta em um aprofundamento de um ou poucos objetos de maneira que se permita o seu amplo e detalhado conhecimento (LAKATOS; MARCONI, 2003; MINAYO, 2010).

Yin (2010) afirma que para se definir o método a ser usado é preciso analisar as questões que são colocadas pela investigação. De modo específico, este método é adequado para responder o "como?" e o ""porquê?" que são questões explicativas e tratam de relações operacionais que ocorrem ao longo do tempo, mais do que frequências ou incidências. O estudo de caso é uma estratégia de pesquisa que busca examinar um fenômeno contemporâneo dentro de seu contexto. Para Yin (2010) o objetivo do estudo de caso é explorar, descrever ou explicar.

Tal recurso envolve uma abordagem metodológica adequada quando procuramos compreender, explorar ou descrever acontecimentos e contextos complexos, nos quais estão simultaneamente envolvidos diversos fatores (ARAÚJO et al., 2008).

Ponte (2006) considera que o estudo de caso é uma investigação que se debruça sobre uma situação específica, procurando descobrir o que há nela de mais essencial e característico e, desse modo, contribuir para a compreensão global de certo fenômeno de interesse.

Essa metodologia se caracteriza pelo estudo profundo e exaustivo de um ou poucos objetos, de maneira a permitir conhecimento amplo e detalhado do mesmo (GIL, 1999).

De acordo com Guba e Lincoln (1994), o objetivo é relatar os fatos como sucederam, descrever situações ou fatos, proporcionar conhecimento acerca do fenômeno estudado e comprovar ou contrastar efeitos e relações presentes no caso. Por seu lado, Ponte (2006) afirma que o objetivo é descrever e analisar. A estes 
dois, Merriam (1998) acrescenta um terceiro objetivo, avaliar. De forma a sistematizar estes vários objetivos, Gomez, Flores e Jimenez (1996), referem que o objetivo geral de um estudo de caso é: "explorar descrever, explicar, avaliar e/ou transformar".

\subsection{Coleta de dados}

Os dados foram produzidos por meio de uma pesquisa documental que, de acordo com Gil (2002, p.45), "vale-se de materiais que não recebem ainda um tratamento analítico ou que ainda podem ser reelaborados de acordo com os objetos da pesquisa".

Para Lüdke e André (1986), a pesquisa documental é uma importante técnica utilizada para complementar informações de pesquisa, obtidas por meio de outros instrumentos na abordagem qualitativa ou então, para indicar novas dimensões do tema. Ferrari (1982) explica que pesquisa documental tem a finalidade de reunir, classificar e distribuir os documentos de todo gênero.

Documentos podem ser entendidos como quaisquer materiais escritos que possam ser usados como fonte de informação, incluindo desde leis e regulamentos, normas, pareceres, cartas, memorandos, diários pessoais, autobiografias, jornais, revistas, discursos, roteiros de programas de rádio e televisão até livros, estatísticas e arquivos escolares (LÜDKE e ANDRÉ, 1986).

Calado e Ferreira (2004, p.3), consideram que

Os documentos são fontes de dados brutos para o investigador e a sua análise implica um conjunto de transformações, operações e verificações realizadas a partir dos mesmos com a finalidade de se lhes ser atribuído um significado relevante em relação a um problema de investigação.

De acordo com Bravo (1991), são documentos todas as realizações produzidas pelo homem que se mostram como indícios de sua ação e que podem revelar suas ideias, opiniões e formas de atuar e viver. Nessa concepção, é possível apontar vários tipos de documentos: os escritos, numéricos ou estatísticos, os de reprodução de som e imagem e os documentos-objeto. 
Para Cellard (2008, p. 298), "uma pessoa que deseja empreender uma pesquisa documental deve, com o objetivo de constituir um corpus satisfatório, esgotar todas as pistas capazes de lhe fornecer informações interessantes".

A realização de um estudo de documentos deve levar em consideração o ponto de vista de quem os produziu, o que requer cuidado, por parte do pesquisador, para não comprometer a validade do seu estudo. Dessa maneira, o pesquisador fornecerá uma interpretação coerente, com a observação da temática ou do questionamento inicial.

Os documentos incluídos nesta pesquisa foram: publicações oficiais (12 documentos), legislações (4), atas das reuniões do Conselho Universitário da UNIFESP no período de 2003 a 2012 (141), publicações de gestão da UNIFESP (08) e editais de concursos vestibulares da UNIFESP (05).

Nos meses de fevereiro e março de 2016, realizamos uma busca livre na internet de dissertações e teses publicadas desde 2003 que abordassem o tema "expansão do ensino superior no Brasil". A leitura minuciosa das 12 dissertações e 2 teses encontradas nos permitiu identificar publicações oficiais e legislação referentes ao tema.

As publicações oficiais utilizadas nesta pesquisa foram:

1. ASSOCIAÇÃO NACIONAL DOS DIRIGENTES DAS INSTITUIÇÕES FEDERAIS DE ENSINO SUPERIOR. Consolidação dos dados acadêmicos, orçamentários e de pessoal referentes aos acordos de metas do Programa de Apoio a Planos de Reestruturação das Universidades - REUNI. [Relatório de Consultoria de Maria leda Costa Diniz]. Brasília (DF). Outubro de 2009.

2. ASSOCIAÇÃO NACIONAL DOS DIRIGENTES DAS INSTITUIÇÕES FEDERAIS DE ENSINO SUPERIOR. Reforma Universitária: proposta da Andifes para a reestruturação da Educação Superior no Brasil. Maio de 2004.

3. ASSOCIAÇÃO NACIONAL DOS DIRIGENTES DAS INSTITUIÇÕES FEDERAIS DE ENSINO SUPERIOR. Relatório de Acompanhamento do Programa de Apoio a Planos de Reestruturação e Expansão das Universidades Federais - REUNI. Brasília (DF): ANDIFES, jan. 2010. 
4. BRASIL. Grupo de trabalho interministerial. Bases para o enfrentamento da crise emergencial das universidades federais e roteiro para a reforma universitária brasileira. Brasília: [s.n.], 15 de dezembro de 2003a.

5. BRASIL. Ministério da Educação. A democratização e expansão da educação superior no país 2003 - 2014. Balanço das principais políticas e programas. 2015[?].

6. BRASIL. Ministério da Educação. Análise sobre a Expansão das Universidades Federais 2003 a 2012. Brasília, 2012b.

7. BRASIL. Ministério da Educação. Expansão das Universidades Federais, o sonho se torna realidade! Coordenação geral: Maria leda Costa Diniz. Brasília. 2006a.

8. BRASIL. Ministério da Educação. O Plano de Desenvolvimento da Educação. Razões, Princípios e Programas. Brasília, 24 de abril de 2007a.

9. BRASIL. Ministério da Educação. Programa de Apoio a Planos de Reestruturação e Expansão das Universidades Federais. Reuni 2008 Relatório de Primeiro Ano. Brasília (DF), 30 de outubro de 2009.

10. BRASIL. Ministério da Educação. Reforma da Educação Superior. Documento II. Reafirmando princípios e consolidando diretrizes da Reforma da Educação Superior. Brasília, 2 de agosto de 2004a.

11. BRASIL. Ministério da Educação. Relatório da Comissão Constituída pela Portaria no 126/2012, sobre a Análise sobre a Expansão das Universidades Federais 2003 a 2012. Brasília, 2012a.

12. UNIVERSIDADE FEDERAL DE SÃO PAULO. Programa de Apoio a Planos de Reestruturação e Expansão das Universidades Federais (REUNI) - Proposta de adesão.

A legislação utilizada foi:

1. BRASIL. Lei $n^{\circ} 10.172$, de 9 de janeiro de 2001a. Aprova o Plano Nacional de Educação e dá outras providências. Diário Oficial da União, Brasília, DF, 10 jan. 2001a. PNE - 2001-2010. 
2. BRASIL. Ministério da Educação. Projeto de Lei n० 7.200 , de 12 junho de 2006c. Estabelece normas gerais da educação superior, regula a educação superior no sistema federal de ensino.

3. BRASIL. Decreto $n^{\circ}$ 6.096, de 24 de abril de 2007b. Institui o Programa de Apoio a Planos de Reestruturação e Expansão das Universidades Federais - REUNI. Presidência da República. Brasília, DF: Diário Oficial da União de 25.04.2007.

4. BRASIL. Portaria no 552 SESu/MEC, de 25 de junho de 2007c: Diretrizes Gerais do Programa de Apoio a Planos de Reestruturação e Expansão das Universidades Federais - REUNI. GRUPO ASSESSOR. Brasília, DF: MEC; Secretaria da Educação Superior, 2007.

Nos meses de janeiro a junho de 2017, acessamos o portal da UNIFESP na internet em busca de publicações e documentos da instituição relacionadas ao tema. Encontramos atas, publicações de gestão e editais de vestibular.

Dentre as atas das reuniões do Conselho Universitário da UNIFESP ocorridas entre 2003 e 2012, selecionamos 52 que continham registros de informes e discussões sobre a expansão e o REUNI.

Das publicações de gestão da UNIFESP, oito integraram o conjunto de documentos analisados. São eles:

1. UNIVERSIDADE FEDERAL DE SÃO PAULO. Relatório de Gestão de 2003, de novembro de 2003;

2. UNIVERSIDADE FEDERAL DE SÃO PAULO. Relatório de Gestão de 2004, de novembro de 2004.

3. UNIVERSIDADE FEDERAL DE SÃO PAULO. Relatório de Gestão de 2005, de novembro de 2005.

4. UNIVERSIDADE FEDERAL DE SÃO PAULO. Relatório de Gestão de 2006, de novembro de 2006.

5. UNIVERSIDADE FEDERAL DE SÃO PAULO. Relatório de Gestão de 2007, de novembro de 2007. 
6. UNIVERSIDADE FEDERAL DE SÃO PAULO. Programa de Apoio a Planos de Reestruturação e Expansão das Universidades Federais (REUNI) - Proposta de adesão;

7. UNIVERSIDADE FEDERAL DE SÃO PAULO. Balanço do Primeiro ano do REUNI da UNIFESP, de 31 de outubro de 2009.

8. UNIVERSIDADE FEDERAL DE SÃO PAULO. Plano de Desenvolvimento Institucional (PDI) 2005-2010. São Paulo, SP, dezembro de 2009.

Os editais dos concursos vestibulares da UNIFESP do período de 2008 a 2012 também foram utilizados:

1. UNIVERSIDADE FEDERAL DE SÃO PAULO, Edital de retificação do Concurso Vestibular. UNIFESP 2008, 4 de setembro de 2007.

2. UNIVERSIDADE FEDERAL DE SÃO PAULO, Edital Concurso Vestibular UNIFESP 2009, 3 de setembro de 2008.

3. UNIVERSIDADE FEDERAL DE SÃO PAULO, Edital Concurso Vestibular UNIFESP 2010, 7 de julho de 2009.

4. UNIVERSIDADE FEDERAL DE SÃO PAULO, Edital Concurso Vestibular UNIFESP 2011, 24 de agosto de 2010.

5. UNIVERSIDADE FEDERAL DE SÃO PAULO, Edital Concurso Vestibular UNIFESP 2012, 5 de setembro de 2012.

\subsection{Análise de dados}

Realizada a seleção dos documentos, procedemos à análise dos dados, com o intuito de produzir ou reelaborar conhecimentos e criar novas formas de compreender a expansão da graduação na UNIFESP.

Cellard (2008, p. 303) afirma que este "é o momento de reunir todas as partes - elementos da problemática ou do quadro teórico, contexto, autores, interesses, confiabilidade, natureza do texto, conceitos chave". Para Minayo (2007), a análise dos dados de uma pesquisa percorre o estabelecimento de uma compreensão dos dados, possibilita a confirmação ou não de pressupostos da pesquisa e amplia o 
conhecimento dos assuntos relacionados ao estudo, permitindo uma articulação ao contexto do qual faz parte.

Os dados coletados foram analisados por meio da técnica de análise de conteúdo, modalidade temática, segundo Franco (2012).

A escolha dessa estratégia para análise justifica-se por esta ser a técnica mais elaborada e de maior prestígio no campo da observação documental e constituir-se como meio para estudar as comunicações entre os homens enfatizando o conteúdo das mensagens por eles emitidas (BRAVO, 1991; TRIVIÑOS, 1987). Godoy (1995), afirma que a análise de conteúdo consiste em uma técnica metodológica que se pode aplicar em discursos diversos e a todas as formas de comunicação, seja qual for à natureza do seu suporte.

Para Bardin (2009), o termo análise de conteúdo designa:

um conjunto de técnicas de análise das comunicações visando a obter, por procedimentos sistemáticos e objetivos de descrição do conteúdo das mensagens, indicadores (quantitativos ou não) que permitam a inferência de conhecimentos relativos às condições de produção/recepção (variáveis inferidas) destas mensagens (p. 47).

Para Franco (2012, p. 12) "o ponto de partida da análise de conteúdo é a mensagem, seja ela verbal (oral ou escrita), gestual, silenciosa, figurativa, documental ou diretamente provocada". "A análise de conteúdo é uma técnica de pesquisa cujo objetivo é a busca do sentido ou dos sentidos de um texto" (p.11).

Inicialmente, identificamos e codificamos todos os documentos selecionados e os organizamos em ordem cronológica. Em seguida, realizamos uma leitura flutuante dos documentos selecionados para nos familiarizarmos com os mesmos. Consideramos esta uma fase de pré-análise.

A análise propriamente dita se deu com a leitura aprofundada dos documentos e identificação de 132 Unidades de Contexto (UC):

A Unidade de Contexto é a parte mais ampla do conteúdo a ser analisado, porém é indispensável para a necessária análise e interpretação dos textos a serem decodificados (tanto do ponto de vista do emissor, quanto do receptor) e, principalmente, para que se possa estabelecer a necessária diferenciação resultante dos conceitos de "significado" e de "sentido" os quais devem ser consistentemente respeitados, quando da análise e interpretação das mensagens disponíveis. (FRANCO, 2012, p. 43) 
Das UC, identificamos 341 Unidades de Registro (UR), das quais emergiram categorias e subcategorias. Segundo Franco (2012), a UR é uma asserção sobre determinado assunto, configurando-se como a menor parte do conteúdo. Sua ocorrência é registrada de acordo com as categorias levantadas. Ela pode ser uma simples sentença (sujeito e predicado), um conjunto delas ou um parágrafo. A figura 1 apresenta sucintamente as etapas da análise de dados.

Figura 1. Etapas da análise de dados da pesquisa

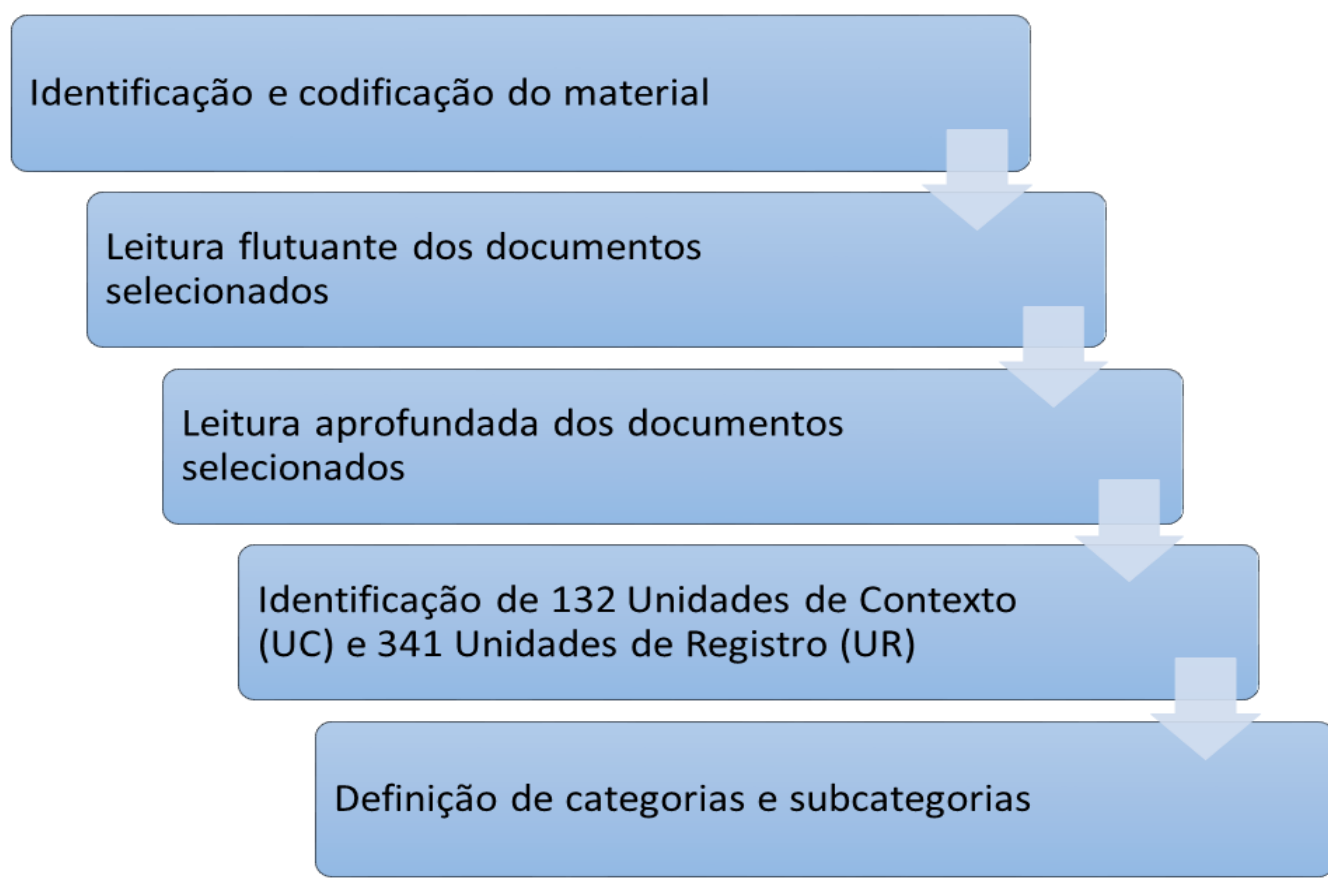

Fonte: Figura elaborada pela autora.

\subsection{Procedimentos éticos}

Esta pesquisa recebeu autorização para ser desenvolvida pelo Comitê de Ética em Pesquisa da Universidade Federal de São Paulo (UNIFESP), atendendo às normas da Resolução o 466 de 08 de dezembro de 2012, do Conselho Nacional de Saúde e recebeu aprovação mediante parecer № 7720261115, de 8 de dezembro de 2015 (ANEXO 1). 


\section{RESULTADOS E DISCUSSÃO}

Os dados, obtidos a partir da pesquisa documental, foram agrupados em três subcapítulos: 1) A primeira fase do processo de expansão; 2) O REUNI na expansão das IFES; e 3) A expansão na UNIFESP.

Em cada subcapítulo, foram apresentadas questões específicas que nortearam a pesquisa, os documentos examinados e as categorias e subcategorias que emergiram da análise temática dos documentos.

No primeiro subcapítulo, pretendeu-se traçar um panorama geral da educação superior no Brasil e identificar os marcos nacionais desse início de expansão das IFES e as transformações ocorridas no período de 2003 a 2007. Um aspecto analisado foi a interiorização da oferta de educação superior, considerada essencial no combate ao desequilíbrio do desenvolvimento regional e para atingir estudantes sem condições de se deslocar para outras regiões.

No segundo subcapítulo, fez-se a análise do REUNI na expansão das IFES. Para este estudo, partiu-se de uma questão geral e de outras específicas. A questão geral consistiu em "Como se deu a expansão das IFES a partir do REUNI?" e as questões específicas foram "Qual o panorama da educação superior no Brasil no momento em que foi instituído o REUNI?"; "Quais as diretrizes, objetivos, dimensões e metas definidas para adesão ao REUNI?"; e "Quais foram os resultados dessa fase de expansão?"

No terceiro subcapítulo, analisou-se, especificamente, a expansão na UNIFESP. Como questões de pesquisa elegeu-se: "Como estava a UNIFESP na fase inicial da expansão nacional do ensino superior público?"; "Como a UNIFESP aderiu a esse movimento de expansão no período de 2003 a 2012?"; e "O que significou essa expansão em relação aos indicadores quantitativos da graduação?"

\subsection{A primeira fase do processo de expansão (2003 - 2007)}

Com a finalidade de entender a primeira etapa de expansão das IFES, elegeu-se algumas questões específicas, tais como: "Qual o panorama da educação superior no momento em que se iniciou a expansão das IFES?"; "Quais os primeiros 
documentos / legislação que a sustentaram?"; "Quais os motivos apontados para essa expansão?”; “Quais as metas definidas nesta primeira etapa?”; e "Quais foram os resultados desse movimento inicial de expansão?"

\subsubsection{O panorama da educação superior no momento em que se iniciou a expansão das IFES}

Para o entendimento desse panorama, nesse momento histórico, os seguintes documentos foram analisados:

a) BRASIL. Lei $n^{\circ}$ 10.172, de 9 de janeiro de 2001a. Aprova o Plano Nacional de Educação e dá outras providências. Diário Oficial da União, Brasília, DF, 10 jan. 2001a. PNE - 2001-2010.

b) BRASIL. Grupo de trabalho interministerial. Bases para o enfrentamento da crise emergencial das universidades federais e roteiro para a reforma universitária brasileira. Brasília: [s.n.], 15 de dezembro de 2003a.

c) ASSOCIAÇÃO NACIONAL DOS DIRIGENTES DAS INSTITUIÇÕES FEDERAIS DE ENSINO SUPERIOR. Reforma Universitária: proposta da Andifes para a reestruturação da Educação Superior no Brasil. Maio de 2004.

d) BRASIL. Ministério da Educação. Reforma da Educação Superior. Documento II. Reafirmando princípios e consolidando diretrizes da Reforma da Educação Superior. Brasília, 2 de agosto de 2004a.

e) BRASIL. Ministério da Educação. Projeto de Lei n 7.200, de 12 junho de 2006. Estabelece normas gerais da educação superior, regula a educação superior no sistema federal de ensino. 2006c.

f) BRASIL. Ministério da Educação. O Plano de Desenvolvimento da Educação. Razões, Princípios e Programas. Brasília, 24 de abril de $2007 a$.

g) BRASIL. Ministério da Educação. Análise sobre a Expansão das Universidades Federais 2003 a 2012. Brasília, 2012b. 
h) BRASIL. Ministério da Educação. A democratização e expansão da educação superior no país 2003 - 2014. Balanço das principais políticas e programas. 2015[?].

$\mathrm{Na}$ análise temática desses documentos, identificou-se 83 UC, com 228 UR, das quais emergiram três categorias e suas respectivas subcategorias:

\section{Constatação de crise no ensino superior}

$\checkmark$ Momento de desdobramento de crise fiscal do Estado,

$\checkmark$ Desarticulação do setor público brasileiro,

$\checkmark$ Reconhecimento da necessidade de democratização no processo de expansão da educação superior,

$\checkmark$ Educação superior como objeto de permanente atenção, por parte da sociedade, do Governo e das comunidades acadêmicas,

$\checkmark$ Expectativa de uma explosão na demanda por educação superior,

$\checkmark$ Momento de enfrentamento de problemas no ensino superior público.

\section{Reconhecimento do papel estratégico da educação superior pública}

$\checkmark$ Reconhecimento do papel relevante da educação superior pública para o desenvolvimento social e econômico do País,

$\checkmark$ Reconhecimento do papel estratégico da educação superior pública como possibilidade de maior inclusão social,

$\checkmark$ Responsabilidade da educação superior pública pela transformação da educação em âmbito nacional,

$\checkmark$ Reconhecimento da educação superior pública como referência e orientação para o sistema educacional brasileiro,

$\checkmark$ Reconhecimento do papel estratégico da universidade pública na qualificação docente no país,

$\checkmark$ Reconhecimento do papel estratégico da educação superior pública na produção e disseminação do conhecimento, bem como na geração e transferência de inovação tecnológica, articulando ensino, pesquisa e extensão, 
$\checkmark$ Reconhecimento da necessidade de maior autonomia para a educação superior pública.

\section{Necessidade de uma Reforma da Educação Superior}

$\checkmark$ Constatação da heterogeneidade da educação superior,

$\checkmark$ Reconhecimento da importância do Estado no financiamento da educação pública superior,

$\checkmark \quad$ Necessidade de elaboração de políticas mais eficazes e duradouras,

$\checkmark$ Reconhecimento do papel estratégico da execução do PDE na educação superior,

$\checkmark$ Reconhecimento do papel estratégico do Sistema Nacional de Educação Superior e necessidade de sua reformulação,

$\checkmark$ Construção de alternativas que visassem o aperfeiçoamento institucional,

$\checkmark$ Reconhecimento do papel estratégico da avaliação da educação superior,

$\checkmark$ Necessidade de medidas decisivas para evitar o colapso das universidades federais,

$\checkmark$ Estabelecimento de medidas decisivas para recompor o quadro de professores e servidores,

$\checkmark \quad$ Necessidade de medidas decisivas para financiar hospitais universitários,

$\checkmark$ Reconhecimento da importância da Educação a Distância.

A primeira categoria, que emergiu da análise documental, apontou a Constatação de crise no ensino superior no instante que antecedeu a primeira fase de expansão das IFES. Esse momento equivalia ao início de um novo governo, em que o Desdobramento da crise fiscal do Estado era uma variável importante, no que se refere a essa instabilidade. Os documentos revelavam uma preocupação com a Desarticulação do setor público brasileiro e indicaram a possibilidade de esvaziamento e degradação que ameaçavam o quadro do ensino superior público à época.

O Reconhecimento da necessidade de democratização no processo de expansão da educação superior no Brasil era enfatizado. Salientavam-se as desigualdades regionais, a má distribuição de renda e a baixa escolaridade média 
da nossa população, bem como se reconhecia o potencial de redução dessas variáveis com a interiorização da oferta da educação superior pública. Ao mesmo tempo, constatava-se uma concentração das matrículas em instituições particulares das regiões mais desenvolvidas.

Nesse panorama, a Educação superior, como objeto de permanente atenção por parte da sociedade, do Governo e das comunidades acadêmicas, era realçada e se reafirmava a necessidade de atenção à Constituição, no tocante ao compromisso da União com o ensino superior. O "Documento II da Reforma da Educação Superior (Reafirmando princípios e consolidando diretrizes da Reforma da Educação Superior)" mencionava que:

\begin{abstract}
"A Educação (...) é um elemento de transformação pessoal e de participação na cidadania, devendo ser acessível a todos, em todas as fases da vida, constituindo-se em fator de justiça social, oferecendo equidade de oportunidades a todos os cidadãos, contribuindo para a redução de desigualdades regionais, sociais e étnico-culturais" (BRASIL. MEC, 2004a)
\end{abstract}

A constatação de crise no ensino superior sinalizava para um Momento de enfrentamento de problemas no ensino superior público, com a expectativa em relação à execução do $\mathrm{PNE}$. O quadro geral era de inquietação devido à existência de poucos docentes; em razão da migração de docentes titulados para as universidades particulares; por motivo dos prejuízos no desempenho dos bolsistas e em virtude da queda na qualidade da formação de mestres e doutores.

O documento "Bases para o enfrentamento da crise emergencial das universidades federais e roteiro para a reforma universitária brasileira", elaborado pelo Grupo de Trabalho Interministerial de 2003, apontava que:

“(...) A continuação do atual quadro de emergência provocará, inevitavelmente, a tragédia do esvaziamento, degradação e desarticulação do excelente sistema montado nas universidades federais brasileiras. Esse sistema (...) enfrenta uma crise em sua própria essência. (...) exige (...) enfrentamento da emergência, medidas imediatas de reorientação rumo a uma grande reforma, que the forneça uma nova estrutura para enfrentar 0 século XXI." (BRASIL. Presidência da República, 2003a)

Concomitantemente, nesse panorama, constatava-se uma Expectativa de explosão na demanda por educação superior com o aumento do número de egressos no ensino médio e com os avanços da Educação a Distância. 
Outra categoria que surgiu, a partir dos documentos analisados, foi 0 Reconhecimento do papel estratégico da educação superior pública. Coerente com a necessidade de democratização do processo de expansão do ensino superior, os documentos enfatizavam um Reconhecimento do papel relevante da educação superior pública para o desenvolvimento social e econômico do País e evidenciavam a educação superior como um bem público e como uma condição de desenvolvimento não só humano, como econômico, social e de afirmação de valores e de identidades culturais. As IFES, bem como outras instituições públicas, eram consideradas como um referencial de qualidade para todo o sistema e contribuíam, de maneira estratégica, para o desenvolvimento do País. Nesse contexto, a educação superior pública era vista como uma possibilidade de afirmação e de consolidação de identidades culturais e de valores; como formadora de cidadãos qualificados; como elemento de transformação pessoal e de auxílio na participação da cidadania.

O Reconhecimento do papel estratégico da educação superior pública como possibilidade de maior inclusão social foi salientado, com ênfase na promoção da pluralidade, da diversidade e da possibilidade de maior mobilidade social, bem como na promoção das condições acadêmicas de estudantes egressos do ensino médio público, especialmente, afrodescendentes e indígenas. O "Documento II da Reforma da Educação Superior (Reafirmando princípios e consolidando diretrizes da Reforma da Educação Superior)" afirmava que:

"A Universidade é, também, o ambiente em que, especialmente, se reinventa a solidariedade e a partilha de saberes, promovendo a inclusão social e produzindo conhecimentos dirigidos à construção de um futuro melhor para todos." (BRASIL. MEC, 2004a)

O documento "Plano de Desenvolvimento da Educação. Razões, Princípios e Programas", comentava sobre a exclusão social por condições econômicas:

“(...) promoção de inclusão social pela educação, minorando nosso histórico de desperdício de talentos, considerando que dispomos comprovadamente de significativo contingente de jovens competentes e criativos que têm sido sistematicamente excluídos por um filtro de natureza econômica." (BRASIL. MEC, 2007a) 
Em um país como o Brasil, marcado por desigualdades sociais, a análise documental mostrou um panorama de potencial diminuição das desigualdades étnico-culturais e regionais, devido a uma valorização e expansão do ensino superior público. O "Documento II da Reforma da Educação Superior (Reafirmando princípios e consolidando diretrizes da Reforma da Educação Superior)" afirmava que:

\begin{abstract}
"Às Universidades cabe a missão de criar, desenvolver, sistematizar e difundir conhecimentos, em suas áreas de atuação, a partir da liberdade de pensamento e de opinião, tendo como meta participar e contribuir para o desenvolvimento social, econômico, cultural e científico da nação, promovendo a inclusão da diversidade étnico-cultural e a redução das desigualdades sociais e regionais do país." (BRASIL. MEC, 2004a)
\end{abstract}

Os documentos evidenciaram a Responsabilidade da educação superior pública pela transformação da educação em âmbito nacional e a mencionaram como ponto estratégico nos processos de transformação social. Nesse sentido, as universidades federais não só contribuíram, como contribuem, ativamente, para o desenvolvimento científico e tecnológico do país e para a transformação da realidade da qual faziam e ainda fazem parte.

Coerente com esse panorama, o Reconhecimento da educação superior pública como referência e orientação para o sistema educacional brasileiro sinalizava a necessidade de um novo marco legal, político, institucional e administrativo capaz de orientar e qualificar a expansão do conjunto da educação superior brasileira. Mencionou-se o documento "Reforma Universitária: proposta da Andifes para a reestruturação da Educação Superior no Brasil" que explicitava o seguinte:

\footnotetext{
"A educação superior pública, laica e gratuita, elemento motor do processo de articulação e coordenação entre os níveis de ensino, deve liderar a expansão da oferta de matrículas, constituir referência de qualidade para o conjunto do sistema educacional e atuar no combate às desigualdades sociais e regionais. Para isso, precisa se modernizar, crescer e se interiorizar." (ANDIFES, 2004)
}

O Reconhecimento do papel estratégico da universidade pública na qualificação docente no país foi mencionado na fase que precedeu o processo de expansão em estudo. Nesse contexto, no que se referia à produção científica e à formação e qualificação docente da educação superior em instituições públicas e 
privadas, os documentos afirmavam que era necessário investir na produção acadêmica, no avanço do conhecimento em todas as áreas e na formação docente, inclusive para professores da educação básica, para que se atingissem as metas previstas na Lei de Diretrizes e Bases da Educação Nacional (LDB) quanto à titulação docente.

Assim, o Reconhecimento do papel estratégico da educação superior pública na produção e disseminação do conhecimento, bem como na geração e transferência de inovação tecnológica, articulando ensino, pesquisa e extensão, era salientado, juntamente, com a produção e desenvolvimento da ciência e tecnologia, a acessibilidade dos saberes científicos, das artes e das humanidades.

De acordo com o documento "Reforma Universitária: proposta da Andifes para a reestruturação da Educação Superior no Brasil”:

\footnotetext{
"O reconhecimento do papel estratégico desempenhado pelas IFES no contexto do sistema educacional brasileiro, como um todo, deve-se traduzir em sua contínua expansão qualificada, em investimentos que garantam e aprofundem seus compromissos com o desenvolvimento científico, 0 tecnológico e cultural, com a inovação, com a formação de pesquisadores, professores e profissionais altamente qualificados." (ANDIFES, 2004)
}

Esses aspectos eram enfatizados no "Documento II da Reforma da Educação Superior (Reafirmando princípios e consolidando diretrizes da Reforma da Educação Superior)":

\begin{abstract}
"A missão central e estratégica do Sistema de Ensino Superior, tanto Público como Privado, no projeto de desenvolvimento cultural, econômico e social do país, é formar profissionais de qualidade, produzir ciência e tecnologia, assim como cooperar no entendimento do ser humano e do meio em que vive, gerando e divulgando conhecimentos culturais, científicos e técnicos." (BRASIL. MEC, 2004a)
\end{abstract}

Ainda num panorama de valorização da educação superior pública, os documentos apontavam para o Reconhecimento da necessidade de maior autonomia para a educação superior pública e ressaltavam a importância de um ponto de equilíbrio entre a soberania popular e a autonomia do fazer acadêmico (autonomia didática, universitária e didático-científica). Nesse contexto, o documento "Reforma Universitária: proposta da Andifes para a reestruturação da Educação Superior no Brasil" comentava que: 


\begin{abstract}
"Além de reivindicar uma definição clara, por parte do Governo, do montante de recursos destinados, anualmente, para a manutenção, qualificação e expansão das IFES, a autonomia demandará importantes reformulações administrativas. A autonomia não diz respeito, no entanto, somente a uma tomada de decisão no plano financeiro e jurídico. Trata- se de um processo que, além de disposição política, envolve redefinições conceituais e operacionais de grande envergadura, que incidirão, inclusive, no plano da gestão acadêmica e institucional." (ANDIFES, 2004)
\end{abstract}

É dentro desse panorama que surge a Necessidade de uma Reforma da Educação Superior. Essa categoria emergiu da análise documental e, a partir dela, foram viabilizadas as condições políticas para sua implementação. A Constatação da heterogeneidade da educação superior vigente e o Reconhecimento da valorização da qualidade da educação superior pública eram sinalizados como motivos importantes para a necessidade da reforma. Os documentos apontavam para setores da educação superior que ofereciam um ensino de qualidade duvidosa; para o risco de mercantilização da educação; para uma crescente fragilidade do controle público no reconhecimento de novos cursos e instituições; e para a ausência de processos legitimados de avaliação.

Neste contexto, a Elaboração de políticas mais eficazes e duradouras entendendo a educação superior como política de Estado e o Reconhecimento do papel estratégico do Plano de Desenvolvimento da Educação (PDE) foram realçados, juntamente com a necessidade da expansão da oferta de vagas, para evitar o baixo índice de acesso à educação superior.

Nesse cenário, reconhecia-se a importância da Construção de alternativas que visassem o aperfeiçoamento institucional, em que o MEC era o mantenedor, supervisor e regulador da expansão das IFES, por meio de um processo de formação dinâmico e articulado de ensino, pesquisa e extensão. Foram realçados o Reconhecimento do papel estratégico do Sistema Nacional de Educação Superior e necessidade de sua reformulação, bem como a construção, a formalização e a revisão de um marco legal. Nesse sentido, era importante o estabelecimento de processos e medidas decisivas para redefinir o Sistema Nacional de Avaliação, nos quais a relevância da avaliação e da regulação consistiam em partes integrantes da autonomia universitária. 
Essas medidas eram mencionadas como importantes para evitar o colapso das universidades federais e para regulamentar as ações do Estado. O documento "Bases para o enfrentamento da crise emergencial das universidades federais e roteiro para a reforma universitária brasileira" afirmava que:

\begin{abstract}
"A relação entre universidades e Estado se dará pelo Sistema Nacional de Avaliação e Progresso do Ensino Superior, que classificará as instituições e cursos conforme a qualidade que elas apresentam em suas funções acadêmicas e conforme o cumprimento de seus compromissos com a sociedade e o País." (BRASIL. Presidência da República, 2003a)
\end{abstract}

O "Documento II da Reforma da Educação Superior (Reafirmando princípios e consolidando diretrizes da Reforma da Educação Superior)", sinalizou para a importância da constituição do Sistema Nacional de Avaliação no ensino superior público:

\begin{abstract}
"A avaliação é peça fundamental da vida universitária e parte integrante e indissociável da Autonomia. É ela que permite cumprir adequadamente a missão social das Instituições de Ensino Superior. Da avaliação decorrem consequências e estas devem estar voltadas à projeção de cenários futuros para as Instituições." (BRASIL. MEC, 2004a)
\end{abstract}

Ainda nesse processo de necessidade de uma Reforma da Educação Superior no Brasil, apontava-se para a Importância do Estado no financiamento da educação pública superior. O "Documento II da Reforma da Educação Superior (Reafirmando princípios e consolidando diretrizes da Reforma da Educação Superior)" sinalizava:

\footnotetext{
"Cabe ao Estado (...) criar as condições políticas, definindo autonomia e prerrogativas correlatas, garantindo condições de financiamento e tributação, estabelecendo processos de avaliação e regulação para o adequado funcionamento do sistema." (BRASIL. MEC, 2004a)
}

Nesse contexto, o reconhecimento da necessidade de medidas emergenciais de apoio ao ensino superior público ficou evidente com a Necessidade de medidas decisivas para evitar o colapso das universidades federais. Era necessário reconhecer que a universidade pública brasileira, nos limites impostos pela educação presencial, não teria condições de aumentar as vagas, o que evidenciava o Reconhecimento da importância da Educação a Distância. O documento "Bases 
para o enfrentamento da crise emergencial das universidades federais e roteiro para a reforma universitária brasileira" explicava que:

\begin{abstract}
"Em um país de dimensões continentais a educação a distância surge como um caminho viável e necessário. Infelizmente, no Brasil, muitos ainda julgam a educação a distância um ensino de segunda categoria e prevalece um medo infundado de que a educação a distância possa ameaçar o ofício de professor, no desconhecimento de que em qualquer processo de educação a distância bem planejado exige número apreciável de professores no planejamento, elaboração de conteúdo, tutoria e avaliação. É urgente romper com essa cultura conservadora, que serve de suporte para um desinteresse político em promover investimentos públicos no apoio à disseminação do ensino a distância." (BRASIL. Presidência da República, 2003a)
\end{abstract}

Para a efetivação da reforma universitária brasileira era necessário a participação de recursos não orçamentários e o aumento da captação de recursos junto às Fundações de Apoio, o que ficou evidenciado no documento "Bases para o enfrentamento da crise emergencial das universidades federais e roteiro para a reforma universitária brasileira":

\footnotetext{
"Nos últimos anos, tem-se observado a nítida tendência a aumentar a participação de recursos não orçamentários na composição do financiamento das atividades das universidades federais (...) por meio de convênios com empresas estatais, governos estaduais e municipais (...) como de pagamentos por serviços prestados em cursos especiais, trabalhos técnicos de consultoria e prestação de serviços diversos." (...) Com esses dois instrumentos - autonomia e Fundação de Apoio - as universidades federais certamente disporiam de condições não só para aumentar a captação de recursos, mas também para gerenciar com mais eficiência e previsibilidade os recursos que conseguir captar." (BRASIL. Presidência da República, 2003a)
}

O Estabelecimento de medidas decisivas para recompor o quadro de professores e servidores era considerado. Os documentos sinalizaram que as aposentadorias precoces esvaziaram as universidades públicas em benefício das universidades privadas. Os dados mostraram que, desde 1994, as universidades federais dispunham do mesmo total de postos docentes, ou seja, 50.426 professores. Como recurso para preencher essa falta de docentes, as universidades federais utilizavam o professor substituto que, na maioria dos casos, não possuíam uma formação adequada e eram contratados em caráter provisório, sem vínculo e nem estabilidade. Em relação ao quadro de servidores, referia-se, ainda, para a necessidade de recomposição, sobretudo de reorganização. 
Outro aspecto salientado à época, era a Necessidade de medidas decisivas para financiar hospitais universitários, por meio da formulação de políticas adequadas à recuperação e à consolidação dos hospitais universitários ligados às IFES e pelo reconhecimento de sua importância para o ensino, para a pesquisa, para a gestão, bem como para a atenção à saúde.

\subsubsection{Motivos apontados, metas traçadas e primeiros documentos/legislação que sustentaram a primeira etapa de expansão das IFES}

Frente ao panorama traçado, constata-se que os primeiros documentos que delinearam o início da expansão nesse período foram:

a) BRASIL. Grupo de trabalho interministerial. Bases para o enfrentamento da crise emergencial das universidades federais e roteiro para a reforma universitária brasileira. Brasília: [s.n.], 15 de dezembro de 2003.

b) BRASIL. Ministério da Educação. Reforma da Educação Superior. Documento II. Reafirmando princípios e consolidando diretrizes da Reforma da Educação Superior. Brasília, 2 de agosto de 2004. 2004a.

Importante registrar que a Reforma da Educação Superior no período analisado, iniciou-se, oficialmente, com o Decreto de 20 de outubro de 2003 (esse decreto foi publicado sem número no DOU de 21 de outubro de 2003). O decreto instituiu o Grupo de Trabalho Interministerial (GTI), encarregado de analisar a situação de crise das universidades federais e apresentar um plano de ação, de desenvolvimento, de reforma da universidade brasileira e da democratização das Instituições Federais de Ensino Superior (IFES). O GTI foi composto por 12 membros, com dois representantes de cada um dos seguintes órgãos: Ministério da Educação; Casa Civil; Secretaria Geral da Presidência da República; Ministério do Planejamento, Orçamento e Gestão; Ministério da Ciência e Tecnologia; Ministério da Fazenda.

O relatório final do GTI foi divulgado, extraoficialmente, em dezembro de 2003 e chamado de "Bases para o enfrentamento da crise emergencial das universidades federais e roteiro para a reforma universitária brasileira". O documento sinalizou os motivos sequentes: 
$\checkmark$ Desarticulação do setor público brasileiro: crise fiscal do Estado que incidiu sobre recursos humanos, de manutenção e de investimento;

$\checkmark$ Necessidade da implementação de reforma universitária brasileira mais profunda. Autonomia universitária: autonomia financeira e autonomia de gestão financeira;

$\checkmark \quad$ Necessidade da regulamentação das relações entre as universidades e as fundações de apoio;

$\checkmark$ Necessidade da implementação de um Sistema Nacional de Avaliação da Educação Superior: Supervisão e Regulação;

$\checkmark$ Necessidade de reposição do quadro de professores: aposentadorias precoces e professores que migraram para as instituições privadas de ensino superior;

$\checkmark$ Necessidade de recomposição do quadro de funcionários Técnicos Administrativos;

$\checkmark$ Necessidade de financiamento: complementação de recursos, programa específico para recuperação predial, aquisição de equipamentos para seus laboratórios e bibliografia para o ensino de graduação;

$\checkmark$ Necessidade da interiorização/regionalização dos campi universidades federais, com a oferta de vagas e cursos nas universidades públicas;

$\checkmark$ Necessidade da garantia do acesso e permanência do estudante na universidade pública;

$\checkmark$ Necessidade da redução de desigualdades regionais, sociais e étnicoculturais;

$\checkmark \quad$ Necessidade da inclusão social: solidariedade e o respeito às diferenças;

$\checkmark$ Necessidade de um programa de educação a distância: a universidade pública brasileira, nos limites impostos pela educação presencial, não teria condições de aumentar as vagas de forma maciça no curto e médio prazo.

Como ações emergenciais, os documentos analisados apresentaram propostas e diretrizes, como nos demonstra o documento "Reafirmando princípios e consolidando diretrizes da Reforma da Educação Superior, de 2004" BRASIL, MEC. 2004a): 
$\checkmark$ Formular e implementar as diretrizes de um plano emergencial para equacionar e superar o endividamento progressivo junto aos fornecedores, combinado com a elevação dos recursos para os custos operacionais.

$\checkmark$ Abrir concursos para preencher as vagas de professores e servidores, originadas por demissões, aposentadorias e exonerações, não preenchidas ao longo dos últimos dez anos, e para substituir os professores contratados em caráter temporário por professores efetivos. Assegurar ainda recursos para cobrir os déficits em manutenção e investimento.

$\checkmark$ Outorgar autonomia para garantir às universidades federais, o uso mais racional de recursos, maior eficiência no seu gerenciamento e liberdade para captar e aplicar recursos extraorçamentários, além da autonomia didático-pedagógica.

$\checkmark$ Garantir novas vagas: 1) concedendo bolsas de aproveitamento e regionalização para a contratação de doutores que desejem se dedicar ao magistério, especialmente nas licenciaturas em física, matemática, biologia, química, nos locais carentes de pessoal com formação superior; 2) adotando critérios de regionalização e interiorização na política de abertura de vagas para concurso, juntamente com um auxílio para implantação de novas linhas de pesquisa para esses novos contratados e 3) reintegrando aposentados às atividades das universidades federais, mediante a implementação de um programa especial de bolsas de excelência.

$\checkmark$ Implementar um programa de educação a distância: a universidade pública brasileira, nos limites impostos pela educação presencial, não teria condições de aumentar as vagas de forma maciça no curto e médio prazo.

$\checkmark$ Combater desigualdades sociais e regionais, e acompanhar e supervisionar o Sistema Federal de Ensino Superior 


\subsubsection{Resultados da primeira fase da expansão das IFES}

$\mathrm{Na}$ perspectiva de responder quais foram os resultados dessa fase inicial da expansão, denominada de Expansão I, foram considerados os seguintes documentos:

a) BRASIL. Ministério da Educação. Expansão das Universidades Federais, o sonho se torna realidade! Coordenação geral: Maria leda Costa Diniz. Brasília. 2006a.

b) BRASIL. Ministério da Educação. Análise sobre a Expansão das Universidades Federais 2003 a 2012. Brasília, 2012.

c) BRASIL. Ministério da Educação. Relatório da Comissão Constituída pela Portaria no 126/2012, sobre a Análise sobre a Expansão das Universidades Federais 2003 a 2012. Brasília. 2012.

d) BRASIL. Ministério da Educação. A democratização e expansão da educação superior no país 2003 - 2014. Balanço das principais políticas e programas. 2015[?].

Até o ano de 2002, o Brasil contava com 45 Universidades Federais e 148 campi/unidades, de acordo com o documento "Análise sobre a Expansão das Universidades Federais 2003 a 2012" (BRASIL. MEC, 2012).

No período de 2003 a 2007, foram criadas dez universidades federais em regiões, prioritariamente, não metropolitanas, dentre as quais: duas (20\%) na região nordeste, quatro (40\%) na região sudeste, três (30\%) na região sul e uma (10\%) na região centro-oeste, conforme demonstra o Quadro 1: 
Quadro 1. Universidades federais criadas entre 2003 e 2007, por região

\begin{tabular}{|l|l|l|}
\hline Região & IFES & Nome da IFES \\
\hline \multirow{3}{*}{ Sordeste } & UFRB & Universidade Federal do Recôncavo da Bahia \\
\cline { 2 - 3 } & UFERSA & Universidade Federal Rural do Semiárido \\
\hline & UFABC & Fundação Universidade Federal do ABC \\
\cline { 2 - 3 } & UNIFAL-MG & Universidade Federal de Alfenas \\
\cline { 2 - 3 } & UFTM & Universidade Federal do Triângulo Mineiro \\
\cline { 2 - 3 } & UFVJM & Universidade Federal dos Vales Jequitinhonha e Mucuri \\
\hline \multirow{3}{*}{ Sul } & UFCSPA & $\begin{array}{l}\text { Fundação Universidade Federal de Ciências da Saúde } \\
\text { de Porto Alegre }\end{array}$ \\
\cline { 2 - 3 } & UNIPAMPA & Fundação Universidade Federal do Pampa \\
\cline { 2 - 3 } & UTFPR & Universidade Tecnológica Federal do Paraná \\
\hline Centro-Oeste & UFGD & Fundação Universidade Federal de Grande Dourados \\
\hline
\end{tabular}

Fonte: SIMEC/MEC.

Nesse mesmo período, foram consolidadas duas universidades federais já criadas: Universidade Federal do Vale do São Francisco (UNIVASF) e Universidade Federal do Tocantins (UFT).

De acordo com o documento "A democratização e expansão da educação superior no país 2003 - 2014. Balanço das principais políticas e programas" (BRASIL. MEC, 2015[?]) e como demonstra o Gráfico 1, nesse período foram criados 79 novos campi: 31 (39\%) na região nordeste; 16 (20\%) na região norte; $13(17 \%)$ na região sudeste; $16(20 \%)$ na região sul e $3(4 \%)$ na região centro-oeste.

Gráfico 1. Campi criados e consolidados nas IFES, por região

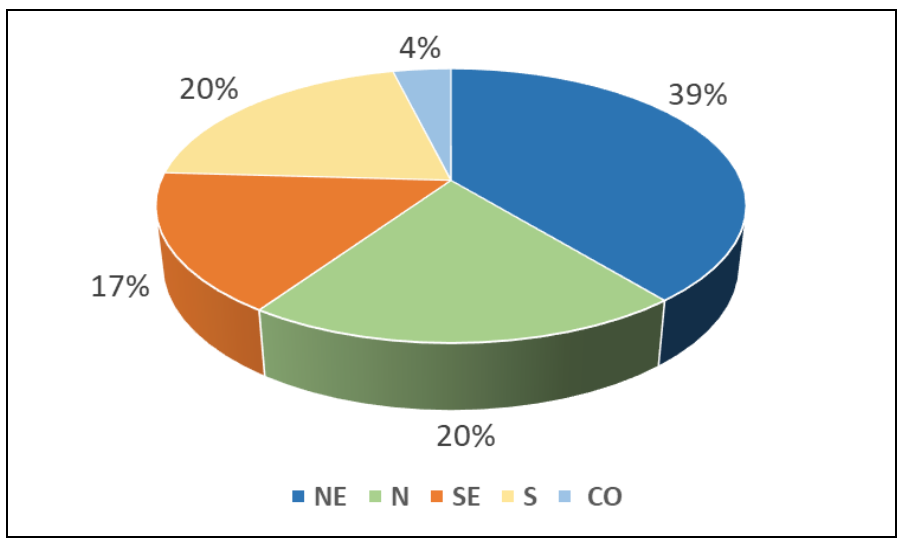

Fonte: Gráfico elaborado pela autora 
No mesmo documento (BRASIL. MEC, 2015[?]), a interiorização proporcionou uma expansão de vagas públicas que se diferenciou do tradicional modelo de oferta de vagas nas capitais e elevou o número de municípios, atendidos por universidades federais, de 114 para 289, o que representou um crescimento de $153 \%$.

De acordo com o Documento "Análise sobre a Expansão das Universidades Federais 2003 a 2012" (BRASIL. MEC, 2012), nessa primeira fase da expansão ocorreu um crescimento de 30.691 vagas ofertadas para alunos ingressantes nos cursos de graduação nas universidades federais (de 109.184 vagas em 2003 para 139.875 em 2007). O Gráfico 2 mostra que a evolução do ano de 2003 para 2004 foi de 618 vagas; de 2004 para 2005 foi de 6.546; de 2005 para 2006 foi de 15.855; e de 2006 para 2007 foi de 7.672 .

Gráfico 2. Crescimento do número de vagas ofertadas nos cursos na graduação, nas IFES

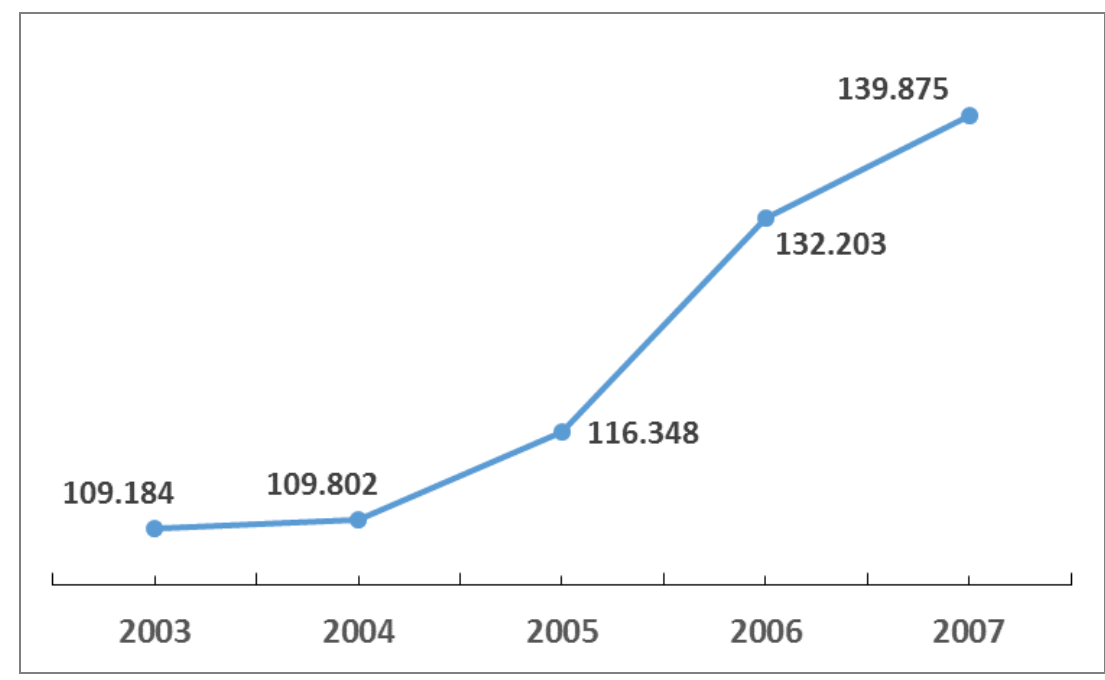

Fonte: Gráfico elaborado pela autora

O documento "A democratização e expansão da educação superior no país 2003 - 2014. Balanço das principais políticas e programas" (BRASIL. MEC, 2015[?]) mostra que o crescimento do número de cursos nas universidades federais foi de 582 (de 2.078 cursos em 2003 para 2.660 em 2007). O Gráfico 3 mostra que a evolução do número de cursos de 2003 para 2004 foi de 24; de 2004 para 2005 foi de 54; de 2005 para 2006 foi de 308; e de 2006 para 2007 foi de 196. 
Gráfico 3. Crescimento do número de cursos na graduação, nas IFES

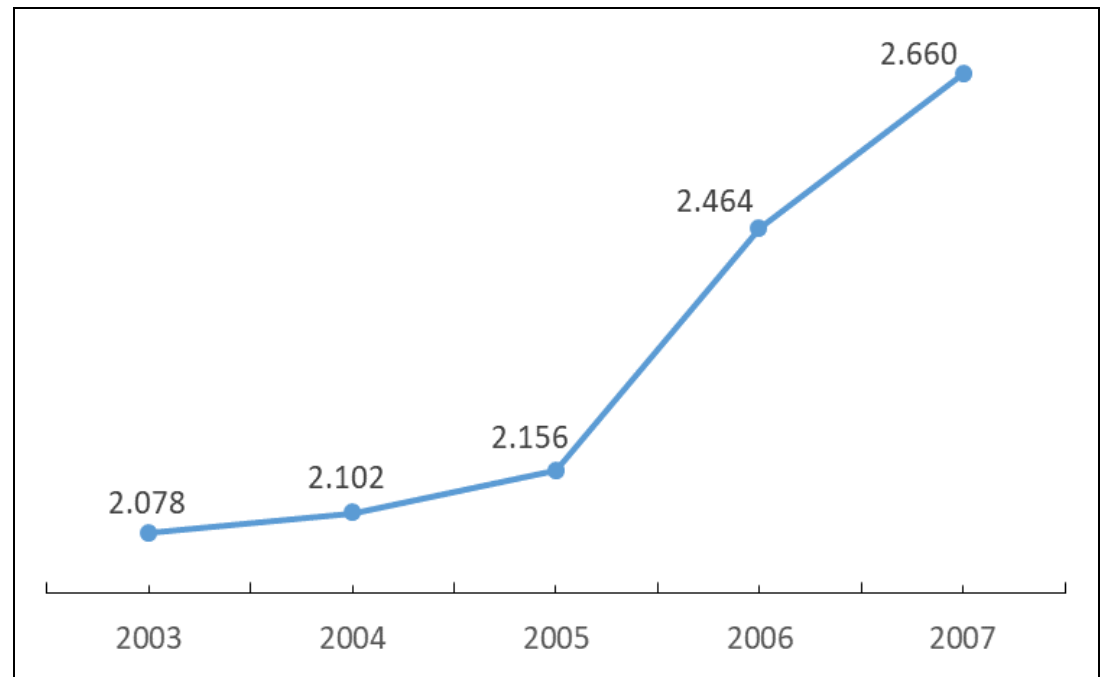

Fonte: Gráfico elaborado pela autora.

Ocorreu um crescimento de 50.817 no número de matrículas na graduação (de 527.719 matrículas em 2003 para 578.536 em 2007). ("Análise sobre a Expansão das Universidades Federais 2003 a 2012" (BRASIL. MEC, 2012)

O Gráfico 4 mostra que a evolução de matrículas na graduação foi de 6.173 de 2003 para 2004; 15.279 de 2004 para 2005; 7.060 de 2005 para 2006; e de 22.305 de 2006 para 2007.

Gráfico 4. Crescimento de número de matrículas na graduação, nas IFES

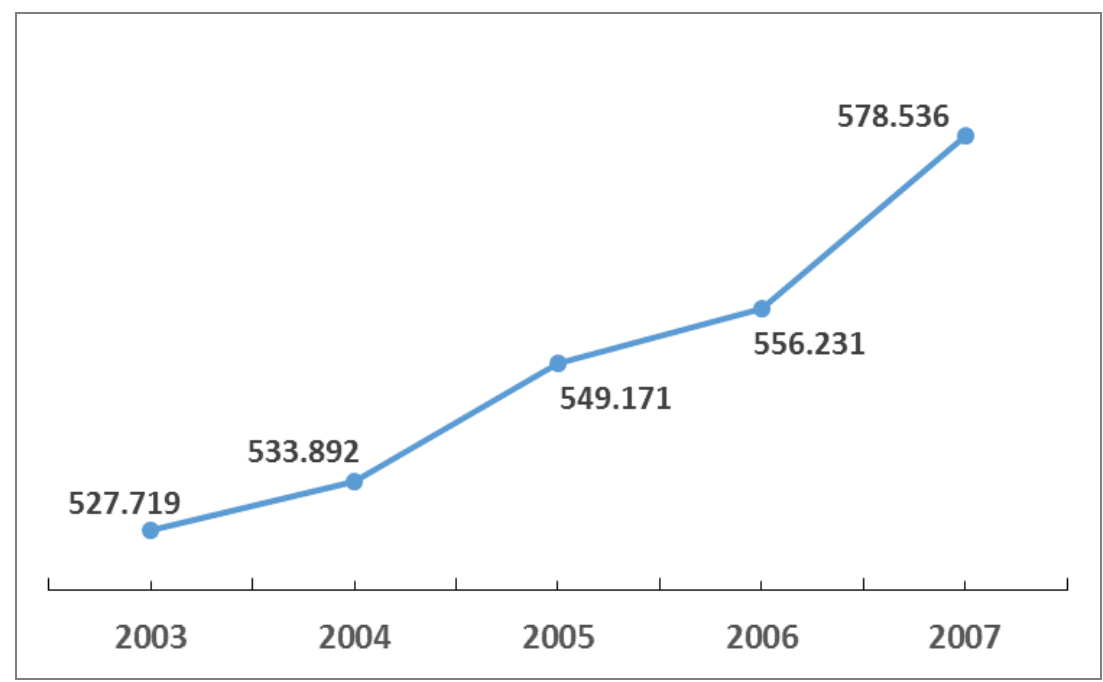

Fonte: Gráfico elaborado pela autora. 


\subsection{O REUNI na expansão das IFES (2008-2012)}

Nesse subcapítulo, procurou-se responder, a partir dos documentos oficiais, as seguintes questões: "Qual o panorama da educação superior no Brasil, no momento em que foi instituído o REUNI?"; "Quais as diretrizes, objetivos, dimensões e metas definidas para adesão ao REUNI?"; e "Quais foram os resultados desta fase de expansão?"

\subsubsection{Panorama da educação superior no Brasil no momento em que foi instituído o REUNI}

Para o entendimento desse panorama, os seguintes documentos foram analisados:

a) BRASIL. Ministério da Educação. O Plano de Desenvolvimento da Educação. Razões, Princípios e Programas. Brasília, 24 de abril de 2007a.

b) BRASIL, 2007. Decreto $n^{\circ}$ 6.096, de 24 de abril de 2007b. Institui 0 Programa de Apoio a Planos de Reestruturação e Expansão das Universidades Federais - REUNI. Presidência da República. Brasília, DF: Diário Oficial da União de 25.04.2007.

c) BRASIL. Portaria n 552 SESu/MEC, de 25 de junho de 2007c: Diretrizes Gerais do Programa de Apoio a Planos de Reestruturação e Expansão das Universidades Federais - REUNI. GRUPO ASSESSOR. Brasília, DF: MEC; Secretaria da Educação Superior, 2007.

d) BRASIL. Ministério da Educação. Programa de Apoio a Planos de Reestruturação e Expansão das Universidades Federais. Reuni 2008 Relatório de Primeiro Ano. Brasília (DF), 30 de outubro de 2009.

e) BRASIL. Ministério da Educação. Análise sobre a Expansão das Universidades Federais 2003 a 2012. Brasília, 2012

f) BRASIL. Ministério da Educação. A democratização e expansão da educação superior no país 2003 - 2014. Balanço das principais políticas e programas. 2015[?]. 
$\mathrm{Na}$ análise temática desses documentos, identificou-se 49 UC, com 113 UR, das quais emergiram as seguintes categorias e suas respectivas subcategorias:

Reforço ao panorama já delineado no período inicial de expansão das IFES.

Reconhecimento de sinais de esgotamento oriundos da expansão das universidades privadas.

Articulação dos eixos da expansão e definição mais precisa das metas.

$\checkmark$ Expansão da oferta de vagas do ensino superior com qualidade, de modo decisivo e sustentado,

$\checkmark$ Reconhecimento da necessidade de colaboração e de compartilhamento de competências,

$\checkmark$ Reconhecimento da necessidade de responsabilização (accountability), da mobilização social e do regime de colaboração,

$\checkmark$ Adoção de novas diretrizes e parâmetros para efetivação e aperfeiçoamento dos resultados obtidos.

Instituição do PDE, como avanço do PNE, em relação à necessidade de reestruturação de grande alcance do parque universitário federal.

$\checkmark$ Ruptura de uma execução marcada pela neutralidade.

Assunção de uma visão sistêmica da educação e da sua relação com a ordenação territorial e o desenvolvimento econômico e social. Reconhecimento da educação como um processo de socialização e individuação voltado para a autonomia,

$\checkmark$ Reconhecimento e desenvolvimento das potencialidades locais,

$\checkmark$ Reconhecimento da potencialidade dos planos setoriais.

Reconhecimento da necessidade de inovações curriculares na graduação.

$\checkmark$ Reconhecimento da precocidade na escolha de carreira profissional,

$\checkmark$ Reconhecimento da ociosidade no período noturno, 
$\checkmark$ Reconhecimento das altas taxas de evasão nos cursos de graduação,

$\checkmark$ Necessidade de articulação da graduação com a pós-graduação.

\section{Reconhecimento da necessidade de expansão dos cursos noturnos.}

\section{Reconhecimento da necessidade de uma política nacional de assistência estudantil.}

$\checkmark$ Necessidade de sustentação à adoção de uma política de ações afirmativas com a efetiva garantia de permanência de estudantes.

Reconhecimento da necessidade de uma política nacional de formação de professores.

Uma primeira categoria, que emerge da análise documental dos documentos, é o Reforço ao panorama já delineado no período inicial de expansão das IFES. Nessa categoria, as principais subcategorias, já apontadas no subcapítulo 4.1, foram reenfatizadas, no que se refere à consideração da educação superior como objeto de permanente atenção, por parte da sociedade, do Governo e das comunidades acadêmicas; bem como à necessidade de elaboração de políticas mais eficazes e duradouras, com o reconhecimento da educação superior pública como referência e orientação para o sistema educacional brasileiro.

Nesse sentido, reconhece-se a importância do Estado no financiamento da educação superior pública e a necessidade de democratização no seu processo de expansão. Nessa fase, foi enfatizado o reconhecimento da necessidade de maior autonomia para a educação superior pública e do papel estratégico da avaliação e do Sistema Nacional de Educação Superior. Reconhecia-se também o papel estratégico da educação superior pública como uma possibilidade de maior inclusão social e de produção e disseminação do conhecimento, bem como um veículo de geração e de transferência de inovação tecnológica que articula o ensino, a pesquisa e a extensão. Assim, reafirma-se o reconhecimento do papel relevante da educação superior pública no desenvolvimento social e econômico do País.

Outra categoria, que surgiu da análise documental, foi o Reconhecimento de sinais de esgotamento oriundos da expansão das universidades privadas. Os documentos salientaram a situação de crise da educação superior, em especial, das 
universidades federais. Esse cenário repercutiu, de maneira negativa, nas instituições privadas, que viveram uma expansão recorde no período compreendido entre 1994 e 2004, mas que, àquele momento, encontravam-se ameaçadas pelo risco da inadimplência generalizada do alunado, dos segmentos sociais incapazes de arcar com o alto custo da educação superior e pela saturação de mercado profissional.

\section{Articulação dos eixos da expansão e definição mais precisa das metas} foi outra categoria presente nos documentos que apontou para a necessidade de promoção, de consolidação e de ampliação dos processos de transformação da universidade pública, por meio da expansão da oferta de vagas, de modo sustentável, do ensino superior e de uma reestruturação acadêmica com qualidade. Nesse contexto, os documentos salientaram a Expansão da oferta de vagas do ensino superior com qualidade, de modo decisivo e sustentado, em que a proposta de recuperação orçamentária estivesse em sintonia com a avaliação e a regulação das IFES.

O Reconhecimento da necessidade de colaboração e de compartilhamento de competências políticas, técnicas e financeiras, para a execução de programas de manutenção e desenvolvimento da educação, era enfatizado e se reconhecia a atuação das universidades federais, sem ferir a autonomia de cada uma delas.

O Reconhecimento da necessidade de responsabilização (accountability) da mobilização social e do regime de colaboração, sobretudo da classe política, e a mobilização da sociedade, como dimensões indispensáveis de um plano de desenvolvimento da educação, era mencionado igualmente.

Após uma primeira fase da expansão, focou-se na reestruturação dessas instituições com a Adoção de novas diretrizes e parâmetros para efetivação e aperfeiçoamento dos resultados obtidos. Os documentos apontaram para a necessidade de um processo de reestruturação dos recursos humanos, da infraestrutura e das carreiras das universidades federais.

A Instituição do PDE, como avanço do PNE em relação à necessidade de reestruturação de grande alcance do parque universitário federal, foi outro fato marcante nessa etapa. O PDE visava dar consequência às metas quantitativas com a Ruptura de uma execução marcada pela neutralidade. O PDE foi concebido como 
um passo em direção à construção de uma resposta institucional, amparada na concepção sistêmica de educação.

Nesse contexto, os documentos salientaram a predominância de uma visão fragmentada da educação no país, diferentemente da visão sistêmica proposta pelo PDE, o que fez emergir, como princípio, a categoria Assunção de uma visão sistêmica da educação e da sua relação com a ordenação territorial e o desenvolvimento econômico e social, em que o enlace entre a educação, o território e o desenvolvimento era um de seus resultados. O documento "O Plano de Desenvolvimento da Educação. Razões, Princípios e Programas" (BRASIL, MEC, 2007a) mencionava que:

\begin{abstract}
"Diferentemente da visão sistêmica que pauta o PDE, predominou no Brasil, até muito recentemente, uma visão fragmentada da educação, como se níveis, etapas e modalidades não fossem momentos de um processo, cada qual com objetivo particular, integrados numa unidade geral; como se não fossem elos de uma cadeia que deveriam se reforçar mutuamente. Tal visão fragmentada partiu de princípios gerencialistas e fiscalistas, que tomaram os investimentos em educação como gastos, em um suposto contexto de restrição fiscal." (BRASIL, MEC, 2007a)
\end{abstract}

O Reconhecimento da educação como um processo de socialização e individuação voltado para a autonomia era salientado e não poderia ser, artificialmente, segmentado de acordo com a conveniência administrativa ou fiscal. Os documentos mostravam que era necessária a promoção da articulação entre as políticas de orientação educacional, por meio da ruptura de uma visão fragmentada da educação e evidenciavam o Reconhecimento e desenvolvimento das potencialidades locais, mediante à articulação com o desenvolvimento socioeconômico realizado no território, ordenado de acordo com a lógica do arranjo educativo - local, regional ou nacional. O mesmo documento (BRASIL, MEC, 2007a) mencionava que:

“Tal concepção implica, adicionalmente, não apenas compreender o ciclo educacional de modo integral, mas, sobretudo, promover a articulação entre as políticas especificamente orientadas a cada nível, etapa ou modalidade e também a coordenação entre os instrumentos de política pública disponíveis." (BRASIL, MEC, 2007a) 


\begin{abstract}
"Esse alinhamento exige a construção da unidade dos sistemas educacionais como sistema nacional - o que pressupõe multiplicidade e não uniformidade (...)exige pensar etapas, modalidades e níveis educacionais não apenas na sua unidade, mas também a partir dos necessários enlaces da educação com a ordenação do território e com o desenvolvimento econômico e social, única forma de garantir a todos e a cada um o direito de aprender até onde o permitam suas aptidões e vontade." (BRASIL, MEC, 2007a)
\end{abstract}

Os documentos também evidenciaram o Reconhecimento da potencialidade dos planos setoriais, salientado como uma necessidade de sintonia das políticas públicas e uma condição de exigência do desenvolvimento econômico e social.

Outra categoria, que emergiu dos documentos analisados, foi 0 Reconhecimento da necessidade de inovações curriculares na graduação. Os documentos reforçavam que o sistema de educação superior brasileiro conservava, até então, modelos de formação acadêmica e profissional superados, tanto acadêmicos como institucionais, com a prevalência de uma concepção fragmentada da educação e do conhecimento que precisavam passar por profundas transformações. O documento "Diretrizes Gerais do Programa de Apoio a Planos de Reestruturação e Expansão das Universidades Federais - REUNI" (BRASIL, MEC, 2007c) mencionava que:

"No plano operacional, algumas constatações acerca de aspectos
problemáticos da estrutura e funcionamento repetem, aprofundam e
amplificam o conjunto de problemas estruturais herdados do velho regime
de formação. Os atuais cursos de graduação são orientados quase que
exclusivamente para a formação profissional e, mesmo aqueles que não
têm essa natureza, como os bacharelados em áreas básicas, mantêm
currículos concentrados, sem abertura para outras áreas do conhecimento."
(BRASIL. MEC. 2007c)

A Necessidade de articulação da graduação com a pós-graduação era realçada. A organização acadêmica incorporava currículos de graduação pouco flexíveis e permitia um distanciamento entre a graduação e a pós-graduação. Os documentos demonstravam aspectos problemáticos na estrutura e funcionamento acadêmicos, herdados do antigo regime de formação e mencionavam o Reconhecimento da precocidade na escolha de carreira profissional e da ociosidade no período noturno nos espaços físicos das unidades universitárias, o que demonstrava o Reconhecimento das altas taxas de evasão nos cursos de graduação. 
A proposta de expansão, na oferta de vagas, focou, igualmente, nos cursos noturnos. O PNE (2001-2010) ressaltava a importância da expansão de vagas no período e considerava que as universidades, sobretudo as federais, possuíam espaço físico para esse fim. Nesse panorama, surgiu a categoria Reconhecimento da necessidade de expansão dos cursos noturnos para assegurar ao aluno trabalhador o ensino de qualidade a que tinha direito, nas mesmas condições de que dispunham os estudantes do período diurno, com um melhor aproveitamento das estruturas físicas e do corpo docente das IFES.

O Reconhecimento da necessidade de uma política nacional de assistência estudantil que apontasse para a Necessidade de sustentação à adoção de uma política de ações afirmativas com efetiva garantia de permanência de estudantes foi também mencionado.

Como última categoria, que emergiu dessa análise documental, o Reconhecimento da necessidade de uma política nacional de formação de professores era mencionado e evidenciava a importância da educação superior como formadora de recursos humanos altamente qualificados.

\subsubsection{As diretrizes, objetivos, dimensões e metas definidas para adesão ao REUNI}

Nessa etapa, os seguintes os documentos foram analisados:

a) BRASIL. Decreto $n^{\circ}$ 6.096, de 24 de abril de 2007b. Institui o Programa de Apoio a Planos de Reestruturação e Expansão das Universidades Federais - REUNI. Presidência da República. Brasília, DF: Diário Oficial da União de 25.04.2007.

b) BRASIL. Portaria No 552 SESu/MEC, de 25 de junho de 2007c: Diretrizes Gerais do Programa de Apoio a Planos de Reestruturação e Expansão das Universidades Federais - REUNI. GRUPO ASSESSOR. Brasília, DF: MEC; Secretaria da Educação Superior, 2007. 
c) ASSOCIAÇÃO NACIONAL DOS DIRIGENTES DAS INSTITUIÇÕES FEDERAIS DE ENSINO SUPERIOR. Consolidação dos dados acadêmicos, orçamentários e de pessoal referentes aos acordos de metas do Programa de Apoio a Planos de Reestruturação das Universidades - REUNI. [Relatório de Consultoria de Maria leda Costa Diniz]. Brasília (DF). Outubro de 2009.

O REUNI foi aprovado com o objetivo de atender os princípios preconizados para a educação superior pelo PDE, em que se explicitava a expansão da oferta de vagas para que jovens entre 18 e 24 anos tivessem acesso a esse nível educacional. No artigo $2^{\circ}$ do decreto, que o instituiu, estão elencadas as seguintes diretrizes (BRASIL, 2007c):

I. Redução das taxas de evasão, ocupação das vagas ociosas e aumento de vagas de ingresso, especialmente no período noturno;

II. Ampliação da mobilidade estudantil, com a implantação de regimes curriculares e sistemas de títulos que possibilitem a construção de itinerários formativos, mediante o aproveitamento de créditos e a circulação de estudantes entre instituições, cursos e programas de educação superior; III. Revisão da estrutura acadêmica, com reorganização dos cursos de graduação e atualização de metodologias de ensino-aprendizagem, buscando a constante elevação da qualidade;

IV. Diversificação das modalidades de graduação, preferencialmente não voltadas à profissionalização precoce e especializada;

V. Ampliação de políticas de inclusão e assistência estudantil; e

VI. Articulação da graduação e pós-graduação e da educação superior com a educação básica.

O Formulário de Apresentação de Propostas possuía seis dimensões. Cada dimensão continha diferentes aspectos específicos e pontuava ações que seriam implementadas. As dimensões definidas foram:

Ampliação da oferta de educação superior pública:

- a ação devia ser centrada no aumento de vagas de ingresso, em especial no turno noturno;

- redução das taxas de evasão;

- ocupação das vagas ociosas.

Reestruturação acadêmico-curricular:

- revisão da estrutura acadêmica, buscando a constante elevação da qualidade;

- reorganização dos cursos de graduação;

- diversificação das modalidades de graduação, preferencialmente com superação da profissionalização precoce e especializada;

- implantação de regimes curriculares e sistemas de títulos que possibilitem a construção de itinerários formativos;

- previsão de modelos de transição.

Renovação pedagógica da educação superior:

- articulação da educação superior com a educação básica, profissional e tecnológica;

- atualização de metodologias (e tecnologias) de ensino-aprendizagem; 
- previsão de programas de capacitação pedagógica, especialmente quando for o caso de implementação de um novo modelo.

D. Mobilidade intra e interinstitucional, tem a intenção de promover a mobilidade estudantil mediante o aproveitamento de créditos e a circulação de estudantes entre cursos e programas, e entre instituições de educação superior.

E. Compromisso social da instituição, o qual se alvitra políticas de inclusão; programas de assistência estudantil; e políticas de extensão universitária.

F. Suporte da pós-graduação ao desenvolvimento e aperfeiçoamento qualitativo dos cursos de graduação, por meio da articulação da graduação com a pós-graduação: expansão qualiquantitativa da pós-graduação orientada para a renovação pedagógica da educação superior. (BRASIL, 2007c).

Em cada subitem, a universidade deveria fazer um diagnóstico da situação em que se encontrava naquele determinado momento; traçar as metas a serem alcançadas com o cronograma de execução; e definir as estratégias para o alcance das mesmas, assim como as etapas e indicadores a serem utilizados. (BRASIL, 2007c).

Para a adesão ao programa, requeria-se a formulação de um projeto de reestruturação e expansão que seria submetido à aprovação dos órgãos superiores de cada instituição. As propostas deveriam atender às metas e às diretrizes delineadas no artigo $2^{\circ}$ do Decreto $n^{\circ}$ 6.096/2007 (BRASIL, 2007b), com ênfase na redução das taxas de evasão, na ocupação das vagas ociosas e no aumento de vagas de ingresso, especialmente, no período noturno.

\subsubsection{Resultados do REUNI na expansão da graduação nas IFES (2008-2012)}

$\mathrm{Na}$ perspectiva de responder, quais foram os resultados do REUNI na expansão da graduação nas IFES, foram considerados os seguintes documentos:

a) BRASIL. Ministério da Educação. Programa de Apoio a Planos de Reestruturação e Expansão das Universidades Federais. Reuni 2008 Relatório de Primeiro Ano. Brasília (DF), 30 de outubro de 2009.

b) ASSOCIAÇÃO NACIONAL DOS DIRIGENTES DAS INSTITUIÇÕES FEDERAIS DE ENSINO SUPERIOR. Relatório de Acompanhamento do Programa de Apoio a Planos de Reestruturação e Expansão das Universidades Federais - REUNI. Brasília (DF): ANDIFES, jan. 2010. 
c) BRASIL. Ministério da Educação. Relatório da Comissão Constituída pela Portaria no 126/2012, sobre a Análise sobre a Expansão das Universidades Federais 2003 a 2012. Brasília. 2012.

d) BRASIL. Ministério da Educação. Análise sobre a Expansão das Universidades Federais 2003 a 2012. Brasília, 2012.

e) BRASIL. Ministério da Educação. A democratização e expansão da educação superior no país 2003 - 2014. Balanço das principais políticas e programas. 2015[?].

\subsubsection{Primeiro ano do Programa REUNI}

Em 2007, existiam 55 universidades federais em funcionamento e, ao final daquele ano, 53 aderiram ao programa, em duas chamadas.

A primeira chamada, para implantação do programa no $1^{\circ}$ semestre 2008 , foi realizada em 29 de outubro de 2007, com a participação de 42 universidades, conforme demonstrado no Quadro 2.

Quadro 2. Universidade federais que aderiram ao REUNI na primeira chamada

\begin{tabular}{|l|l|l|}
\hline Região & IFES & Nome da IFES \\
\hline Nordeste & UFPI & Fundação Universidade Federal do Piauí \\
\cline { 2 - 3 } & UFS & Fundação Universidade Federal de Sergipe \\
\cline { 2 - 3 } & UFMA & Fundação Universidade Federal do Maranhão \\
\cline { 2 - 3 } & UFBA & Universidade Federal da Bahia \\
\cline { 2 - 3 } & UFCG & Universidade Federal de Campina Grande \\
\cline { 2 - 3 } & UFC & Universidade Federal do Ceará \\
\cline { 2 - 3 } & UFPB & Universidade Federal da Paraíba \\
\cline { 2 - 3 } & UFPE & Universidade Federal de Pernambuco \\
\cline { 2 - 3 } & UFRN & Universidade Federal do Rio Grande do Norte \\
\cline { 2 - 3 } & UFERSA & Universidade Federal Rural do Semiárido \\
\hline Norte & UFAC & Fundação Universidade Federal do Acre \\
\cline { 2 - 3 } & UNIFAP & Fundação Universidade Federal do Amapá \\
\cline { 2 - 4 } & UFAM & Fundação Universidade Federal do Amazonas \\
\hline
\end{tabular}




\begin{tabular}{|c|c|c|}
\hline Região & IFES & Nome da IFES \\
\hline \multirow[t]{5}{*}{ Norte } & UNIR & Fundação Universidade Federal de Rondônia \\
\hline & UFRR & Fundação Universidade Federal de Roraima \\
\hline & UFT & Fundação Universidade Federal do Tocantins \\
\hline & UFPA & Universidade Federal do Pará \\
\hline & UFRA & Universidade Federal Rural da Amazônia \\
\hline \multirow[t]{13}{*}{ Sudeste } & UFSCar & Fundação Universidade Federal de São Carlos \\
\hline & UFSJ & Fundação Universidade Federal de São João Del Rei \\
\hline & UFV & Fundação Universidade Federal de Viçosa \\
\hline & UFES & Universidade Federal do Espírito Santo \\
\hline & UNIRIO & Universidade Federal do Estado do Rio de Janeiro \\
\hline & UFF & Universidade Federal Fluminense \\
\hline & UFJF & Universidade Federal de Juiz de Fora \\
\hline & UFLA & Universidade Federal de Lavras \\
\hline & UFMG & Universidade Federal de Minas Gerais \\
\hline & UFRJ & Universidade Federal do Rio de Janeiro \\
\hline & UFRRJ & Universidade Federal Rural do Rio de Janeiro \\
\hline & UNIFESP & Universidade Federal de São Paulo \\
\hline & UFTM & Universidade Federal do Triângulo Mineiro \\
\hline \multirow[t]{6}{*}{ Sul } & UFPel & Fundação Universidade Federal de Pelotas \\
\hline & FURG & Fundação Universidade do Rio Grande \\
\hline & UFCSPA & Universidade Federal de Ciências da Saúde de Porto Alegre \\
\hline & UFPR & Universidade Federal do Paraná \\
\hline & UFRGS & Universidade Federal do Rio Grande do Sul \\
\hline & UFSC & Universidade Federal de Santa Catarina \\
\hline \multirow[t]{5}{*}{ Centro-Oeste } & UnB & Fundação Universidade de Brasília \\
\hline & UFGD & Fundação Universidade Federal da Grande Dourados \\
\hline & UFMT & Fundação Universidade Federal de Mato Grosso \\
\hline & UFMS & Fundação Universidade Federal de Mato Grosso do Sul \\
\hline & UFG & Universidade Federal de Goiás \\
\hline
\end{tabular}

Fonte: Quadro elaborado pela autora 
A segunda chamada, para implantação do programa no $2^{\circ}$ semestre de 2008 , foi realizada em 17 de dezembro de 2007, com a participação de 11 universidades, conforme demonstrado no Quadro 3:

Quadro 3. Universidade federais que aderiram ao REUNI na segunda chamada

\begin{tabular}{|l|l|l|}
\hline Região & IFES & Nome da IFES \\
\hline \multirow{4}{*}{ Nordeste } & UNIVASF & Fundação Universidade Federal do Vale do São Francisco \\
\cline { 2 - 3 } & UFAL & Universidade Federal de Alagoas \\
\cline { 2 - 3 } & UFRPE & Universidade Federal Rural de Pernambuco \\
\hline \multirow{4}{*}{ Sudeste } & UFOP & Fundação Universidade Federal de Ouro Preto \\
\cline { 2 - 4 } & UNIFAL-MG & Universidade Federal de Alfenas \\
\cline { 2 - 3 } & UNIFEI & Universidade Federal de Itajubá \\
\cline { 2 - 4 } & UFRB & Universidade Federal do Recôncavo da Bahia \\
\cline { 2 - 3 } & UFU & Universidade Federal de Uberlândia \\
\cline { 2 - 3 } & UFVJM & Universidade Federal dos Vales do Jequitinhonha e Mucuri \\
\hline \multirow{3}{*}{ Sul } & UTFPR & Universidade Tecnológica Federal do Paraná \\
\cline { 2 - 3 } & UFSM & Universidade Federal de Santa Maria \\
\hline
\end{tabular}

Fonte: Quadro elaborado pela autora

A Universidade Federal do ABC (UFABC), criada em 2005, e a Universidade Federal do Pampa (UNIPAMPA), em 2008, não participaram do REUNI e já contavam com as inovações pedagógicas previstas pelo Programa.

O relatório do primeiro ano do Programa REUNI, "Programa de Apoio a Planos de Reestruturação e Expansão das Universidades Federais. Reuni 2008 Relatório de Primeiro Ano. Brasília, 2009" (BRASIL, MEC, 2009), mostrou que, de maneira geral, houve o cumprimento das metas propostas, com alguns casos de superação da previsão inicial, estabelecida pelas universidades federais. 
Os projetos institucionais de adesão ao programa REUNI pactuaram um aumento de vagas para 146.762. Em 2008, as universidades federais ofertaram um total de 147.277 vagas, conforme demonstrado no Quadro 4:

Quadro 4. Número de vagas nos cursos de graduação em 2008, nas IFES

\begin{tabular}{|l|l|l|l|l|l|l|}
\hline \multirow{2}{*}{ IFES } & \multicolumn{3}{|c|}{ Projetadas } & \multicolumn{3}{c|}{ Executadas } \\
\cline { 2 - 7 } & Diurno & Noturno & Total & Diurno & Noturno & Total \\
\hline Total & 108.553 & 38.209 & $\mathbf{1 4 6 . 7 6 2}$ & 109.690 & 37.587 & $\mathbf{1 4 7 . 2 7 7}$ \\
\hline
\end{tabular}

Fonte: Coleta PingIFES (dados de execução) e Simulador REUNI/SIMEC (dados de pactuação).

\subsubsection{O REUNI de 2008-2012}

No período compreendido entre os anos de 2008 e 2012, foram criadas 4 universidades federais, dentre as quais 1 (25\%) na região nordeste, 1 (25\%) na região norte e 2 (50\%) na região sul, conforme demonstrado no Quadro 5:

Quadro 5. Universidades federais criadas entre 2008 e 2012 nas IFES, por região

\begin{tabular}{|l|l|l|}
\hline Região & IFES & Nome da IFES \\
\hline Nordeste & UNILAB & $\begin{array}{l}\text { Universidade da Integração Internacional da Lusofonia } \\
\text { Afro-Brasileira }\end{array}$ \\
\hline Norte & UFOPA & Universidade Federal do Oeste do Pará \\
\hline \multirow{2}{*}{ Sul } & UFFS & Universidade Federal da Fronteira Sul \\
\cline { 2 - 3 } & UNILA & Universidade Federal da Integração Latino-Americana \\
\hline
\end{tabular}

Fonte: SIMEC/MEC.

De acordo com o documento "A democratização e expansão da educação superior no país 2003 - 2014. Balanço das principais políticas e programas" (BRASIL. MEC, 2015[?]) e como demonstrado no Gráfico 5, no período compreendido entre 2008 e 2012 foram criados 78 novos campi: 22 (28\%) na região nordeste; 4 (5\%) na região norte; 19 (24\%) na região sudeste; 28 (36\%) na região sul e $5(7 \%)$ na região centro-oeste. 
Gráfico 5. Campi criados e consolidados nas IFES, por região

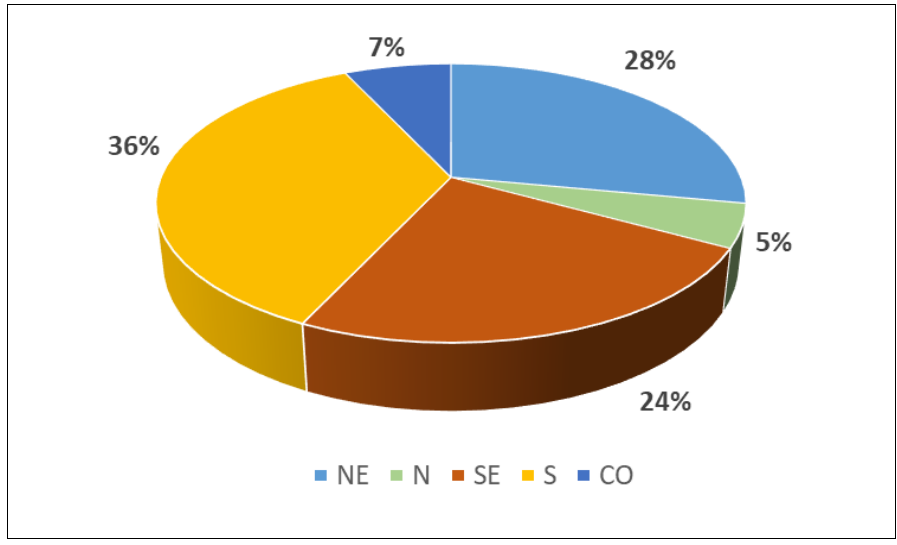

Fonte: Gráfico elaborado pela autora.

De acordo com o documento "Análise sobre a Expansão das Universidades Federais 2003 a 2012" (BRASIL. MEC, 2012b) e com a fase da expansão com a implementação do REUNI ocorreu um crescimento de 80.661 vagas ofertadas para alunos ingressantes nos cursos de graduação das universidades federais (de 150.869 vagas em 2008 para 231.530 em 2011). O Gráfico 6 mostra que a evolução do ano de 2008 para 2009 foi de 36.115 vagas; de 2009 para 2010 foi de 31.168; e de 2010 para 2011 foi de 13.378. O documento não trouxe os dados de 2012, nessa categoria.

Gráfico 6. Crescimento do número de vagas ofertadas nos cursos na graduação, nas IFES

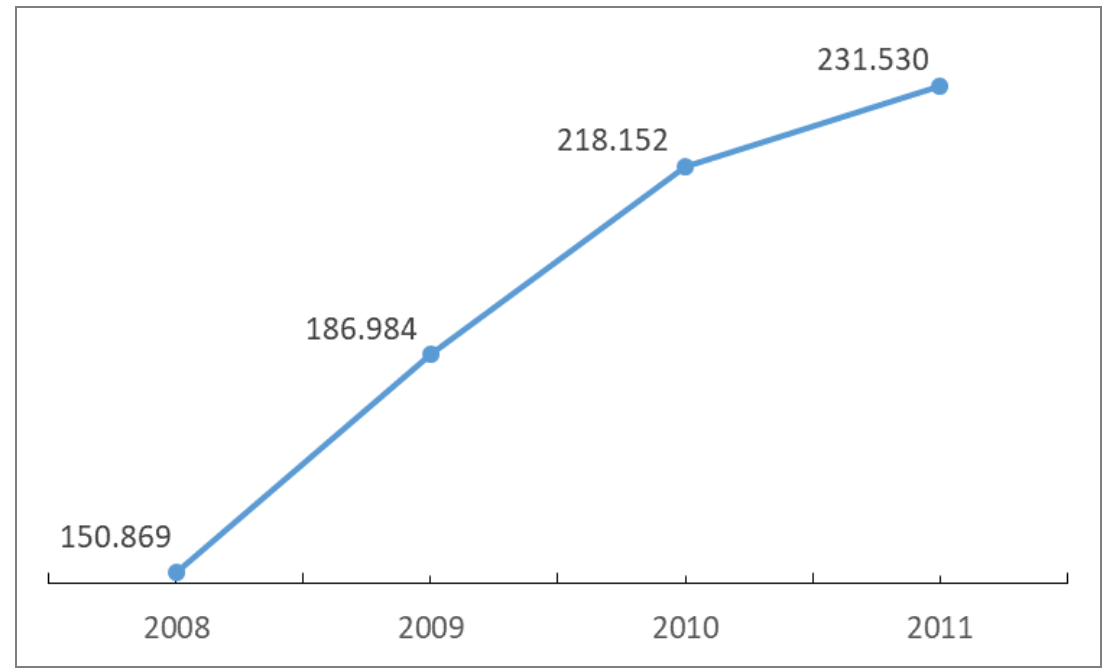

Fonte: Gráfico elaborado pela autora. 
O documento "A democratização e expansão da educação superior no país 2003 - 2014. Balanço das principais políticas e programas" (BRASIL. MEC, 2015[?]) mostrou que o crescimento do número de cursos, nas universidades federais, foi de 1.850 (de 2.822 cursos em 2008 para 4.672 em 2012). O Gráfico 7 mostra que a evolução do número de cursos de 2008 para 2009 foi de 1.046; de 2009 para 2010 foi de 459; de 2010 para 2011 foi de 179; e de 2011 para 2012 foi de 166.

Gráfico 7. Crescimento do número de cursos na graduação, nas IFES

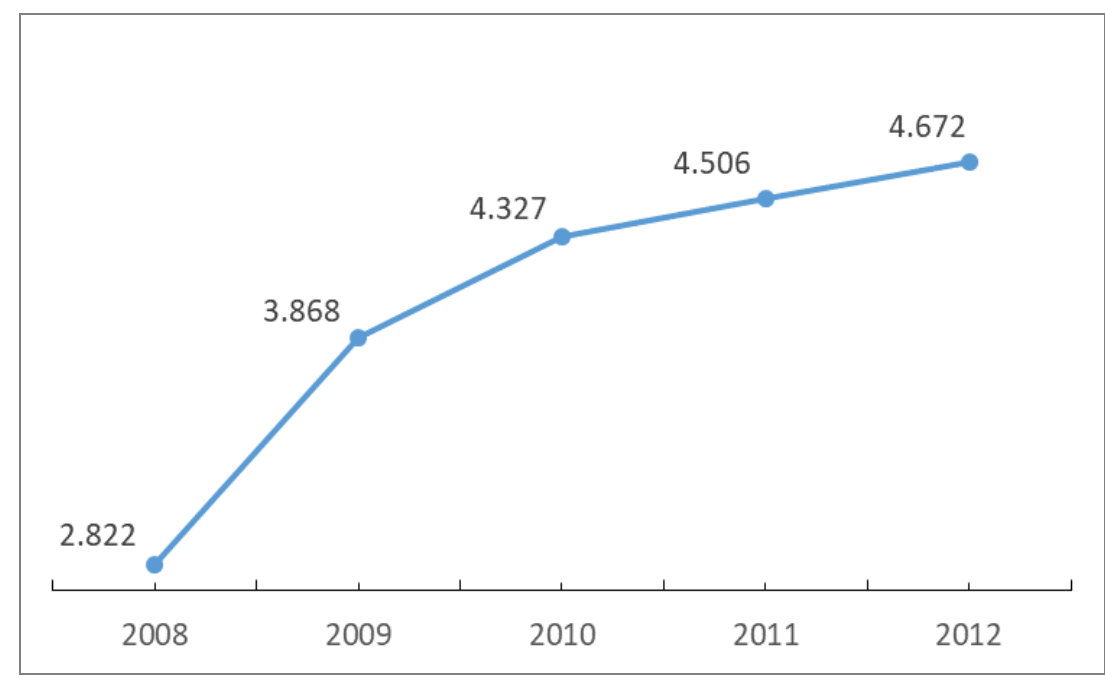

Fonte: Gráfico elaborado pela autora.

No documento "Análise sobre a Expansão das Universidades Federais 2003 a 2012" (BRASIL. MEC, 2012b), os dados mostraram um crescimento de 241.834 no número de matrículas na graduação (de 600.772 matrículas em 2008 para 842.606 em 2011).

O Gráfico 8 mostra que a evolução de matrículas na graduação foi de 95.921 de 2008 para 2009; de 67.198 de 2009 para 2010; e de 78.715 de 2010 para 2011. O documento não trouxe os dados de 2012, nessa categoria. 
Gráfico 8. Crescimento do número de matrículas na graduação, nas IFES

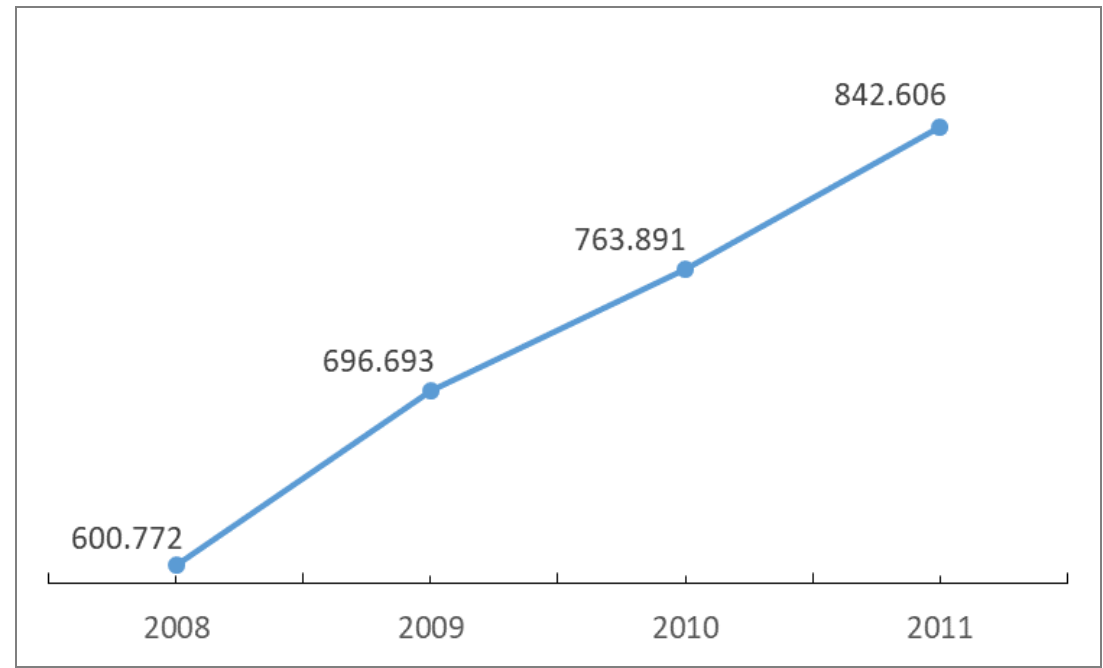

Fonte: Gráfico elaborado pela autora.

$\mathrm{Na}$ finalização desse capítulo, apresenta-se o Quadro 6 que demonstra a evolução das duas fases da expansão nas universidades federais, a partir dos dados quantitativos dos documentos analisados.

Quadro 6. Indicadores globais da primeira fase da expansão da graduação e do REUNI nas universidades federais

\begin{tabular}{|l|r|r|r|r|r|r|}
\hline \multirow{2}{*}{ Indicadores } & \multicolumn{2}{|c|}{ Expansão 1 $\mathbf{1}^{\text {a }}$ fase } & \multicolumn{3}{|c|}{ REUNI } & \multirow{2}{*}{$\%$ Global } \\
\cline { 2 - 7 } & $\mathbf{2 0 0 3}$ & $\mathbf{2 0 0 7}$ & $\mathbf{2 0 0 8}$ & $\mathbf{2 0 1 1}$ & $\mathbf{2 0 1 2}$ & \\
\hline Universidades & 45 & 55 & 55 & - & 59 & $31 \%$ \\
\hline Campi & 148 & 227 & 227 & - & 305 & $106 \%$ \\
\hline Vagas & 109.184 & 139.875 & 150.869 & 231.530 & - & $125 \%$ \\
\hline Cursos & 2.078 & 2.660 & 2.822 & - & 4.672 & $112 \%$ \\
\hline Matrículas & 527.719 & 578.536 & 600.772 & 842.606 & - & $60 \%$ \\
\hline
\end{tabular}

Fonte: Quadro elaborado pela autora.

Observa-se um crescimento global das IFES na primeira fase de expansão (2003-2007), do programa REUNI (2008-2012), no número de criação de universidades federais (31\%), no número de campi (106\%) e no número de cursos (125\%). 
O documento "A democratização e expansão da educação superior no país 2003 - 2014. Balanço das principais políticas e programas. 2015[?]" (BRASIL, 2015[?]) não trouxe os dados de 2012, no que se refere às vagas e às matrículas. $O$ período, analisado para esses dois indicadores, foi de 2008 a 2011 : vagas (112\%) e matrículas (60\%).

\subsection{A expansão na UNIFESP}

Nesse subcapítulo, a partir dos documentos analisados, procurou-se responder, as seguintes questões: "Como estava a UNIFESP na fase inicial da expansão nacional do ensino superior público?"; "Como a UNIFESP aderiu a esse movimento de expansão, no período de 2003 a 2012?"; "O que significou essa expansão em relação aos indicadores quantitativos da graduação?"

\subsubsection{A primeira fase de expansão (2003-2007): A criação de novos campi e cursos}

Com o propósito de facilitar a compreensão e de responder as questões, propostas nesta etapa da investigação, analisaram-se os seguintes documentos:

a) Atas das reuniões do Conselho Universitário da UNIFESP (CONSU), em que se discutiu a expansão no período compreendido entre 2003 e 2012.

b) UNIVERSIDADE FEDERAL DE SÃO PAULO. Relatório de Gestão de 2003, de novembro de 2003.

Em 2003, a UNIFESP ainda se mantinha como uma universidade temática da área da saúde com importante papel no cenário acadêmico nacional e internacional. Possuía um único campus, situado na Vila Clementino e com cinco cursos de graduação: Medicina (1933), Enfermagem (1939), Ciências Biomédicas (1966), Fonoaudiologia (1968) e Tecnologia Oftálmica (1970), todos ligados à Escola Paulista de Medicina, com um total de 1.296 estudantes. (UNIFESP, Relatório de Gestão de 2003, novembro de 2003). 
À época, apresentava um expressivo quadro de estudantes de pós-graduação stricto sensu com um total de 480 matriculados no Mestrado Profissional; de 1.366 no Mestrado Acadêmico; e de 1.206 no Doutorado. Existiam 11 programas de pósgraduação em nível de Mestrado Profissional; 30, em nível de Mestrado Acadêmico; e 37, em nível de Doutorado. (UNIFESP, Relatório de Gestão de 2003, novembro de 2003).

$\mathrm{Na}$ pós-graduação lato sensu, existiam 146 cursos (139 cursos de Especialização e 7 cursos de Aperfeiçoamento) com um total de 1.834 alunos matriculados (1.775 de Especialização e 59 em Aperfeiçoamento). Na Residência Médica, o número de alunos, matriculados nos 41 programas credenciados pela Comissão Nacional de Residência Médica, era de 454. (UNIFESP, Relatório de Gestão de 2003, novembro de 2003).

A partir desse quadro situacional, o processo de expansão da UNIFESP foi significativo em relação à graduação, à pós-graduação (lato e stricto sensu), à pesquisa e à extensão. Como salientado, anteriormente, nas questões de pesquisa e nos objetivos desta dissertação, concentrou-se no crescimento da graduação.

Ao se analisar as atas do CONSU, observou-se que, em reunião realizada em 29 de outubro de 2003, o Magnífico Reitor ${ }^{6}$ comentou, à época, que o então Ministro da Educação ${ }^{7}$, tinha comunicado aos reitores das universidades públicas brasileiras sobre um processo de reestruturação que resultaria em uma grande expansão do ensino superior público no Brasil. Esse fato não constou da pauta da reunião e se constituiu, apenas, de um comunicado sem maiores discussões a respeito.

A etapa inicial do processo de expansão na graduação começou, efetivamente, em 2004. No seu início, evidenciaram-se as primeiras articulações da UNIFESP no âmbito da primeira fase do Programa de Expansão das Universidades Federais. Essas articulações se consistiram em negociações, com o então Secretário da Educação Superior ${ }^{8}$, para implantação de um campus no litoral. Apesar do interesse da Universidade Federal de São Carlos (UFSCar), a UNIFESP teve prioridade para a viabilização do projeto. As primeiras negociações

\footnotetext{
${ }^{6}$ Ulysses Fagundes Neto - Reitor da UNIFESP no período de 2003-2008

${ }^{7}$ Cristovam Ricardo Cavalcanti Buarque - Ministro da Educação no período de 2003 a 2004

${ }^{8}$ Carlos Roberto Antunes dos Santos - Secretário da Educação Superior no período de 2003 a 2004
} 
prosseguiram com o intuito de implantar um campus em Interlagos e contaram com a intermediação da coordenadora de desenvolvimento e expansão ${ }^{9}$ e do pró-reitor de extensão ${ }^{10}$, junto a um vereador ${ }^{11}$, com a finalidade de obter um terreno ao lado do Autódromo de Interlagos. Nessa mesma reunião, foi feito um primeiro comunicado sobre a implantação do Programa de Ações Afirmativas na Universidade. (UNIFESP, Ata do CONSU de 11 de fevereiro de 2004).

A discussão sobre a implantação desse programa na universidade foi, novamente, abordada em março de 2004, em consideração à Portaria no 1.369, de 18 de dezembro de 2003, na qual o governo federal solicitava a inclusão dessa discussão na pauta dos conselhos universitários de todas as universidades brasileiras. A coordenadora da Comissão de Estudos Institucionais para Ações Afirmativas da UNIFESP ${ }^{12}$ propôs um aumento em $10 \%$ nas vagas de graduação existentes. As vagas seriam destinadas aos negros/pardos e indígenas, provenientes de escolas públicas. (UNIFESP, Ata do CONSU de 10 de março de 2004).

Essa proposta foi discutida no Conselho de Graduação (CONGRAD) e, posteriormente, redigiu-se uma resolução para aprovação e homologação no CONSU, com a inclusão de índios nas quotas (UNIFESP, Resolução nํ2 23/2004, de 14 de abril de 2004). Com uma ressalva feita pelo reitor, em que condiciona o cumprimento dessa resolução à garantia de financiamento pelo MEC, a proposta foi aprovada com 31 votos a favor, 15 votos contra e 7 abstenções. (UNIFESP, Ata do CONSU de 14 de abril de 2004).

Ainda em março de 2004, a proposta de criação de dois novos campi (Baixada Santista e Santo Amaro) foi colocada em votação e aprovada, com apenas um voto contrário. (UNIFESP, Ata do CONSU de 3 março de 2004).

\footnotetext{
${ }^{9}$ Lucila Amaral Carneiro Vianna - Coordenadora de Desenvolvimento e Expansão no período de 2003 a 2008

${ }^{10}$ Walter Manna Albertoni - Pró-Reitor de Extensão no período de 2003 a 2008

${ }^{11}$ Carlos Giannazi - vereador da cidade de São Paulo no período de 2001 a 2007

${ }^{12}$ Helena Bonciani Nader - Coordenadora da Comissão de Estudos Institucionais para Ações Afirmativas da UNIFESP no período de 2003 a 2008
} 
As tratativas, para implantação do campus na Baixada Santista, prosseguiram em um encontro com a bancada paulista de deputados em Brasília, com a participação de uma deputada federal ${ }^{13}$ e do reitor da UNIFESP e culminou em entendimentos e proposta de início da discussão com a Prefeitura Municipal de Santos. O projeto contou, igualmente, com o apoio do secretário da educação superior que se mostrou muito interessado na interiorização da UNIFESP.

$\mathrm{Na}$ continuidade das tratativas, o reitor e os diretores administrativos da UNIFESP, da Associação Paulista para o Desenvolvimento da Medicina (SPDM) e do Hospital São Paulo (HSP) estiveram na cidade de Santos, em abril de 2004, onde assinaram um convênio com a prefeitura municipal de Santos, para criação do referido campus. (UNIFESP, Ata do CONSU de 14 de abril de 2004).

Em reunião realizada no dia 9 de junho, o reitor comunicou aos membros do CONSU: a aprovação, por unanimidade, na câmara municipal de Santos do convênio de cooperação entre a UNIFESP e a prefeitura; a confirmação do Presidente da República ${ }^{14}$, referente à implantação do Campus Baixada Santista, em audiência com então Ministro da Educação ${ }^{15}$; e sua inserção no Plano de Expansão das Universidades Federais. Foi também informado que as vagas para servidores docentes e técnico-administrativos haviam sido aprovadas pelo MEC e encaminhadas ao Ministério do Planejamento (MP) para estudo. (UNIFESP, Ata do CONSU de 9 de junho de 2004).

Na reunião do CONSU, de agosto de 2004, foram apresentados, pelo próreitor de graduação ${ }^{16}$, os novos cursos de graduação que seriam implantados no campus: Educação Física, Fisioterapia, Nutrição, Psicologia e Terapia Ocupacional. Nessa data, foi designado um professor ${ }^{17}$ para exercer 0 cargo de Diretor Acadêmico do novo campus. (UNIFESP, Ata do CONSU de 19 de agosto de 2004).

\footnotetext{
${ }^{13}$ Mariângela Duarte Costa - Deputada Federal no período de 2003 a 2007

${ }^{14}$ Luis Inácio Lula da Silva - Presidente da República de 2003 a 2011

${ }^{15}$ Tarso Fernando Herz Genro - Ministro da Educação no período de 2004 a 2005

${ }^{16}$ Edmund Chada Baracat - Pró-Reitor de Graduação no período de 2003 a 2005

${ }^{17}$ Nildo Alves Batista - Diretor Acadêmico do Campus Baixada Santista no período de 2006 a 2011
} 
Em 14 de setembro de 2004, realizou-se a aula inaugural do Campus Baixada Santista. De acordo com o reitor "a cerimônia emocionou a todos, pois foi um momento especial, representando a expansão da UNIFESP para outro campus". Esse evento contou com a presença do Prefeito do Município de Santos ${ }^{18}$, de uma deputada federal ${ }^{19}$, de vários vereadores e de deputados da Baixada Santista. A UNIFESP foi representada pelo reitor, pelo vice-reitor ${ }^{20}$, pela chefe de gabinete ${ }^{21}$, pelos pró-reitores e por alguns funcionários. (UNIFESP, Ata da reunião do CONSU de 15 de setembro de 2004).

Com a inauguração do campus, instalado em imóvel cedido pela Prefeitura Municipal de Santos e localizado à Av. Ana Costa, 95, dois cursos sequenciais tiveram o início de suas atividades e contaram com os recursos humanos e materiais do Campus São Paulo, foram eles: Educação em Saúde e Gestão em Saúde. Dois meses depois, o reitor comunicou que, conforme informações do então Secretário da Educação Superior ${ }^{22}$ e do diretor do Departamento de Desenvolvimento do Ensino Superior do $\mathrm{MEC}^{23}$, seria realizado um concurso público, no qual seriam oferecidas um total de 2.500 vagas, em 2005, para os servidores docentes e técnicoadministrativos. As vagas determinadas para o Campus Baixada Santista faziam parte das 500 vagas que seriam destinadas à expansão das universidades. $O$ reitor esclareceu que o concurso seria aberto, especificamente, para o campus, sem a possibilidade do servidor ser itinerante, pois o campus era considerado pelo MEC como uma expansão e não uma extensão da UNIFESP. (Ata do CONSU de 10 de novembro de 2004).

Para o início da adequação da infraestrutura, mediante emenda de uma deputada federal, foi disponibilizado o valor de $\mathrm{R} \$ 2$ milhões para a UNIFESP. Uma vez que a Prefeitura do Municipal de Santos estava comprometida em fornecer boa parte da infraestrutura logística, foi negociado, junto ao MEC, a utilização de parte desse valor, ou seja, $R \$ 1$ milhão e 600 mil, na finalização da construção da casa da

\footnotetext{
${ }^{18}$ Paulo Roberto Gomes Mansur - Prefeito do Município de Santos no período de 1997 a 2004

${ }^{19}$ Mariângela Duarte Costa - Deputada Federal no período de 2003 a 2007

${ }^{20}$ Sergio Tufik - Vice-reitor da Universidade Federal de São Paulo no período de 2003 a 2008

${ }^{21}$ Lucila Amaral Carneiro Vianna - Chefe de Gabinete no período de 2003 a 2007

${ }^{22}$ Nelson Maculan Filho - Secretário da Educação Superior no período de 2004 a 2006

${ }^{23}$ Manuel Fernando Palácios da Cunha e Melo - Diretor do Departamento de Desenvolvimento do Ensino

Superior no período de 2004 a 2006
} 
Cirurgia da Mão e o restante, $\mathrm{R} \$ 400$ mil, no campus. (Ata do CONSU de 10 de novembro de 2004).

Com relação à infraestrutura, o reitor comunicara que a reforma completa do imóvel da Av. Ana Costa foi feita pela Prefeitura Municipal de Santos e sua conclusão, realizada até o final de 2005. Outros imóveis, que acabaram por fazer parte da infraestrutura do campus, foram: a Hospedaria dos Imigrantes que possuía 20 mil m$^{2}$ e pertencia ao Governo do Estado de São Paulo, bem como dois terrenos da Prefeitura do Município de Santos que continham áreas de 5.080,30 $\mathrm{m}^{2}$ e $5.112,00 \mathrm{~m}^{2}$ e estavam localizados entre a Rua Dr. Manoel Tourinho e Rua Silva Jardim e entre a Rua Silva Jardim e Rua Campos Melo, na Vila Mathias, destinados à instalação da sede definitiva do campus, cuja doação foi publicada no Diário Oficial da União (DOU) em 5 de abril de 2006. UNIFESP. (UNIFESP, Ata do CONSU de 13 de julho de 2005) e (UNIFESP, Ata da reunião do CONSU de 12 de abril de 2006).

Em 2 de agosto, foi assinada a cessão da antiga sede da Hospedaria dos Imigrantes, situada na Rua Silva Jardim, no município de Santos, para a UNIFESP. Nessa ocasião, o reitor comunicou que, em contato com o Secretário da Educação Superior ${ }^{24}$, estava acordada a liberação das primeiras 35 vagas para concurso público de servidor técnico-administrativo, para o campus. Sobre o concurso de servidor docente, o reitor assim se manifestou:

(...)o maior concurso da história da UNIFESP, teve início no dia 8 de agosto - concursos para docentes da Baixada Santista - e que gostaria de destacar a tremenda cooperação e eficiência da Pró-Reitoria de Administração, da Pró-Reitoria de Graduação, em especial da Professora Helena Nader. (UNIFESP, Ata da reunião ordinária do Conselho Universitário da Universidade Federal de São Paulo, de 10 de agosto de 2005).

No dia 4 de outubro de 2005, em Brasília, foi assinado o convênio de expansão do Campus Baixada Santista, com os recursos de Outros Custeios e Capital (OCC) específicos para o mesmo. (UNIFESP, Ata do CONSU de 5 de outubro de 2005).

\footnotetext{
${ }^{24}$ Manuel Fernando Palácios da Cunha e Melo - Secretário da Educação Superior no período de 2006 a 2008
} 
A aula inaugural das atividades de graduação foi ministrada pelo Magnífico Reitor, no dia 6 março de 2006. O evento ocorreu no Teatro Municipal Brás Cubas, em Santos e contou com um público de mais de 400 pessoas entre alunos, pais, docentes e funcionários. Estiveram presentes, também, o então Prefeito de Santos $^{25}$, o Ministro Interino da Educação ${ }^{26}$, o Diretor do Departamento de Política da Educação Superior ${ }^{27}$ e uma deputada federal ${ }^{28}$. (UNIFESP, Ata da reunião do CONSU de 8 de março de 2006).

Em 2006, o campus iniciou, definitivamente, suas atividades com um total de 190 estudantes, distribuídos da seguinte maneira: 40 estudantes em cada um dos cursos de fisioterapia, de nutrição, de educação física e de psicologia e 30, no curso de terapia ocupacional.

Em outubro de 2006, o Diretor Acadêmico ${ }^{29}$ do campus explanou sobre o projeto pedagógico do campus com os 5 cursos já implantados e destacou a "Educação Interprofissional em Saúde" como um princípio formativo e uma proposta de integração entre os cursos. (UNIFESP, Ata da reunião do CONSU de 11 de outubro de 2006).

Em virtude do crescimento das atividades desenvolvidas no campus, fora alugado, em dezembro de 2006, um segundo imóvel, situado na Ponta da Praia, onde as aulas eram ministradas. Os laboratórios, contudo, estavam situados no prédio da Av. Ana Costa. (UNIFESP, Ata da reunião do CONSU de 13 de dezembro de 2006).

Em relação ao campus de Interlagos, com a intervenção de um vereador ${ }^{30}$ junto ao Ministério da Ciência e Tecnologia (MCT), iniciou-se, em março de 2004, as tratativas para o repasse de um terreno de $60 \mathrm{mil} \mathrm{m}^{2}$ para o MEC. No início de setembro de 2004, o reitor comunicou a impossibilidade desse repasse devido à

\footnotetext{
${ }^{25}$ João Carlos Tavares Papa - Prefeito da cidade de Santos no período de 2005 a 2012

${ }^{26}$ Jairo Jorge da Silva - Ministro Interino da Educação em 2004

${ }^{27}$ Godofredo de Oliveira Neto - Diretor do Departamento de Política da Educação Superior no período de 2004 a 2007

${ }^{28}$ Mariângela Duarte Costa - Deputada Federal no período de 2003 a 2007

${ }^{29}$ Nildo Alves Batista - Diretor Acadêmico do Campus Baixada Santista no período de 2006 a 2011

${ }^{30}$ Carlos Giannazi - vereador da cidade de São Paulo no período de 2001 a 2007
} 
ausência de um suporte legal. (UNIFESP, Atas das reuniões do CONSU de 3 de março e 15 de setembro de 2004).

Em reunião, realizada em agosto de 2005, foi solicitada a cessão de um terreno de 15 mil m², localizado em Santo Amaro e de propriedade da Prefeitura do Município de São Paulo, para instalação de um campus. (UNIFESP, Ata do CONSU de 10 de agosto de 2005). A cessão do terreno ocorreu em cerimônia, no dia 1 de outubro de 2005. (UNIFESP, Ata do CONSU de 5 de outubro de 2005).

Nesse campus, agora Unidade Santo Amaro, a proposta inicial foi a da construção de um imóvel para os cursos os acadêmicos de Economia e Administração com ênfase em Gestão em Saúde, como também um prédio de pesquisas, em virtude da facilidade de locomoção oferecida. O então pró-reitor de graduação ${ }^{31}$ esclareceu que Santo Amaro era um campus avançado da UNIFESP, onde não foram criados novos departamentos, diferentemente, dos outros campi da expansão. (UNIFESP, Ata do CONSU de 12 de julho de 2006).

Após negociação e acordo com os líderes das comunidades locais, essa unidade foi concebida para ofertar os cursos de extensão, com a construção de um Centro de Convivência. (UNIFESP, Ata da reunião do CONSU de 4 de novembro de 2009).

A inauguração da Unidade Santo Amaro, do Campus São Paulo, ocorreu no dia 27 de maio de 2011, com a presença do então Magnífico Reitor ${ }^{32}$, do Ministro da Educação ${ }^{33}$, do Secretário da Educação Superior ${ }^{34}$ e do Prefeito de São Paulo ${ }^{35}$, demais autoridades e políticos da região. Nessa ocasião, o reitor destacou a parceria da prefeitura com a UNIFESP e o investimento de $R \$ 1,5$ milhões. (UNIFESP, Ata da reunião ordinária do Conselho Universitário da Universidade Federal de São Paulo de 8 de junho de 2011).

\footnotetext{
${ }^{31}$ Luiz Eugenio Araújo de Moraes Mello - Pró-Reitor de Graduação no período de 2005 a 2008

${ }^{32}$ Walter Manna Albertoni - Reitor da Universidade Federa de São Paulo no período de 2009 a 2013

${ }^{33}$ Fernando Haddad - Ministro da Educação no período de 2005 a 2012

${ }^{34}$ Luiz Claudio Costa - Secretário da Educação Superior no período de 2011 a 2012

${ }^{35}$ Gilberto Kassab - Prefeito da cidade de São Paulo no período de 2006 a 2013
} 
Iniciava-se, concomitantemente na universidade, a discussão do primeiro Plano de Desenvolvimento Institucional (PDI) da UNIFESP. Nesse plano, a universidade devia esclarecer, para o Estado e para a sociedade, os seus objetivos e projetos para os próximos cinco anos (2005-2010). Na universidade, a elaboração desse documento devia envolver diferentes atores institucionais e ser construído a partir de uma oficina de sensibilização para delineamento de suas linhas gerais, além de uma ampla pesquisa com a comunidade acerca do que se pretendia para o futuro da universidade. (UNIFESP, Ata CONSU de 13 de outubro de 2004).

Na elaboração do PDI (2005-2010) da UNIFESP, a comissão responsável direcionou as ações para a expansão de seu escopo enquanto universidade pública, a fim de colocar em prática as ideias de expansão das áreas do conhecimento que eram discutidas, na UNIFESP, por meio de debates.

Na discussão do processo de expansão, estava incluída a criação de novos campi, como o da Baixada Santista, com novos cursos da área tradicional da universidade, além de outros cursos de graduação e novas áreas do conhecimento. A ideia era que, inicialmente, os cursos a serem criados tivessem interface na área da saúde. Assim, utilizando-se as competências institucionais e a capacitação humana que a UNIFESP já apresentara.

O PDI trazia a implementação, para 2005, das Ações Afirmativas da Educação, com a expansão, em 10\%, da oferta do número de vagas da graduação para negros/pardos e indígenas, provenientes de escolas públicas. (UNIFESP, Plano de Desenvolvimento Institucional (PDI) 2005-2010. São Paulo, SP, 2005).

No decorrer da implantação desses primeiros campi, o reitor ${ }^{36}$ trouxe aos conselheiros do CONSU a notícia da criação de uma universidade na região do $A B C$ e que a UNIFESP havia declarado interesse em participar do processo. O Secretário da SESu ${ }^{37}$ à época, assim se manifestou:

\footnotetext{
${ }^{36}$ Ulysses Fagundes Neto - Reitor da UNIFESP no período de 2003-2008

${ }^{37}$ Nelson Maculan Filho - Secretário da Educação Superior no período de 2004 a 2006
} 
(...) para o MEC seria mais vantajoso a expansão da UNIFESP do que a criação de outra Universidade, pois geraria mais gastos, o que seria motivo de críticas no Estado de São Paulo como em outros estados, mas que também querem criar outras Universidades, porque somente $8 \%$ dos jovens estudam em universidades públicas. (Ata do CONSU de 10 de novembro de 2004).

Esse fato gerou uma ampla discussão entre os conselheiros. O então próreitor de extensão ${ }^{38}$, disse na ocasião "já somos universidade há 10 anos, precisamos crescer e contamos com profissionais competentes para tanto". Outro conselheiro comentou que "deveríamos aceitar o desafio, que o CONSU ficará diversificado com profissionais de várias áreas, mas temos de preservar a qualidade do ensino". Nessa reunião, o reitor afirmou que o processo continuaria, apenas, se a UNIFESP permanecesse na liderança do mesmo e com a garantia de implantá-lo com qualidade. Essa proposta foi colocada em votação e aprovada pelos conselheiros presentes, com uma abstenção. (UNIFESP, Ata do CONSU de 10 de novembro de 2004).

A partir de uma audiência com o Ministro da Educação, em março de 2005, foi afastada a possibilidade de participação da UNIFESP na implantação da Universidade do ABC. (UNIFESP, Ata do CONSU de 9 de março de 2005).

Em julho de 2005, foram discutidas as primeiras tratativas em relação a dois novos campi de expansão nos municípios de Diadema e de São José dos Campos. Em Diadema, o início do novo campus se deu a partir de um convite do então prefeito da cidade ${ }^{39}$ que assumia o compromisso de fazer a doação de uma área para a universidade implantar o novo campus. (UNIFESP, Ata da reunião do CONSU de 13 de julho de 2005).

O reitor informara que as negociações, em relação ao campus, estavam avançadas quanto à área, pois, incialmente, foi proposto um edifício que não se adequava às necessidades. Por esse motivo, o prefeito ofereceu à UNIFESP uma área de preservação ambiental com 375 mil m², próximo a represa Billings. No dia 7 de dezembro de 2005, houve uma solenidade, na Prefeitura Municipal de

\footnotetext{
${ }^{38}$ Walter Manna Albertoni - Pró-Reitor de Extensão no período de 2003 a 2008

${ }^{39}$ José de Fillipi Júnior - Prefeito da cidade de Diadema no período de 2001 a 2008
} 
Diadema, para a cessão do terreno. (UNIFESP, Ata da reunião do CONSU de 5 de outubro de 2005).

A aprovação dos seguintes cursos, para o campus, foi comunicada pelo próreitor de graduação ${ }^{40}$, após discussão no CONGRAD: Ciências Biológicas bacharelado, Engenharia Química, Farmácia e Bioquímica, Química. Em outubro de 2005, o reitor colocou em votação a implantação dos cursos que foram aprovados. $\mathrm{Na}$ ocasião, o reitor ressaltou que "aprovada a expansão para Diadema e Guarulhos com os cursos apresentados, que se consolide a universidade como o Brasil quer". (UNIFESP, Atas das reuniões do CONSU, de 5 de outubro e de 14 de dezembro de 2005).

No dia 1 de novembro, foram recebidos os primeiros 40 professores aprovados para o Campus Diadema (UNIFESP, Atas das reuniões do CONSU de 10 de maio, de 22 de junho e de 8 de novembro de 2006).

No dia 6 de março de 2007, teve início a graduação no campus, com 50 vagas para cada um dos cursos: Ciências Biológicas - bacharelado, Engenharia Química, Farmácia e Bioquímica e Química, sob a coordenação do diretor indicado ${ }^{41}$.

Em agosto de 2007, com a presença do Magnífico Reitor e do Prefeito de Diadema, ocorreu a cerimônia para assinatura da escritura de doação do prédio do Campus Diadema que já se encontrava em funcionamento. Era um terreno de $20 \mathrm{mil} \mathrm{m}^{2}$ (UNIFESP, Ata do CONSU de 12 de setembro de 2007).

Em relação à criação de um campus no município de São José dos Campos, o primeiro contato foi feito pelo prefeito ${ }^{42}$ para a implantação de um hospital e de um Instituto de Tecnologia, com a infraestrutura de pessoal oferecida pela prefeitura. (UNIFESP, Ata do CONSU de 13 de julho de 2005).

\footnotetext{
${ }^{40}$ Luiz Eugenio Araújo de Moraes Mello - Pró-Reitor de Graduação no período de 2005 a 2008

${ }^{41}$ Virginia Berlanga Campos Junqueira - Diretora do Campus Diadema no período de 2006 a 2014

${ }^{42}$ Eduardo Pedrosa Cury - Prefeito da cidade de São José dos Campos no período de 2005 a 2008 e 2009 a 2012
} 
Em agosto, o convênio com a Prefeitura Municipal de São José dos Campos foi assinado para a implantação de um Instituto de Biotecnologia, em uma área de 188 mil m². A partir de então, foi instituída uma comissão, no âmbito do CONSU, que estaria incumbida da elaboração do projeto para essa implantação. (UNIFESP, Ata do CONSU 10 de agosto de 2005).

Em abril de 2006, a prefeitura cedeu uma área com $188 \mathrm{mil} \mathrm{m}^{2}$ e $35 \mathrm{mil} \mathrm{m}^{2}$ de área construída, para que fosse implementada uma sede do Instituto de Tecnologia Biomédica. (UNIFESP, Ata da reunião do CONSU de 12 de abril de 2006).

O apoio inicial do MEC, para implantação de um Parque Tecnológico e do Campus de São José dos Campos, ocorreu em reunião com o Secretário da SESu ${ }^{43}$, com o pró-reitor de graduação ${ }^{44}$ e com o vice-prefeito de São José dos Campos ${ }^{45}$, em Brasília. (UNIFESP, Ata da reunião do CONSU de 13 de setembro de 2006).

Nesse campus, o primeiro curso de graduação implantado foi o de Ciências da Computação que contou com 50 vagas e teve início em 2007, com recursos disponibilizados pelo MEC, com ênfase na interface entre tecnologia e saúde. (UNIFESP, Ata da reunião do CONSU de 11 de outubro de 2006).

A implantação de um campus da UNIFESP em Guarulhos foi citada, pela primeira vez, pelo reitor em reunião do CONSU, de 14 de dezembro de 2005, no momento de aprovação dos cursos, juntamente com os, do Campus Diadema. Nas atas, não foi possível identificar como se deu a origem desse campus nem como foram as tratativas para sua viabilização e os atores sociais envolvidos. A aprovação da instalação do Campus Guarulhos, com sede no bairro dos Pimentas, foi efetivada por meio da Resolução № 32, de 15 de dezembro de 2005. Na resolução, foi aprovada a criação dos cursos de Ciências Sociais, Pedagogia, História e Filosofia (UNIFESP, 2005).

\footnotetext{
${ }^{43}$ Nelson Maculan Filho - Secretário da Educação Superior no período de 2004 a 2006

${ }^{44}$ Luiz Eugenio Araújo de Moraes Mello - Pró-Reitor de Graduação no período de 2005 a 2008

${ }^{45}$ Riugi Kogima - Vice-Prefeito da cidade de São José dos Campos no período de 2000 a 2004 e 2005 a 2008
} 
O convênio, realizado com a prefeitura, para gerenciar o Hospital Municipal, que seria construído em frente ao campus no Bairro dos Pimentas, foi assinado no dia 10 de abril de 2006. As atividades do Campus Guarulhos iniciaram no mês de junho. (UNIFESP, Ata da reunião do CONSU de 12 de abril de 2006).

Na reunião do CONSU de novembro de 2006, a Diretora Acadêmica do Campus de Guarulhos ${ }^{46}$ resgatou a história da constituição do campus. Comentou dois desafios nesse processo: a introdução de áreas do conhecimento diferentes das predominantes na UNIFESP até então e a implantação de cursos noturnos (ambos estranhos à cultura da UNIFESP). Pelo relato da professora, foi criada, em 2005, uma comissão na pró-reitoria de graduação, com a presença de professores das áreas de humanas da UNIFESP, para a discussão do modelo curricular dos cursos de Ciências Sociais, Filosofia, História e Pedagogia que foram aprovados pelo MEC. Destacou a proposta de implementação de dois eixos: um que garantisse uma formação sólida na área e outro que extrapolasse a área e preparasse o aluno para a interdisciplinaridade. Na ocasião, o reitor ressaltou que se havia passado de 5 cursos com 490 vagas, para 19 cursos com 1.150 vagas e que, no dia 1 de novembro de 2006, haviam sido recebidos os novos 40 professores do campus. (UNIFESP, Ata da reunião do CONSU de 8 de novembro de 2006).

O início do ano letivo do Campus Guarulhos ocorreu no dia 5 de março de 2007, com 50 vagas para cada um dos cursos aprovados. (UNIFESP, Ata da reunião do CONSU de 14 de março de 2007).

Na mesma reunião, o reitor informou a cerimônia de assinatura da escritura de área de 20 mil m$^{2}$, junto com o Prefeito do Município de Guarulhos ${ }^{47}$, onde se localizavam as salas de aula e o Teatro Adamastor Pimenta do Campus Guarulhos. (UNIFESP, Ata do CONSU de 12 de setembro de 2007).

\footnotetext{
${ }^{46}$ Cynthia Andersen Sarti - Diretora Acadêmica do Campus de Guarulhos no período de 2006 a 2009

${ }^{47}$ Elói Alfredo Pietá - Prefeito do Município de Guarulhos no período de 2001 a 2008
} 
No final do ano de 2007 a UNIFESP estava assim configurada, conforme demonstra o Quadro 7:

Quadro 7. Campi, cursos e vagas, de acordo com ano de criação

\begin{tabular}{|c|c|c|c|c|c|}
\hline \multirow{2}{*}{ Campus } & \multirow{2}{*}{ Criação } & \multirow{2}{*}{ Início } & \multirow{2}{*}{ Cursos } & \multicolumn{2}{|c|}{ Vagas } \\
\hline & & & & Período & $\mathbf{N}$ \\
\hline \multirow[t]{5}{*}{ Baixada Santista } & \multirow[t]{5}{*}{2005} & 2006 & Educação Física & Integral & 42 \\
\hline & & 2006 & Fisioterapia & Integral & 42 \\
\hline & & 2006 & Nutrição & Integral & 42 \\
\hline & & 2006 & Psicologia & Integral & 42 \\
\hline & & 2006 & Terapia Ocupacional & Integral & 32 \\
\hline \multicolumn{3}{|l|}{ Subtotal } & 5 & & 200 \\
\hline \multirow[t]{4}{*}{ Diadema } & \multirow[t]{4}{*}{2007} & 2007 & Ciências Biológicas & Integral & 50 \\
\hline & & 2007 & Engenharia Química & Integral & 50 \\
\hline & & 2007 & Farmácia e Bioquímica & Integral & 50 \\
\hline & & 2007 & Química & Integral & 50 \\
\hline \multicolumn{3}{|l|}{ Subtotal } & 4 & & 200 \\
\hline \multirow[t]{8}{*}{ Guarulhos } & \multirow[t]{8}{*}{2007} & 2007 & Ciências Sociais & Vespertino & 50 \\
\hline & & 2007 & Ciências Sociais & Noturno & 50 \\
\hline & & 2007 & Filosofia & Vespertino & 50 \\
\hline & & 2007 & Filosofia & Noturno & 50 \\
\hline & & 2007 & História & Vespertino & 50 \\
\hline & & 2007 & História & Noturno & 50 \\
\hline & & 2007 & Pedagogia & Vespertino & 50 \\
\hline & & 2007 & Pedagogia & Noturno & 50 \\
\hline \multicolumn{3}{|l|}{ Subtotal } & 8 & & 400 \\
\hline $\begin{array}{l}\text { São José dos } \\
\text { Campos }\end{array}$ & 2007 & 2007 & Ciência da Computação & Noturno & 50 \\
\hline \multicolumn{3}{|l|}{ Subtotal } & 1 & & 50 \\
\hline \multirow[t]{5}{*}{ São Paulo } & \multirow[t]{5}{*}{1933} & 1966 & Ciências Biomédicas & Integral & 33 \\
\hline & & 1939 & Enfermagem & Integral & 88 \\
\hline & & 1968 & Fonoaudiologia & Integral & 36 \\
\hline & & 1933 & Medicina & Integral & 121 \\
\hline & & 1970 & Tecnologia Oftálmica & Integral & 22 \\
\hline \multicolumn{3}{|l|}{ Subtotal } & 5 & & 300 \\
\hline \multicolumn{3}{|l|}{ TOTAL GERAL } & 23 & & 1.150 \\
\hline
\end{tabular}

Fonte: Quadro elaborado pela autora. 
Em síntese: no período de 2003 a 2007, a UNIFESP aumentou de 1 para 5 campi e contava com 273 vagas distribuídas em 5 cursos de graduação em 2004. Em 2005, o número de vagas aumentou em 10\%, devido ao Programa de Ações Afirmativas, passando para 300. Em 2006, com a expansão para o Campus Baixada Santista, a UNIFESP passou a ter 10 cursos e a ofertar 490 vagas, o que representou um aumento de $63 \%$. Em 2007, com a expansão para os campi de Diadema, Guarulhos e São José dos Campos, a UNIFESP passou a ofertar 1.150 vagas, distribuídas em 23 cursos, o que significou um aumento de 135\%. (UNIFESP, Balanço do Primeiro ano do REUNI da UNIFESP, de 31 de outubro de 2009). Este crescimento está demonstrado no Gráfico 9:

Gráfico 9. Crescimento do número de vagas ofertadas nos cursos na graduação, na UNIFESP

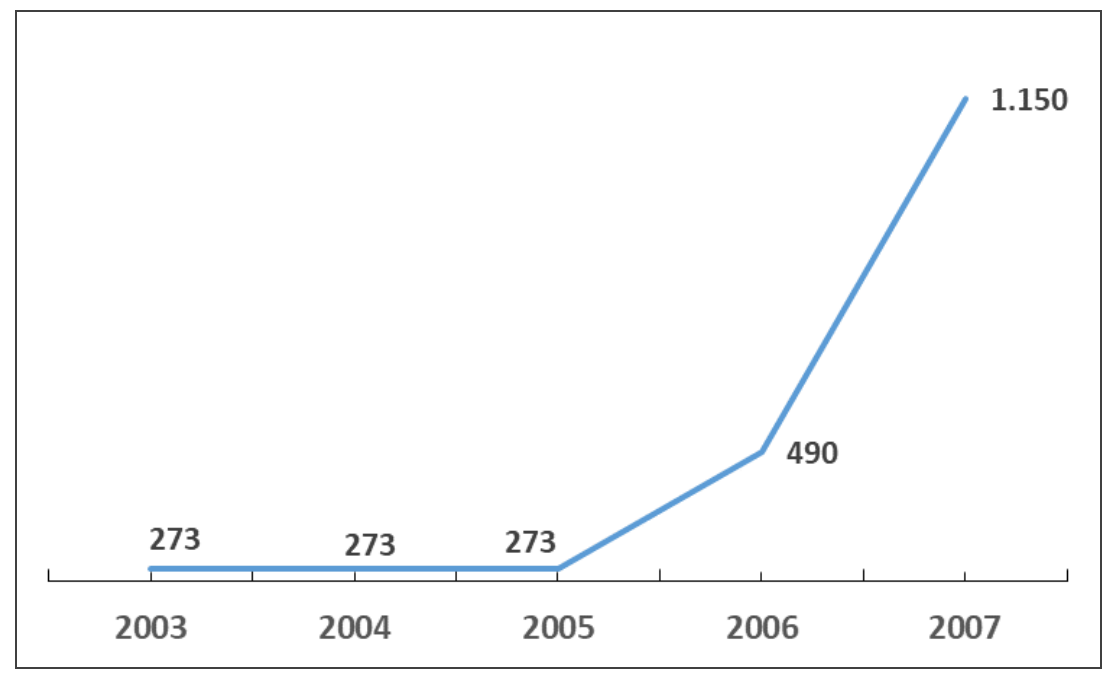

Fonte: Gráfico elaborado pela autora.

No período analisado, ocorreu um crescimento no número dos cursos de graduação na instituição: de 5 cursos em 2003, para 23, em 2007, num total de 18 cursos a mais. O Gráfico 10 mostra que, nos anos de 2003, 2004, o número de cursos se manteve, porém, de 2005 para 2006, o crescimento foi de 5 novos cursos e de 2006 para 2007 foi de 13. 
Gráfico 10. Crescimento do número de cursos na graduação, na UNIFESP

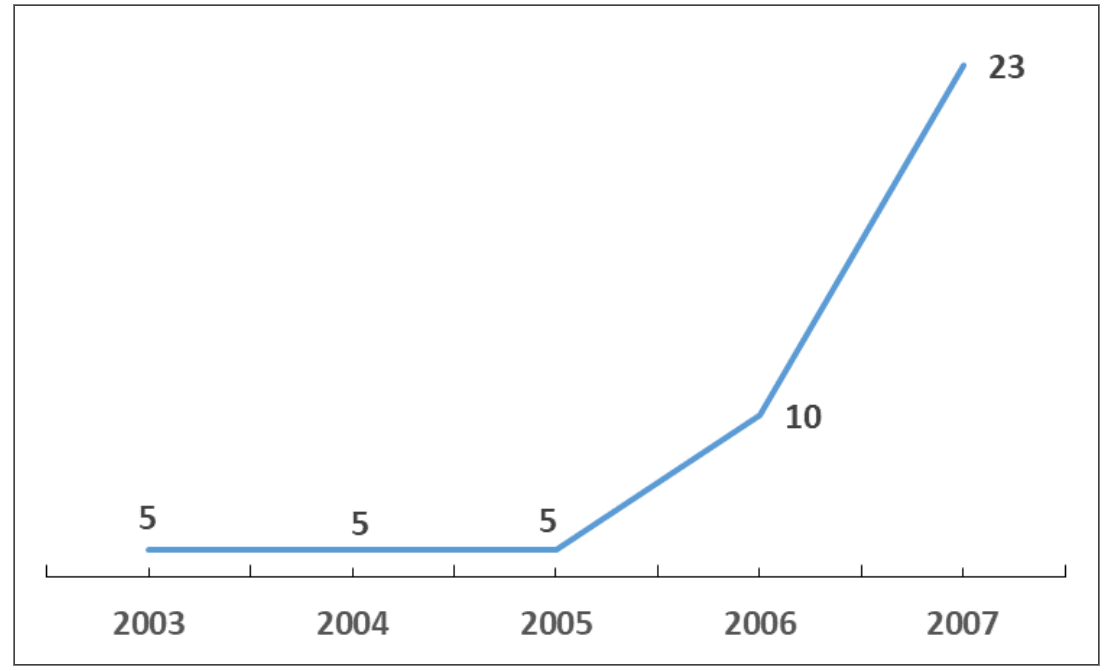

Fonte: Gráfico elaborado pela autora.

O Gráfico 11 demonstra o crescimento de 1.016 novas matrículas nos cursos de graduação, na primeira fase da expansão: de 1.296 matrículas em 2003, para 2.312, em 2007. Os dados mostraram um crescimento mais significativo de matrículas com o início de novos campi e cursos na UNIFESP: de 2005 para 2006 foram 217 matrículas e de 2006 para 2007, foram 776.

Gráfico 11. Crescimento do número de matrículas na graduação, na UNIFESP

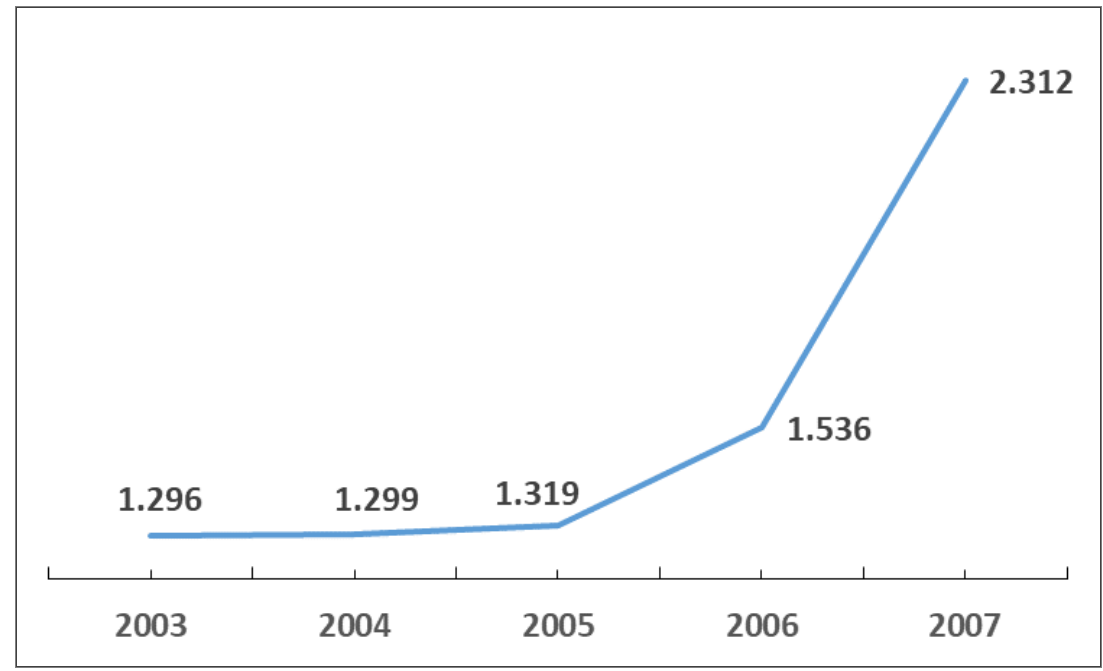

Fonte: Gráfico elaborado pela autora. 


\subsubsection{A segunda fase de expansão e o Programa de Apoio a Planos de Reestruturação e Expansão das Universidades Federais (REUNI) na UNIFESP (2008-2012)}

Em junho de 2007, o pró-reitor de graduação ${ }^{48}$ apresentou, na reunião do CONSU, o Programa de Apoio a Planos de Reestruturação e Expansão das Universidades Federais (REUNI). O professor informou que seria um programa de reestruturação das universidades públicas e ele foi publicado, pelo MEC, por meio do Decreto no 6.096, de 24 de abril de 2007. (UNIFESP, Ata do CONSU de 13 de junho de 2007).

O programa visava melhorar a taxa professor/aluno para 18 alunos por professor, incentivar a mobilidade estudantil e aumentar a vinculação entre a graduação e a pós-graduação. O pró-reitor também esclareceu que, no conjunto dos objetivos, constava o aumento do número de alunos, principalmente, no período noturno e o aumento do número de cursos. Salientou, ainda, a possibilidade de se conseguir um acréscimo de recursos para a instituição que poderia solicitar um aumento de $20 \%$ no número de servidores docentes e técnico-administrativos, bem como para a OCC e recursos para obras. Esses recursos deveriam ser solicitados mediante proposta institucional. O professor informou que a submissão de propostas deveria ocorrer até o mês de outubro de 2007. (UNIFESP, Ata do CONSU de 13 de junho de 2007).

Em outubro de 2007, o programa REUNI foi apresentado com maiores detalhes e com a proposta de adesão da UNIFESP. O pró-reitor de graduação ${ }^{49}$ esclareceu que a proposta havia sido fruto de uma série de reuniões, com início em abril no CONGRAD, com ampla discussão e participação dos membros desse conselho e com discussões nos campi da UNIFESP. (UNIFESP, Ata do CONSU de 17 de outubro de 2007).

\footnotetext{
${ }^{48}$ Luiz Eugenio Araújo de Moraes Mello - Pró-Reitor de Graduação no período de 2005 a 2008

${ }^{49}$ Luiz Eugenio Araújo de Moraes Mello - Pró-Reitor de Graduação no período de 2005 a 2008
} 
Nessa ocasião, ressaltou novamente as dimensões do REUNI para a reestruturação da educação superior pública: 1) o aumento de vagas de ingresso, especialmente no período noturno e redução das taxas de evasão; 2) a reestruturação acadêmica curricular; 3) a renovação pedagógica da educação superior; 4) a mobilidade intra e interinstitucional; 5) o compromisso social da Instituição e 6) o suporte da pós-graduação ao desenvolvimento e aperfeiçoamento qualitativo dos cursos de graduação. A proposta de adesão da UNIFESP ao programa, detalhada a seguir, foi colocada em votação e foi aprovada com 32 votos a favor, 4 votos contrários e 9 abstenções. (UNIFESP, Ata do CONSU de 17 de outubro de 2007).

De acordo com o documento "Programa de Apoio a Planos de Reestruturação e Expansão das Universidades Federais (REUNI) - Proposta de adesão". (UNIFESP, 2008), o projeto, encaminhado ao MEC, previa um aumento de 1.248 vagas nos vestibulares da UNIFESP que ficariam assim distribuídas: 53 em 2008, 625 em 2009, 370 em 2010 e 200 em 2011, o que significaria um aumento de 108\% em relação às vagas oferecidas no ano de 2007.

Na reunião de novembro de 2007, o pró-reitor de graduação comunicou 0 envio da proposta para o MEC, ocorrida no dia 29 de outubro de 2007. (UNIFESP, Ata do CONSU de 21 de novembro de 2007).

No vestibular 2008, foram acrescidas 50 vagas em uma turma do curso de Ciência da Computação, oferecida no período vespertino no Campus de São José dos Campos e mais 3 vagas, em cursos de Tecnologias em Saúde, no Campus São Paulo. Dessa maneira, as 22 vagas oferecidas para o curso de Tecnologia Oftálmica, existentes em 2007, passaram para 25 em 2008 e ficaram assim distribuídas: 9 vagas seriam destinadas para um novo curso de Tecnologia Radiológica e 16 vagas permaneceram no curso de Tecnologia Oftálmica.

No vestibular de 2009, foram acrescidas 625 novas vagas para os campi e ficariam assim distribuídas: Baixada Santista, 140; Diadema, 80; Guarulhos, 330; São José dos Campos, 50; e São Paulo, 25. Os cursos, os turnos e o número dessas vagas são apresentados no Quadro 8: 
Quadro 8. Previsão de cursos e novas vagas para 2009, por campus, na UNIFESP

\begin{tabular}{|c|c|c|c|c|c|}
\hline Campus & Curso & Período & 2008 & 2009 & Aumento \\
\hline \multirow{7}{*}{$\begin{array}{l}\text { Baixada Santista } \\
\text { Vagas } 2008=200 \\
\text { Vagas } 2009=340\end{array}$} & Educação Física & Integral & 42 & 50 & 8 \\
\hline & Fisioterapia & Integral & 42 & 50 & 8 \\
\hline & Nutrição & Integral & 42 & 50 & 8 \\
\hline & Psicologia & Integral & 42 & 50 & 8 \\
\hline & Serviço Social & Vespertino & - & 50 & 50 \\
\hline & Serviço Social & Noturno & - & 50 & 50 \\
\hline & Terapia Ocupacional & Integral & 32 & 40 & 8 \\
\hline \multicolumn{5}{|l|}{ Subtotal } & 140 \\
\hline \multirow{2}{*}{$\begin{array}{l}\text { Diadema } \\
\text { Vagas } 2008=200 \\
\text { Vagas } 2009=280\end{array}$} & Farmácia e Bioquímica & Noturno & - & 40 & 40 \\
\hline & Química Industrial & Noturno & - & 40 & 40 \\
\hline \multicolumn{5}{|l|}{ Subtotal } & 80 \\
\hline \multirow{11}{*}{$\begin{array}{l}\text { Guarulhos } \\
\text { Vagas } 2008=400 \\
\text { Vagas } 2009=730\end{array}$} & Ciências Sociais & Vespertino & 50 & 60 & 10 \\
\hline & Ciências Sociais & Noturno & 50 & 60 & 10 \\
\hline & Filosofia & Vespertino & 50 & 60 & 10 \\
\hline & Filosofia & Noturno & 50 & 60 & 10 \\
\hline & História & Vespertino & 50 & 60 & 10 \\
\hline & História & Noturno & 50 & 60 & 10 \\
\hline & História da Arte & Noturno & - & 50 & 50 \\
\hline & Letras & Vespertino & - & 100 & 100 \\
\hline & Letras & Noturno & - & 100 & 100 \\
\hline & Pedagogia & Vespertino & 50 & 60 & 10 \\
\hline & Pedagogia & Noturno & 50 & 60 & 10 \\
\hline \multicolumn{5}{|l|}{ Subtotal } & 330 \\
\hline $\begin{array}{l}\text { São Jose dos } \\
\text { Campos } \\
\text { Vagas } 2008=100 \\
\text { Vagas } 2009=150\end{array}$ & Matemática Computacional & Matutino & - & 50 & 50 \\
\hline \multicolumn{3}{|l|}{ Subtotal } & & & 50 \\
\hline \multirow{2}{*}{$\begin{array}{l}\text { São Paulo } \\
\text { Vagas } 2008=303 \\
\text { Vagas } 2009=328\end{array}$} & Tecnologia Oftálmica & Matutino & 16 & 25 & 9 \\
\hline & Tecnologia Radiológica & Matutino & 9 & 25 & 16 \\
\hline \multicolumn{5}{|l|}{ Subtotal } & 25 \\
\hline \multicolumn{5}{|l|}{ TOTAL GERAL } & 625 \\
\hline
\end{tabular}

Fonte: Quadro elaborado pela autora.

Na proposta, foi previsto um aumento de 320 vagas de ingresso em 9 cursos noturnos para o vestibular de 2009, o que significou: 50 vagas para o novo curso de Serviço Social, no Campus Baixada Santista; 40 vagas no curso de Farmácia e 
Bioquímica e 40 no curso de Química Industrial, no Campus Diadema; e 10 no curso de Ciências Sociais, 10, no de Filosofia, 10, no de História, 50, no novo curso de História da Arte, 100, no de Letras e 10 no de Pedagogia, no Campus Guarulhos. Desse modo, a UNIFESP, que em 2007 tinha 250 vagas em cursos noturnos, aumentaria esse número para 570 no final do programa REUNI, o que corresponderia a $128 \%$ do total de vagas oferecidas no vestibular.

Para o vestibular 2010, estava previsto um aumento de 370 novas vagas no Campus Diadema, conforme descrito no Quadro 9:

Quadro 9. Previsão de cursos e novas vagas para 2010, no Campus Diadema da UNIFESP

\begin{tabular}{|l|l|c|c|c|c|}
\hline Campus & Curso & Período & $\mathbf{2 0 0 9}$ & $\mathbf{2 0 1 0}$ & Aumento \\
\hline Diadema & Ciências Ambientais & Integral & - & 50 & 50 \\
\hline $\begin{array}{l}\text { Vagas 2009=280 } \\
\text { Vagas 2010=650 }\end{array}$ & Engenharia Química & Integral & 50 & 100 & 50 \\
\cline { 2 - 6 } & Farmácia e Bioquímica & Integral & 50 & 100 & 50 \\
\cline { 2 - 7 } & Farmácia e Bioquímica & Noturno & 40 & 50 & 10 \\
\cline { 2 - 7 } & $\begin{array}{l}\text { Licenciatura Plena em } \\
\text { Ciências }\end{array}$ & Vespertino & - & 100 & 100 \\
\cline { 2 - 7 } & $\begin{array}{l}\text { Licenciatura Plena em } \\
\text { Ciências }\end{array}$ & Noturno & - & 100 & 100 \\
\cline { 2 - 6 } & Química Industrial & Noturno & 40 & 50 & 10 \\
\hline TOTAL GERAL & & & & $\mathbf{3 7 0}$ \\
\hline
\end{tabular}

Fonte: Quadro elaborado pela autora.

Para o vestibular de 2011, a previsão foi um aumento de 200 novas vagas com a criação do Bacharelado em Ciências do Mar e Meio Ambiente (BICT-Mar) no Campus Baixada Santista.

O pró-reitor de graduação ${ }^{50}$ salientara que o número de cursos de graduação na UNIFESP seria amliado de 23 para 41 até 2012. Em relação ao número de vagas para ingresso, passaria de 1.150 para 2.398 e as vagas para os cursos noturnos, de 250 para 570 vagas. A projeção feita, à época, foi que em 2017 estar-se-ia com 10.487 alunos, em relação aos 2.312, de 2007. (UNIFESP, Ata do CONSU de 13 de fevereiro de 2008).

\footnotetext{
${ }^{50}$ Luiz Eugenio Araújo de Moraes Mello - Pró-Reitor de Graduação no período de 2005 a 2008
} 
A proposta para o REUNI considerou a expansão de vagas de 1.203 para o vestibular 2008, que foi cumprida em sua totalidade, conforme demonstra o Quadro 10:

Quadro 10. Distribuição das vagas de ingresso por campus, no ano de 2008, na UNIFESP

\begin{tabular}{|l|c|}
\hline Campus & Total \\
\hline Baixada Santista & 200 \\
\hline Diadema & 200 \\
\hline Guarulhos & 400 \\
\hline São José dos Campos & 100 \\
\hline São Paulo & 303 \\
\hline TOTAL & $\mathbf{1 . 2 0 3}$ \\
\hline
\end{tabular}

Fonte: Quadro elaborado pela autora.

Para o vestibular 2009, da previsão inicial de 1.828, foram oferecidas 1.812 vagas para os cursos de graduação, o que significou uma diferença de 16 vagas: no curso de Tecnologia Oftálmica, foram previstas 25 vagas, mas oferecidas 17 e no curso de Tecnologia em Radiologia, foram previstas 25 vagas, oferecidas 17 . 0 Quadro 11 demonstra a distribuição das vagas por campus:

Quadro 11. Distribuição das vagas de ingresso por campus, no ano de 2009, na UNIFESP

\begin{tabular}{|l|c|}
\hline Campus & Total \\
\hline Baixada Santista & 340 \\
\hline Diadema & 280 \\
\hline Guarulhos & 730 \\
\hline São José dos Campos & 150 \\
\hline São Paulo & 312 \\
\hline TOTAL & $\mathbf{1 . 8 1 2}$ \\
\hline
\end{tabular}

Fonte: Quadro elaborado pela autora.

Para o vestibular de 2010, a oferta de vagas foi de 2.198 (Quadro 12), cumpridas na sua totalidade. Naquele ano, foram oferecidos novos cursos para o Campus Diadema: o de Ciências Ambientais e o de Licenciatura Plena em Ciências: 
Quadro 12. Distribuição das vagas de ingresso por campus, no ano de 2010, na UNIFESP

\begin{tabular}{|l|c|}
\hline Campus & Total \\
\hline Baixada Santista & 340 \\
\hline Diadema & 650 \\
\hline Guarulhos & 730 \\
\hline São José dos Campos & 150 \\
\hline São Paulo & 328 \\
\hline TOTAL & $\mathbf{2 . 1 9 8}$ \\
\hline
\end{tabular}

Fonte: Quadro elaborado pela autora.

A oferta de vagas, no vestibular de 2011, foi de 2.348 (Quadro 13), cumpridas na sua totalidade. Na proposta do REUNI para o vestibular 2011, estavam previstas 2.398 vagas, aqui incluídas as 200 vagas para o BICT-MAR, no Campus Baixada Santista. Essas vagas não foram oferecidas naquele ano. Todavia, foram oferecidas 300 vagas para o Bacharelado em Ciência e Tecnologia, do Campus São José dos Campos, as quais não estavam previstas na proposta original.

Quadro 13. Distribuição de vagas de ingresso por campus, no ano de 2011, na UNIFESP

\begin{tabular}{|l|c|}
\hline Campus & Total \\
\hline Baixada Santista & 340 \\
\hline Diadema & 650 \\
\hline Guarulhos & 730 \\
\hline São José dos Campos & 300 \\
\hline São Paulo & 328 \\
\hline TOTAL & $\mathbf{2 . 3 4 8}$ \\
\hline
\end{tabular}

Fonte: Quadro elaborado pela autora.

A implantação do Bacharelado em Ciências do Mar e Meio Ambiente se deu em 2012 e as primeiras 200 vagas foram preenchidas no vestibular daquele ano.

O projeto preliminar de criação do Instituto de Ciências do Mar e do Meio Ambiente (ICMMA) foi elaborado por uma comissão presidida pelo Coordenador da Secretaria de Planejamento Acadêmico ${ }^{51}$ e apresentado à diretoria ${ }^{52}$ e a

\footnotetext{
${ }^{51}$ Nildo Alves Batista - Coordenador da Secretaria de Planejamento Acadêmico no período de abril a fevereiro de 2013

${ }^{52}$ Regina Célia Spadari - Diretora Acadêmica do Campus Baixada Santista no período de 2011 a 2015
} 
Congregação do Campus Baixada Santista na reunião do mês de novembro de 2011. (UNIFESP, Ata da reunião ordinária do CONSU, de 9 de novembro de 2011). O projeto foi aprovado em reunião do CONSU com 7 abstenções em março de 2007. (UNIFESP, Ata do CONSU de 14 de março de 2007). Em setembro de 2011, em reunião do CONSU, foi informada a criação dos cursos do instituto que haviam sido aprovados pelo MEC. Iniciou-se, assim, a implantação de um Bacharelado Interdisciplinar em Ciência e Tecnologia do Mar nos primeiros 3 anos, com a possibilidade de prosseguimento para as áreas de Engenharia do Petróleo e Energias Alternativas, Engenharia Ambiental e Portuária, Engenharia da Pesca e Aquicultura, Ecologia Marinha e Oceanografia. (UNIFESP, Ata da reunião ordinária do CONSU, de 14 de setembro de 2011).

A proposta do REUNI previa, para o ano de 2012, um total de 2.598 vagas. Para aquele ano, a oferta de vagas para o vestibular foi de 2.549 vagas e ficaram assim distribuídas nos campi: Baixada Santista 540 (Ciências da Saúde, 340 e BICT-Mar, 200); Diadema, 650; Guarulhos, 730; São José dos Campos, 300 e São Paulo, 329, conforme demonstra o Quadro 14:

Quadro 14. Distribuição de vagas de ingresso por campus, no ano de 2012, na UNIFESP

\begin{tabular}{|l|c|}
\hline Campus & Total \\
\hline Baixada Santista & 540 \\
\hline Diadema & 650 \\
\hline Guarulhos & 730 \\
\hline São José dos Campos & 300 \\
\hline São Paulo & 329 \\
\hline TOTAL & $\mathbf{2 . 5 4 9}$ \\
\hline
\end{tabular}

Fonte: Quadro elaborado pela autora.

Importante enfatizar que, para além do programa REUNI, a UNIFESP criou no período analisado mais um campus de expansão. O Campus Osasco iniciou suas atividades em 2012 com a oferta de 320 vagas nos cursos de: Administração (integral e noturno), Ciências Contábeis (integral e noturno), Ciências Econômicas (integral e noturno), Relações Internacionais (integral e noturno).

No final do ano de 2012 a UNIFESP estava assim configurada, conforme demonstra o Quadro 15: 
Quadro 15. Campus, cursos e vagas, de acordo com ano de criação

\begin{tabular}{|c|c|c|c|c|c|}
\hline \multirow{2}{*}{ Campus } & \multirow{2}{*}{ Criação } & \multirow{2}{*}{ Início } & \multirow{2}{*}{ Cursos } & \multicolumn{2}{|c|}{ Vagas } \\
\hline & & & & Período & $\mathbf{N}$ \\
\hline \multirow[t]{9}{*}{ Baixada Santista } & \multirow[t]{9}{*}{2005} & 2006 & Educação Física & Integral & 50 \\
\hline & & 2006 & Fisioterapia & Integral & 50 \\
\hline & & 2006 & Nutrição & Integral & 50 \\
\hline & & 2006 & Psicologia & Integral & 50 \\
\hline & & 2006 & Terapia Ocupacional & Integral & 40 \\
\hline & & 2009 & Serviço Social & Noturno & 50 \\
\hline & & 2009 & Serviço social & Vespertino & 50 \\
\hline & & 2012 & $\begin{array}{l}\text { Bacharelado Interdisciplinar em } \\
\text { Ciências do Mar }\end{array}$ & Noturno & 100 \\
\hline & & 2012 & $\begin{array}{l}\text { Bacharelado Interdisciplinar em } \\
\text { Ciências do Mar }\end{array}$ & Vespertino & 100 \\
\hline \multicolumn{3}{|l|}{ Subtotal } & 9 & & 540 \\
\hline \multirow[t]{10}{*}{ Diadema } & \multirow[t]{10}{*}{2007} & 2007 & Ciências Biológicas & Integral & 50 \\
\hline & & 2007 & Engenharia Química & Integral & 50 \\
\hline & & 2007 & Farmácia e Bioquímica & Integral & 50 \\
\hline & & 2007 & Química & Integral & 50 \\
\hline & & 2009 & Engenharia Química & Noturno & 50 \\
\hline & & 2009 & Farmácia e Bioquímica & Noturno & 100 \\
\hline & & 2009 & Química Industrial & Noturno & 50 \\
\hline & & 2010 & Ciências Ambientais & Integral & 50 \\
\hline & & 2010 & Licenciatura Plena em Ciências & Noturno & 100 \\
\hline & & 2010 & Licenciatura Plena em Ciências & Vespertino & 100 \\
\hline \multicolumn{3}{|l|}{ Subtotal } & 10 & & 650 \\
\hline \multirow[t]{17}{*}{ Guarulhos } & \multirow[t]{17}{*}{2007} & 2007 & Ciências Sociais & Noturno & 60 \\
\hline & & 2007 & Ciências Sociais & Vespertino & 60 \\
\hline & & 2007 & Filosofia & Noturno & 60 \\
\hline & & 2007 & Filosofia & Vespertino & 60 \\
\hline & & 2007 & História & Noturno & 60 \\
\hline & & 2007 & História & Vespertino & 60 \\
\hline & & 2007 & Pedagogia & Noturno & 60 \\
\hline & & 2007 & Pedagogia & Vespertino & 60 \\
\hline & & 2009 & História da Arte & Noturno & 50 \\
\hline & & 2009 & Letras - Português & Noturno & 25 \\
\hline & & 2009 & Letras - Português & Vespertino & 25 \\
\hline & & 2009 & Letras - Português/Espanhol & Noturno & 25 \\
\hline & & 2009 & Letras - Português/Espanhol & Vespertino & 25 \\
\hline & & 2009 & Letras - Português/Francês & Noturno & 25 \\
\hline & & 2009 & Letras - Português/Francês & Vespertino & 25 \\
\hline & & 2009 & Letras - Português/Inglês & Noturno & 25 \\
\hline & & 2009 & Letras - Português/Inglês & Vespertino & 25 \\
\hline \multicolumn{3}{|l|}{ Subtotal } & 17 & & 730 \\
\hline \multirow[t]{4}{*}{ Osasco } & \multirow[t]{4}{*}{2011} & 2012 & Administração & Noturno & 40 \\
\hline & & 2012 & Administração & Integral & 40 \\
\hline & & 2012 & Ciências Contábeis & Noturno & 40 \\
\hline & & 2012 & Ciências Contábeis & Integral & 40 \\
\hline
\end{tabular}




\begin{tabular}{|c|c|c|c|c|c|}
\hline \multirow{2}{*}{ Campus } & \multirow{2}{*}{ Criação } & \multirow{2}{*}{ Início } & \multirow{2}{*}{ Cursos } & \multicolumn{2}{|c|}{ Vagas } \\
\hline & & & & Período & $\mathbf{N}$ \\
\hline \multirow[t]{4}{*}{ Osasco } & \multirow[t]{4}{*}{2011} & 2012 & Ciências Econômicas & Noturno & 40 \\
\hline & & 2012 & Ciências Econômicas & Integral & 40 \\
\hline & & 2012 & Relações Internacionais & Noturno & 40 \\
\hline & & 2012 & Relações Internacionais & Integral & 40 \\
\hline \multicolumn{3}{|l|}{ Subtotal } & 8 & & 320 \\
\hline \multirow{3}{*}{$\begin{array}{l}\text { São José dos } \\
\text { Campos }\end{array}$} & \multirow[t]{3}{*}{2007} & 2007 & Ciência da Computação & Noturno & 50 \\
\hline & & 2009 & Matemática Computacional & Noturno & 50 \\
\hline & & 2011 & $\begin{array}{l}\text { Bacharelado em Ciência e } \\
\text { Tecnologia }\end{array}$ & Integral & 200 \\
\hline \multicolumn{3}{|l|}{ Subtotal } & 3 & & 300 \\
\hline \multirow[t]{7}{*}{ São Paulo } & \multirow[t]{7}{*}{1933} & 1966 & Ciências Biomédicas & Integral & 33 \\
\hline & & 1939 & Enfermagem & Integral & 88 \\
\hline & & 1968 & Fonoaudiologia & Integral & 36 \\
\hline & & 1933 & Medicina & Integral & 121 \\
\hline & & 1970 & Tecnologia Oftálmica & Integral & 17 \\
\hline & & 2008 & Tecnologia Radiológica & Matutino & 17 \\
\hline & & 2012 & Informática e Saúde & Matutino & 17 \\
\hline \multicolumn{3}{|l|}{ Subtotal } & 7 & & 329 \\
\hline \multicolumn{3}{|l|}{ TOTAL GERAL } & 54 & & 2.869 \\
\hline
\end{tabular}

Fonte: Quadro elaborado pela autora.

Em síntese: no período compreendido entre 2003 e 2007, a UNIFESP contava com 1.150 vagas, distribuídas em 23 cursos de graduação. No período entre 2008 e 2012, a UNIFESP passou para 54 cursos de graduação e um total de oferta de vagas de 2.869 vagas, apontando um aumento de $150 \%$ neste período.

Importante enfatizar que, além do pactuado no projeto REUNI da instituição, a UNIFESP criou mais 4 cursos distribuídos no Campus Osasco e o Bacharelado em Ciência e Tecnologia, no Campus São José dos Campos.

A ampliação de vagas no período de 2008 a 2012 foi consequência da criação dos seguintes cursos:

(a) Campus Baixada Santista: curso de Serviço Social (noturno e vespertino) e o curso de Bacharelado Interdisciplinar em Ciências do Mar (noturno e vespertino);

(b) Campus Diadema: curso de Ciências Ambientais (integral), de Farmácia e Bioquímica (noturno), de Química Industrial (noturno), de Licenciatura Plena em Ciências (noturno e vespertino);

(c) Campus de Guarulhos: curso de História da Arte (noturno), de Letras Português (noturno e vespertino), de Letras - Português/Espanhol (noturno e 
vespertino), de Letras - Português /Francês (noturno e vespertino), de Letras Português/Inglês (noturno e vespertino);

(d) Campus São José dos Campos: curso de Matemática Computacional (noturno) e de Bacharelado em Ciência e Tecnologia (integral);

(e) Campus São Paulo: curso de Tecnologia Radiológica (matutino) e de Tecnologia em Informática e Saúde (matutino);

(f) Campus de Osasco: curso de Administração (noturno e integral), de Ciências Contábeis (noturno e integral), de Ciências Econômicas (noturno e integral) e de Relações Internacionais (noturno e integral).

O Gráfico 12 mostra como foi a evolução de vagas ofertadas para alunos ingressantes nos cursos de graduação: de 2008 para 2009 foram de 609 vagas; de 2009 para 2010 foram de 386 vagas; de 2010 para 2011 foram de 150 vagas; e de 2011 para 2012 foram de 201 vagas.

Gráfico 12. Crescimento do número de vagas ofertadas nos cursos de graduação, na UNIFESP

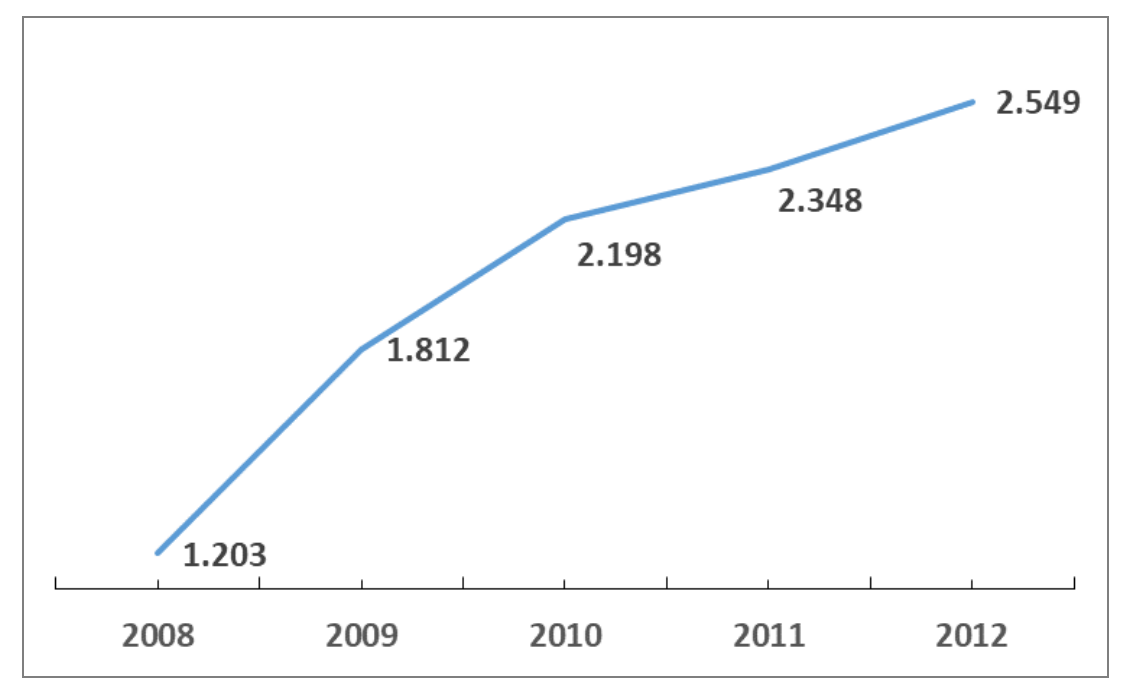

Fonte: Gráfico elaborado pela autora.

A partir dos editais dos concursos vestibulares, naquele período, os dados mostraram um crescimento de 29 no número de cursos de graduação (de 25 cursos em 2008 para 54 em 2012). 
A evolução de cursos de graduação é demonstrada pelo Gráfico 13 que de 2008 para 2009 foi de 13 cursos; de 2009 para 2010 de 4 cursos; no ano de 2011 o número se manteve em 42 cursos; e de 2011 para 2012 foi de 12 cursos.

Gráfico 13. Crescimento do número de cursos na graduação, na UNIFESP

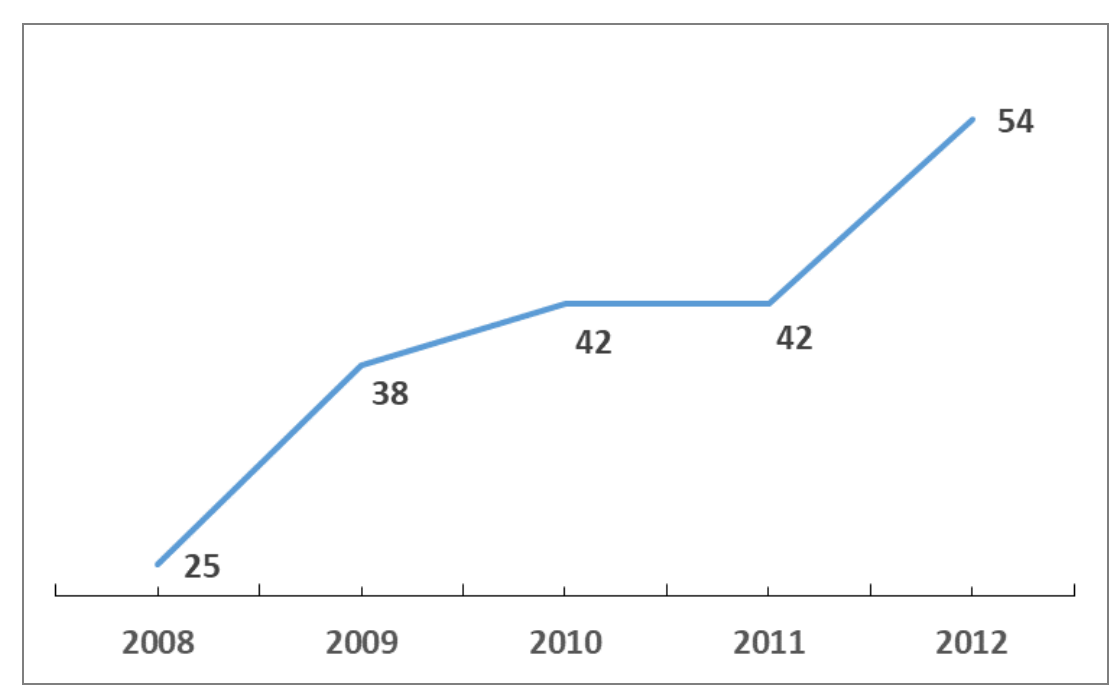

Fonte: Gráfico elaborado pela autora.

Nos relatórios de gestão de 2008 a 2012 e no documento "Balanço do Primeiro ano do REUNI da UNIFESP, de 31 de outubro de 2009 (UNIFESP, 2009), os dados mostraram, para esse período, um crescimento de 5.204 no número de matrículas na graduação, de 3.187 matrículas em 2008 para 8.391 em 2012.

A evolução do número de matrículas é demonstrada pelo Gráfico 14: de 2008 para 2009 foi de 1.293; de 2009 para 2010 foi de 1.466; de 2010 para 2011 foi de 133; e de 2011 para 2012 foi de 2.312. 
Gráfico 14. Crescimento do número de matrículas na graduação, na UNIFESP

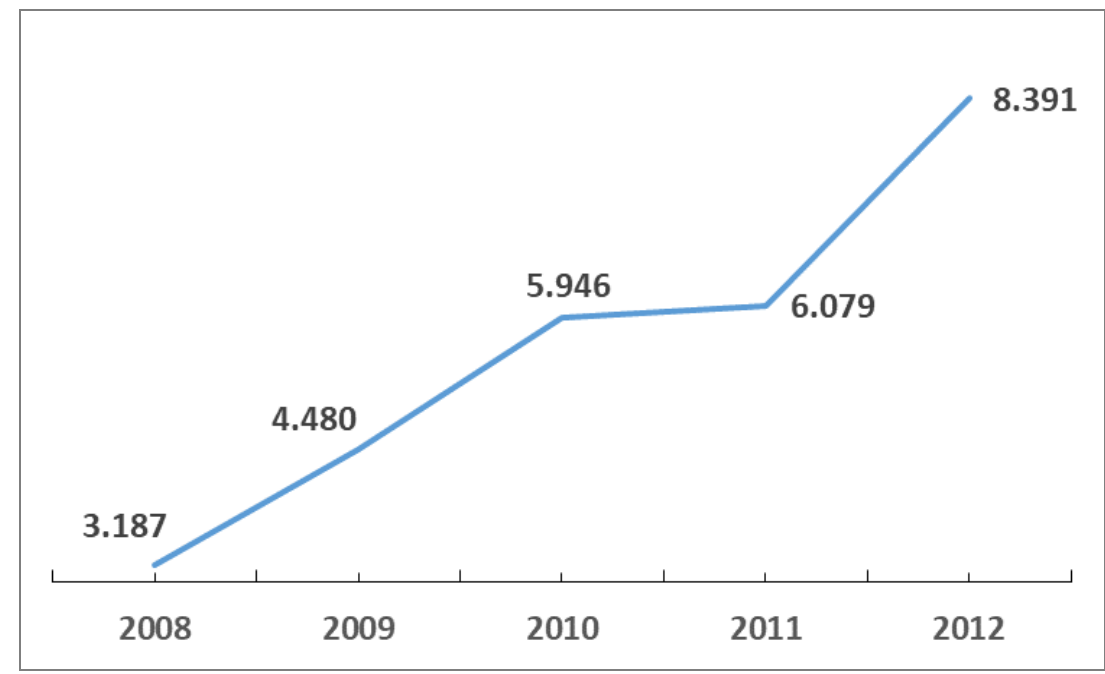

Fonte: Gráfico elaborado pela autora.

$\mathrm{Na}$ finalização desse capítulo, é importante observar o crescimento da UNIFESP nas duas fases da expansão, incluindo o Bacharelado em Ciência e Tecnologia do Campus de São José dos Campos e os cursos de graduação do Campus Osasco. O Quadro 16 demonstra a evolução, a partir dos dados quantitativos dos documentos analisados.

Quadro 16. Indicadores globais da primeira fase e da segunda fase da expansão da graduação na UNIFESP

\begin{tabular}{|c|c|c|c|c|c|}
\hline \multirow{2}{*}{ Indicadores } & \multicolumn{2}{|c|}{ Expansão $1^{\mathrm{a}}$ fase } & \multicolumn{2}{|c|}{ Expansão $2^{a}$ fase } & \multirow{2}{*}{$\%$ Global } \\
\hline & 2003 & 2007 & 2008 & 2012 & \\
\hline Campi & 1 & 5 & 5 & 6 & $500 \%$ \\
\hline Vagas de graduação & 273 & 1.150 & 1.203 & 2.869 & $834 \%$ \\
\hline Cursos de graduação & 5 & 23 & 25 & 54 & $980 \%$ \\
\hline Matrículas na graduação & 1.296 & 2.312 & 3.187 & 9.631 & $643 \%$ \\
\hline
\end{tabular}

Fonte: Quadro elaborado pela autora.

Esse fato significou um aumento percentual de 500\% no número de campi, $834 \%$ no número de vagas de ingresso, $980 \%$ no número de cursos e de $643 \%$ no número de matrículas. Além deste aumento quantitativo, a UNIFESP também diversificou sua área de atuação com a inclusão dos cursos de ciências humanas, sociais aplicadas e exatas. 


\section{CONSIDERAÇÕES FINAIS}

O processo de expansão da UNIFESP, ocorrido no período compreendido entre 2003 e 2012, pode ser considerado como único entre as IFES brasileiras, se for levado em conta o que ocorreu no ensino superior público federal no país. Em relação aos parâmetros nacionais, a sua singularidade se dá tanto pelo potencial transformador dessa expansão quanto pelo crescimento do número de campi, dos cursos e das matrículas de graduação.

Não se constituiu objeto desta pesquisa, a questão da dotação orçamentária, o crescimento de servidores (docentes e técnicos administrativos), bem como outros indicadores quantitativos referentes à pós-graduação, à pesquisa e à extensão. Procurou-se descrever esse processo com base nos dados quantitativos da graduação e analisá-lo de acordo com os principais elementos constitutivos da expansão no país.

A UNIFESP se tornou a primeira universidade brasileira especializada em saúde. Na ocasião de sua criação em 1994, abrigava cinco cursos de graduação em um único campus. Era uma universidade pública que tinha, por objetivo, desenvolver, em nível de excelência, atividades inter-relacionadas de ensino, de pesquisa e extensão, com ênfase no campo específico das ciências da saúde.

Em 2003, a UNIFESP, ainda como uma universidade temática da saúde, decidiu pelo aumento do número de vagas de graduação e se engajou no Programa de Expansão das Universidades Federais. Efetivamente, a etapa inicial desse processo de expansão começou em 2004, ano em que foi proposta, no CONSU, a criação do Campus Baixada Santista e da Unidade de Santo Amaro. A expansão estava voltada, até então, para aquelas áreas do conhecimento que dialogassem com os cursos e atividades em funcionamento no campo das ciências da saúde, por entender ser essa a expertise da instituição.

Com os novos campi, a contar do ano de 2007, a UNIFESP caminhou em direção às humanidades e a outras áreas, as quais, até aquele momento, não estavam presentes na instituição. Todavia, era necessário que essas novas áreas tivessem relação com as ciências da saúde. Começou, igualmente, a oferta de 
cursos noturnos, em cumprimento a uma das metas estabelecidas pelo governo federal.

A partir desse mesmo ano, o processo de expansão da UNIFESP foi dinâmico e significativo. As discussões no CONSU, órgão máximo da instituição na tomada de decisão, acerca da criação e implantação de novos campi (Baixada Santista, Diadema, Guarulhos, São José dos Campos e Osasco), bem como de novas áreas do conhecimento e cursos, foram marcadas por reuniões bastante dinâmicas, tornando-se assunto recorrente em todas as instâncias superiores da universidade.

Vale salientar que esse movimento de criação de novos campi e cursos ocorreu de maneira peculiar e acompanhou o processo de expansão das IFES, proposto pelo governo federal. Nesse sentido, observa-se que a criação e a implantação do Campus Baixada Santista foram discutidas de modo mais intenso, no decorrer dos anos de 2004 e 2005. Esse foi o primeiro campus fora da sede principal, o que levou à necessidade de mudança de estatuto.

Enquanto o Campus Baixada Santista caminhava para se concretizar, academicamente, surgiram novas possibilidades para a criação de novos campi nas cidades de Diadema, Guarulhos e São José dos Campos. Dessa vez, a discussão se deu de modo mais rápido nos conselhos superiores, devido à rapidez do processo geral de expansão das IFES e da necessidade de tomadas de decisão, no momento histórico pelo qual passava o país.

Para que se entenda a dimensão da expansão da UNIFESP na primeira fase, compreendida entre 2003 e 2007, faz-se necessária a comparação do seu crescimento em relação ao crescimento das demais universidades federais. A UNIFESP teve um crescimento de $400 \%$ no número de campi, enquanto, no Brasil, o crescimento total de campi nas universidades federais foi de $53 \%$. O número de vagas de graduação aumentou em $321 \%$ na UNIFESP e 53\% em nível nacional, nas IFES. O aumento do número de cursos da UNIFESP foi de $360 \%$ e, do total das universidades federais, foi de $28 \%$.

Numa perspectiva regional, o crescimento do número de campi da UNIFESP na primeira fase da expansão correspondeu a $20 \%$ do total de campus criados em toda a região sudeste (aumento de 1 para 5 campi). 
Por intermédio da proposta do REUNI (2008 a 2012), o crescimento no número de cursos de graduação na UNIFESP foi de $116 \%$. Ademais, mesmo sem fazer parte dessa proposta de adesão, a instituição criou, ainda, o Campus de Osasco e o Bacharelado em Ciência e Tecnologia, no Campus de São José dos Campos. Nesse período, o crescimento do número de cursos de graduação, nas universidades federais em geral, foi de $66 \%$.

Quanto ao crescimento global da UNIFESP, no período compreendido entre 2003 e 2012, os dados demonstraram um aumento de 500\% no número de campi e de $980 \%$ no número de cursos, o que significou um aumento global de $834 \%$ no número de vagas ofertadas pela instituição. No que se refere ao aumento global das universidades federais nesse período, os dados mostraram que foi de $106 \%$, no número de campi; $125 \%$, no número de cursos; e de $112 \%$, no número de vagas de ingresso.

Observa-se que a UNIFESP se empenhou em consolidar seus campi e cursos por meio de implementação de propostas pedagógicas inovadoras, bem como da diversificação de suas áreas de atuação. Assim, aumentou sua área de conhecimento, das ciências da saúde para as ciências humanas, sociais aplicadas e exatas.

No cenário da expansão no Brasil, é importante salientar a relevância da UNIFESP como uma das universidades que mais cresceu, pois, além de ampliar o número de campi, de vagas e de cursos, a instituição também diversificou sua área de atuação na graduação.

Apesar do ritmo intenso da expansão, considera-se que esta proporcionou à UNIFESP a oportunidade da interiorização e da ampliação do seu compromisso social, como uma universidade pública e, socialmente, referenciada. Além de expandir, consideravelmente, o número de vagas e a possibilidade de escolha de diferentes áreas profissionais, a universidade implantou o ensino noturno, tão necessário para a sociedade.

Observa-se, claramente, o caráter transformador que a expansão trouxe para a UNIFESP que, saiu de uma universidade da área da saúde para uma universidade plena. 
A realização desta pesquisa, proporcionou a satisfação de buscar e de analisar cada documento, de perceber e de rever a importância que o processo de expansão teve para as universidades brasileiras, principalmente, para a UNIFESP.

Entende-se que os momentos, vivenciados durante a pesquisa, contribuíram, outrossim, para um sentimento de não cumprimento do objeto proposto, na sua totalidade. Os resultados apontam para a magnitude do movimento da instituição, mesmo em um curto espaço de tempo, em relação a uma expansão dessa importância.

Apesar de todos os desafios, que até o momento a instituição enfrenta para a implantação plena de todo esse processo, o que não constituiu objeto desta investigação, pode-se considerá-lo vitorioso, pois todos os indicadores, tanto nacionais como internacionais, colocam a UNIFESP entre uma das melhores universidades do país, na atualidade. 


\section{REFERÊNCIAS}




\section{REFERÊNCIAS}

ASSOCIAÇÃO NACIONAL DOS DIRIGENTES DAS INSTITUIÇÕES FEDERAIS DE ENSINO SUPERIOR. Reforma Universitária: proposta da Andifes para a reestruturação da Educação Superior no Brasil. Maio de 2004. Disponível em: http://www.andifes.org.br/wp-content/files_flutter/1364828028PropostaAndifes.pdf. Acesso em: 15 abr. 2016.

ASSOCIAÇÃO NACIONAL DOS DIRIGENTES DAS INSTITUIÇÕES FEDERAIS DE ENSINO SUPERIOR. Consolidação dos dados acadêmicos, orçamentários e de pessoal referentes aos acordos de metas do Programa de Apoio a Planos de Reestruturação das Universidades - REUNI. [Relatório de Consultoria de Maria leda Costa Diniz]. Brasília (DF). Outubro de 2009. Disponível em:

http://www.andifes.org.br/wp-

content/files_flutter/Relatorio\%20do\%20periodo_maio\%20a\%20outubro\%20de\%202 009\%20-\%20REUNi\%20-\%20Consultora\%20Maria\%20leda.doc. Acesso em: 15 abr. 2016.

ASSOCIAÇÃO NACIONAL DOS DIRIGENTES DAS INSTITUIÇÕES FEDERAIS DE ENSINO SUPERIOR. Relatório de Acompanhamento do Programa de Apoio a Planos de Reestruturação e Expansão das Universidades Federais - REUNI. Brasília (DF): ANDIFES, jan. 2010.

ARAÚJO, C. et al. Estudo de Caso. Métodos de Investigação em Educação. Instituto de Educação e Psicologia, Universidade do Minho, 2008. Disponível em: <http://grupo4te.com.sapo.pt/estudo_caso.pdf>. Acesso em: 21 out. 2014.

BARDIN, L. Análise de conteúdo. 5. ed. Edições 70, Brasil, 2009.

BRASIL. Decreto no 8.659 de 5 de abril de 1911. Aprova a Lei Orgânica do Ensino Superior e do Fundamental na República. Disponível em: <http://www2.camara.leg.br/legin/fed/decret/1910-1919/decreto-8659-5-abril-1911517247-publicacaooriginal-1-pe.html>. Acesso em: 21 out. 2014.

BRASIL. Decreto no 11.530 de 18 de março de 1915. Reorganiza o ensino secundário e o superior na República. Disponível em: $<$ https://repositorio.ufsc.br/bitstream/handle/123456789/104708/1915\%20$\% 20$ Decreto\%2011530\%20$\% 20$ Reforma\%20Carlos\%20Maximiliano.pdf?sequence=1 >. Acesso em: 21 out. 2014. 
BRASIL. Decreto no 16.782-A de 13 de janeiro de 1925. Estabelece o concurso da União para a difusão do ensino primário, organiza o Departamento Nacional do Ensino, reforma o ensino secundário e o superior e dá outras providencias.

Disponível em:

<https://repositorio.ufsc.br/bitstream/handle/123456789/104707/1925_Decreto\%2016 782A_13\%20de\%20janeiro.pdf?sequence=1\&isAllowed=y>. Acesso em: $14 \mathrm{dez}$. 2014.

BRASIL. Decreto no 19.402 de 14 de novembro de 1930. Cria uma Secretária de Estado com a denominação de Ministério dos Negócios da Educação e Saúde Pública. Disponível em: http://www2.camara.leg.br/legin/fed/decret/19301939/decreto-19402-14-novembro-1930-515729-publicacaooriginal-1-pe.html. Acesso em: 14 dez. 2014.

BRASIL. Decreto oㅜ 19.850 de 11 de abril de 1931a. Cria o Conselho Nacional de Educação. Disponível em: <http://www2.camara.leg.br/legin/fed/decret/19301939/decreto-19850-11-abril-1931-515692-publicacaooriginal-1-pe.html>. Acesso em: 14 dez. 2014.

BRASIL. Decreto no 19.851 de 11 de abril de 1931b. Dispõe que o ensino superior no Brasil obedecerá de preferência, ao sistema universitário, podendo ainda ser ministrado em institutos isolados, e que a organização técnica e administrativa das universidades é instituída no presente decreto, regendo-se os institutos isolados pelos respectivos regulamentos, observados os dispositivos do seguinte Estatuto das Universidades Brasileiras. Disponível em:

<http://www2.camara.leg.br/legin/fed/decret/1930-1939/decreto-19851-11-abril-1931505837-publicacaooriginal-1-pe.html>. Acesso em: 22 jan. 2015.

BRASIL. Decreto № 19.852 de 11 de abril de 1931c. Dispõe sobre a organização da Universidade do Rio de Janeiro. Disponível em:

<http://www2.camara.leg.br/legin/fed/decret/1930-1939/decreto-19852-11-abril-1931510363-republicacao-85622-pe.html>. Acesso em: 23 jan. 2015.

BRASIL. Decreto-Lei no 4.048 de 22 de janeiro de 1942. Cria o Serviço Nacional de Aprendizagem dos Industriários (SENAI). Disponível em:

<http://www.planalto.gov.br/ccivil_03/decreto-lei/1937-1946/Del4048.htm>. Acesso em: 23 jan. 2015.

BRASIL. Constituição dos Estados Unidos do Brasil, de 18 de setembro de 1946a. Disponível em:

<http://www2.senado.leg.br/bdsf/bitstream/handle/id/139953/Constituicoes_Brasileira s_v5_1946.pdf?sequence=9 >. Acesso em: 23 jan. 2015. 
BRASIL. Decreto-Lei no 8.621 de 10 de janeiro de 1946b. Dispõe sobre a criação do Serviço Nacional de Aprendizagem Comercial (SENAC) e dá outras providências. Disponível em: <http://www.planalto.gov.br/ccivil_03/decreto-lei/19371946/Del8621.htm> Acesso em: 14 fev. 2015.

BRASIL. Lei de Diretrizes e Bases no 4.024 de 20 de dezembro de 1961. Fixa as Diretrizes e Bases da Educação Nacional. Disponível em: <http://www.planalto.gov.br/ccivil_03/leis//4024.htm>. Acesso em: 14 fev. 2015.

BRASIL. Conselho Federal de Educação. Parecer no 977 de 3 de dezembro de 1965. Definição dos cursos de pós-graduação. Disponível em: $<$ https://www.capes.gov.br/images/stories/download/legislacao/Parecer_CESU_977_ 1965.pdf>. Acesso em: 18 fev. 2015.

BRASIL. Lei no 5.540 de 28 de novembro de 1968. Fixa normas de organização e funcionamento do ensino superior e sua articulação com a escola média, e dá outras providências. Disponível em: <http://www.planalto.gov.br/ccivil_03/leis//5540.htm>. Acesso em: 18 fev. 2015.

BRASIL. Decreto-Lei no 464 de 11 de fevereiro de 1969. Estabelece normas complementares à Lei no 5.540 , de 28 de novembro de 1968, e dá outras providências. Disponível em: <http://www.planalto.gov.br/ccivil_03/decreto-lei/19651988/Del0464.htm>. Acesso em: 22 fev. 2015.

BRASIL. Lei no 5.692 de 11 de agosto de 1971. Fixa Diretrizes e Bases para o ensino de $1^{\circ}$ e $2^{\circ}$ graus, e dá outras providências. Disponível em:

<http://www.planalto.gov.br/ccivil_03/leis/15692.htm>. Acesso em: 22 fev. 2015.

BRASIL. Constituição da República Federativa do Brasil de 1988. Disponível em: <http://www.planalto.gov.br/ccivil_03/constituicao/constituicao.htm>. Acesso em: 15 abr. 2015.

BRASIL. Lei no 9.394 de 20 de dezembro de 1996. Estabelece as diretrizes e bases da educação nacional. Disponível em:

<https://www.planalto.gov.br/ccivil_03/Leis/L9394.htm>. Acesso em: 15 abr. 2015.

BRASIL. Edital no 4 de 10 de dezembro de 1997. Diário Oficial da União de 12 de dezembro de 1997, p.26920, seção III. Disponível em.

<http://portal.mec.gov.br/sesu/arquivos/pdf/e04.pdf>. Acesso em: 15 abr. 2015.

BRASIL. Lei no 10.172, de 9 de janeiro de 2001a. Aprova o Plano Nacional de Educação e dá outras providencias. Diário Oficial da União, Brasília, DF, 10 jan. 2001. PNE - 2001-2010. Disponível em: < http://www.planalto.gov.br/ccivil_03/leis/leis_2001/l10172.htm>. Acesso em: 22 abr. 2015. 
BRASIL. Constituições Brasileiras: 1824. vol. I. Brasília: Senado Federal e Ministério da Ciência e Tecnologia, Centro de Estudos Estratégicos, 2001b. Disponível em: <http://www2.senado.leg.br/bdsf/bitstream/handle/id/137569/Constituicoes_Brasileira s_v1_1824.pdf?sequence=5>. Acesso em: 16 jan. 2015.

BRASIL. Presidência da República. Grupo de trabalho interministerial. Bases para o enfrentamento da crise emergencial das universidades federais e roteiro para a reforma universitária brasileira. Brasília: [s.n.], 15 de dezembro de 2003a.

BRASIL. Decreto de 20 de dezembro de 2003. Institui Grupo de Trabalho Interministerial encarregado de analisar a situação atual e apresentar plano de ação visando a reestruturação, desenvolvimento e democratização das Instituições Federais de Ensino Superior (IFES). 2003b. Disponível em:

<http://www.sintunesp.org.br/refuniv/GT-Interministerial\%20-\%20Estudo.htm>. Acesso em: 23 out. 2015.

BRASIL. Ministério da Educação. Reforma da Educação Superior. Documento II. Reafirmando princípios e consolidando diretrizes da Reforma da Educação Superior. Brasília, 2 de agosto de 2004a.

BRASIL. Lei no 10.861 de 14 de abril de 2004b. Institui o Sistema Nacional de Avaliação da Educação Superior (SINAES) e dá outras providências. Disponível em: <http://www.planalto.gov.br/ccivil_03/_ato2004-2006/2004/lei/l10.861.htm>. Acesso em: 22 jun. 2015.

BRASIL. Portaria no 2.051 de 9 de julho de 2004c. Regulamenta os procedimentos de avaliação do Sistema Nacional de Avaliação da Educação Superior (SINAES), instituído na Lei no 10.861, de 14 de abril de 2004. Disponível em:

<http://portal.mec.gov.br/arquivos/pdf/PORTARIA_2051.pdf>. Acesso em: 22 jun. 2015.

BRASIL. Lei no 11.096 de 13 de janeiro de 2005. Institui o Programa Universidade para Todos (PROUNI), regula a atuação de entidades beneficentes de assistência social no ensino superior; altera a Lei № 10.891, de 9 de julho de 2004, e dá outras providências. Disponível em: <http://www.planalto.gov.br/ccivil_03/_ato20042006/2005/lei/L11096.htm>. Acesso em: 22 jun. 2015.

BRASIL. Ministério da Educação. Expansão das Universidades Federais, o sonho se torna realidade! Período 2003 a 2006. Coordenação geral: Maria leda Costa Diniz. Brasília, s/d. 2006a. 
BRASIL. Decreto no 5.773 de 9 de maio de 2006b. Dispõe sobre o exercício das funções de regulação, supervisão e avaliação de instituições de educação superior e cursos superiores de graduação e sequenciais no sistema federal de ensino.

Disponível em: http://www.planalto.gov.br/ccivil_03/_Ato20042006/2006/Decreto/D5773.htm\#art79. Acesso em: 15 mar. 2015.

BRASIL. Ministério da Educação. Projeto de Lei n 7.200, de 12 junho de 2006c. Estabelece normas gerais da educação superior, regula a educação superior no sistema federal de ensino, altera as Leis nos 9.394, de 20 de dezembro de 1996; 8.958, de 20 de dezembro de 1994; 9.504, de 30 de setembro de 1997; 9.532, de 10 de dezembro de 1997; 9.870, de 23 de novembro de 1999; e dá outras providências. Disponível em:

http://www.camara.gov.br/proposicoesWeb/prop_mostrarintegra;jsessionid=2A9699F 64289D4699440CE88DB2636F5. proposicoesWebExterno1?codteor=402692\&filena $\mathrm{me}=\mathrm{PL}+7200 / 2006$. Acesso em: 25 out. 2015.

BRASIL. Ministério da Educação. O Plano de Desenvolvimento da Educação. Razões, Princípios e Programas. Brasília, 24 de abril de 2007a. Disponível em: http://portal.mec.gov.br/arquivos/livro/livro.pdf. Acesso em: 10 jun. 2015.

BRASIL. Decreto no 6.096 de 24 de abril de 2007b. Institui o Programa de Apoio a Planos de Reestruturação e Expansão das Universidades Federais (REUNI). 2007b. Disponível em: <http://www.planalto.gov.br/ccivil_03/_ato20072010/2007/decreto/d6096.htm>. Acesso em: 10 jun. 2015.

BRASIL. Ministério da Educação. REUNI: reestruturação e expansão das universidades federais: diretrizes gerais. Documento Elaborado pelo Grupo Assessor nomeado pela Portaria no 552 SESu/MEC, de 25 de junho de 2007c, em complemento ao art. 1요 $2^{\circ}$ do Decreto Presidencial oㅡ 6.096, de 24 de abril de 2007. Brasília, DF: MEC, 2007c. Disponível em: http://portal.mec.gov.br/sesu/arquivos/pdf/diretrizesreuni.pdf. Acesso em: 11 jun. 2015.

BRASIL. Ministério da Educação. Programa de Apoio a Planos de Reestruturação e Expansão das Universidades Federais. Reuni 2008 - Relatório de Primeiro Ano. Brasília (DF), 30 de outubro de 2009. Disponível em: http://portal.mec.gov.br/index.php?option=com_docman\&view=download\&alias=2069 -reuni-relatorio-pdf\&ltemid=30192. Acesso em: 26 out. 2015.

BRASIL. Ministério da Educação. Relatório da Comissão Constituída pela Portaria no 126/2012 para Análise sobre a Expansão das Universidades Federais 2003 a 2012, 2012a. Disponível em: http://www.andifes.org.br/wpcontent/files_flutter/1361475592UFMT_-_Maria_Lucia_Neder__Relatorio_REUNI.pdf. Acesso em: 15 jun. 2015. 
BRASIL. Ministério da Educação. Análise sobre a Expansão das Universidades Federais 2003 a 2012. 2012b. Disponível em:

http://portal.mec.gov.br/index.php?option=com_docman\&view=download\&alias=1238 6-analise-expansao-universidade-federais-2003-2012-pdf\&Itemid=30192. Acesso em: 23 ago. 2015.

BRASIL. Ministério da Educação. A democratização e expansão da educação superior no país 2003 - 2014. Balanço das principais políticas e programas. Brasília, 2015[?]. Disponível em:

http://portal.mec.gov.br/index.php?option=com_docman\&view=download\&alias=1676 2-balanco-social-sesu-2003-2014\&ltemid=30192. Acesso em: 14 dez. 2015.

BRAVO, R. S. Técnicas de investigação social: Teoria e ejercicios. 7 ed. Ver. Madrid: Paraninfo, 1991.

CALADO, S.S; FERREIRA, S.C.R. Análise de documentos: método de recolha e análise de dados. 2004. Disponível em:

http://www.educ.fc.ul.pt/docentes/ichagas/mi1/analisedocumentos.pdf. Acesso em: 10 set. 2015.

CATANI, A.M.; OLIVEIRA, J.F. Educação superior no Brasil: reestruturação e metamorfose das universidades públicas. Petrópolis: Vozes, 2002.

CASTRO, C. M. Despertar do gigante com menos ufanismo e mais direção. A educação brasileira acorda. Belo Horizonte: Editora e Distribuidora Universal, 2003.

CELLARD, A. A análise documental. In: POUPART, J. et al. A pesquisa qualitativa: enfoques epistemológicos e metodológicos. Petrópolis, Vozes, 2008.

CHAGAS, V. Didática Especial de Línguas Modernas. São Paulo: Companhia Editora Nacional, 1979.

COLOMBO, S. S.; CARDIM, P. G. Nos Bastidores da Educação Brasileira: A Gestão Vista por Dentro. 1ํㅡㄹ ed., Editora Artmed, 2010. 320.

CURI, L. R. L. O paroxismo da qualidade: avaliação da educação superior no Brasil. Campinas, SP: [s.n.], 2011. Tese (Doutorado) - Universidade Estadual de Campinas, Instituto de Economia.

CURY, C. R. J. Quadragésimo ano do parecer CFE no 977/65. Revista Brasileira de Educação, Set /Out /Nov /Dez 2005 Nº 30.

DEMO, P. A nova LDB: ranços e avanços. 13 ed. Campinas, SP: Papirus, 2002. 
DURHAM, E. Educação superior, pública e privada (1808 - 2000). In:

SCHWARTMAN, Simon e BROCK, Colin. Os desafios da educação no Brasil. Rio de Janeiro. Nova Fronteira. 2005. p.197-240

FÁVERO, M. L. A. Universidade e Poder. Análise Crítica e fundamentos Históricos (1930-1945). Rio de Janeiro: Achiamé, 1980.

FÁVERO, M. L. A. A universidade no Brasil: das origens à Reforma Universitária de 1968. Educ. rev.[online]. 2006, n.28, pp. 17-36. ISSN 0104-4060.

FERRARI, A. T. Metodologia da pesquisa científica. São Paulo: McGraw-Hill do Brasil, 1982.

FREIRE, A. M. A. Analfabetismo no Brasil: da ideologia da interdição do corpo à ideologia nacionalista, ou de como deixar sem ler e escrever desde as Catarinas (Paraguaçu), Filipinas, Madalenas, Anas, Genebras, Apolônias e Grácias até os Severinos. 2. ed. São Paulo: Cortez, 1993.

FRANCO, M.L.P. B. Análise de conteúdo. 4ªํㅡㄹ. Brasília: Liber Livro Editora, 2012.

FRAUCHES, C. C.; FAGUNDES, G. M. LDB anotada e comentada e reflexões sobre a educação superior. 2ª Edição Revista e Atualizada. Brasília, DF: ILAPE, 2007. Disponível em:

<http://ava.unit.br/dokeos/conteudo/biblioteca_pos/POS2092ELEDU/LDB_2007versao_final-150507.pdf>. Acesso em: 15 dez. 2014.

FRAUCHES, C. C. A livre iniciativa e reforma universitária brasileira. Texto on line. Florianópolis: UFSC, s/d. Disponível em:

https://repositorio.ufsc.br/handle/123456789/35656?show=full. Acesso em: 25 mar. 2015.

GIL, A. C. Métodos e técnicas de pesquisa social. 5.ed. São Paulo: Atlas, 1999.

GIL, A. C. Como Elaborar Projetos de Pesquisa. 4. ed. São Paulo: Atlas, 2002.

GODOY, A. S. Introdução à pesquisa qualitativa e suas possibilidades. Revista de Administração de Empresas, 35(2), 57-63, 1995.

GOMEZ, G. R.; FLORES, J.; JIMÈNEZ, E. Metodologia de la Investigacion Cualitativa, Malaga: Ediciones Aljibe, pp. 378, 1996.

GUBA, E; LINCOLN, Y. Competing paradigms in qualitative research In DENZIN, N.; LINCOLN, Y (Ed) (1994) Handbook of Qualitative Research, Thousand Oaks, CA: SAGE Publications, pp. 105-117, 1994.

INSTITUTO DE PESQUISA ECONÔMICA APLICADA. Políticas sociais acompanhamento e análise. Boletim Educação, n 6, fev. 2003. 
LAKATOS, E. M.; MARCONI, M. A.: Fundamentos de Metodologia Científica. 5. ed. São Paulo: Ed. Atlas, 2003.

LÜDKE, M.; ANDRÉ, M. E. D. A. Pesquisa em educação: abordagens qualitativas. São Paulo: EPU, 1986. 99p.

MERRIAM, S. Qualitative Research and Case Studies Applications in Edu-cation: Revised and Expanded from Case Study Research in Education, San Francisco: Jossey-Bass Publishers, 1998.

MICHELOTTO, R. M.; COELHO, R. H.; ZAINKO, M. A. S. A política de expansão da educação superior e a proposta de reforma universitária do governo Lula. Educar, Curitiba, n. 28, p. 179-198, 2006. Editora UFPR. Disponível em: http://www.scielo.br/pdf/er/n28/a12n28.pdf. Acesso em: 8 fev. 2014.

MINAYO, M. C. de S. O desafio do conhecimento: pesquisa qualitativa em saúde. 11. ed. São Paulo: Abrasco, 2007.

MINAYO, M. C. S. (org.). Pesquisa social: teoria, método e criatividade. 29. ed. Petrópolis, RJ: Vozes, 2010.

NOGUEIRA, P. S. REUNI - um programa de expansão das universidades federais: o caso da UFMT / Patrícia Simone Nogueira. - 2012, 178 f. (Dissertação de Mestrado).

PONTE, J. P. Estudos de caso em educação matemática. Bolema, 25, 105-132, 2006.

ROMANELLI, O. O. História da Educação no Brasil (1930/1973). 28ª ed. Petrópolis: Vozes, 2003. 259.

SAMPAIO, H. Ensino Superior no Brasil - o setor privado. São Paulo, Hucitec, 2000.

SANTOS, A. P.; CERQUEIRA, E. A. ENSINO SUPERIOR: trajetória histórica e políticas recentes. IX Colóquio Internacional sobre Gestão Universitária na América do Sul. Texto on line, s/d. 2009. Disponível em https://pt.scribd.com/document/183811076/Ensino-Superior-Trajetoria-Historica-ePoliticas-Recentes. Acesso em: 10 maio. 2015.

SCHWARTZMAN, S. Os Desafios da Educação no Brasil. In: SCHWARTZMAN, S.; BROCK, C. (Orgs.). Os Desafios da Educação no Brasil. Rio de Janeiro: Nova Fronteira, 2005.

SOARES, M. S. A. (Org.). A Educação Superior no Brasil. Brasília: Coordenação de Aperfeiçoamento de Pessoal de Nível Superior, 2002. 304 p.

SOUZA, P. R. A revolução gerenciada, a educação no Brasil, 1995-2002. São Paulo: Prentice Hall, 2005. 
STELLA, R.C.R.; CAMPOS, J.J. Histórico da construção das diretrizes curriculares nacionais na graduação em medicina no Brasil. Cadernos ABEM. Volume 2, p: 7377, junho 2006.

STELLA, R.C.R. A prática médica no contexto das Diretrizes Curriculares Nacionais para o Curso de Medicina. São Paulo, SP. 2007.14p

TRIVIÑOS, A.N.S. Introdução à pesquisa em ciências sociais: a pesquisa qualitativa em educação. São Paulo: Atlas, 1987.

UNIVERSIDADE FEDERAL DE SÃO PAULO. Ata da reunião ordinária do Conselho Universitário realizada no dia 29 de outubro de 2003. Disponível em: http://unifesp.br/images/docs/atas/29-10-03.pdf. Acesso em: 9 jan. 2017.

UNIVERSIDADE FEDERAL DE SÃO PAULO, Relatório de Gestão de 2003, de novembro de 2003.

UNIVERSIDADE FEDERAL DE SÃO PAULO. Ata da reunião ordinária do Conselho Universitário da Universidade Federal de São Paulo, de 11 de fevereiro de 2004. Disponível em: http://www.unifesp.br/images/docs/atas/11-02-04.pdf. Acesso em: 9 jan. 2017.

UNIVERSIDADE FEDERAL DE SÃO PAULO. Ata da reunião ordinária do Conselho Universitário da Universidade Federal de São Paulo, de 3 de março de 2004. Disponível em: http://www.unifesp.br/images/docs/atas/03-03-04.pdf. Acesso em: 10 jan. 2017.

UNIVERSIDADE FEDERAL DE SÃO PAULO, Ata da reunião ordinária do Conselho Universitário da Universidade Federal de São Paulo, de 10 de março de 2004.

Disponível em: http://www.unifesp.br/images/docs/atas/10-03-04.pdf. Acesso em: 10 jan. 2017.

UNIVERSIDADE FEDERAL DE SÃO PAULO. Ata da reunião ordinária do Conselho Universitário da Universidade Federal de São Paulo, de 14 de abril de 2004. Disponível em: http://www.unifesp.br/images/docs/atas/14-04-04.pdf. Acesso em: 15 jan. 2017

UNIVERSIDADE FEDERAL DE SÃO PAULO. Resolução do Conselho Universitário no 23/2004, de 14 de abril de 2004. Disponível em:

http://www.unifesp.br/images/docs/consu/resolucoes/resolucao23.pdf. Acesso em: 15 maio. 2017.

UNIVERSIDADE FEDERAL DE SÃO PAULO, Ata da reunião ordinária do Conselho Universitário da Universidade Federal de São Paulo, de 9 de junho de 2004.

Disponível em: http://www.unifesp.br/images/docs/atas/09-06-04.pdf. Acesso em: 16 jan. 2017. 
UNIVERSIDADE FEDERAL DE SÃO PAULO, Ata da reunião ordinária do Conselho Universitário da Universidade Federal de São Paulo, de 19 de agosto de 2004.

Disponível em: http://www.unifesp.br/images/docs/atas/19-08-04.pdf. Acesso em: 9 fev. 2017.

UNIVERSIDADE FEDERAL DE SÃO PAULO, Ata da reunião ordinária do Conselho Universitário da Universidade Federal de São Paulo, de 15 de setembro de 2004. Disponível em: http://www.unifesp.br/images/docs/atas/15-09-04.pdf. Acesso em: 9 fev. 2017.

UNIVERSIDADE FEDERAL DE SÃO PAULO, Ata da reunião ordinária do Conselho Universitário da Universidade Federal de São Paulo, de 13 de outubro de 2004.

Disponível em: http://www.unifesp.br/images/docs/atas/13-10-04.pdf. Acesso em: 9 fev. 2017.

UNIVERSIDADE FEDERAL DE SÃO PAULO, Ata da reunião ordinária do Conselho Universitário da Universidade Federal de São Paulo, de 10 de novembro de 2004. Disponível em: http://www.unifesp.br/images/docs/atas/10-11-04.pdf. Acesso: fev. 9 2017.

UNIVERSIDADE FEDERAL DE SÃO PAULO, Ata da reunião ordinária do Conselho Universitário da Universidade Federal de São Paulo, de 9 de março de 2005.

Disponível em: http://www.unifesp.br/images/docs/atas/09-03-05.pdf. Acesso em: 12 fev. 2011.

UNIVERSIDADE FEDERAL DE SÃO PAULO, Ata da reunião ordinária do Conselho Universitário da Universidade Federal de São Paulo, de 13 de julho de 2005.

Disponível em: http://www.unifesp.br/images/docs/atas/13-07-05.pdf. Acesso em: 7 mar. 2017.

UNIVERSIDADE FEDERAL DE SÃO PAULO, Ata da reunião ordinária do Conselho Universitário da Universidade Federal de São Paulo, realizada aos 10 de agosto de 2005. Disponível em: http://www.unifesp.br/images/docs/atas/10-08-05.pdf. Acesso em: 7 mar. 2017.

UNIVERSIDADE FEDERAL DE SÃO PAULO, Ata da reunião ordinária do Conselho Universitário da Universidade Federal de São Paulo, de 5 de outubro de 2005.

Disponível em: http://www.unifesp.br/images/docs/atas/05-10-05.pdf. Acesso em: 14 mar. 2017.

UNIVERSIDADE FEDERAL DE SÃO PAULO, Ata da reunião ordinária do Conselho Universitário da Universidade Federal de São Paulo de 14 de dezembro de 2005.

Disponível em: http://www.unifesp.br/images/docs/atas/14-12-05.pdf. Acesso em: 14 mar. 2017. 
UNIVERSIDADE FEDERAL DE SÃO PAULO, Resolução no 32 , de 15 de dezembro de 2005. Disponível em:

http://www.unifesp.br/images/docs/consu/resolucoes/resolucao32.pdf. Acesso em: 17 abr. 2017.

UNIVERSIDADE FEDERAL DE SÃO PAULO. Plano de Desenvolvimento Institucional (PDI) 2005-2010. São Paulo, SP, dezembro de 2005.

UNIVERSIDADE FEDERAL DE SÃO PAULO, Ata da reunião ordinária do Conselho Universitário da Universidade Federal de São Paulo, de 8 de março de 2006.

Disponível em: http://www.unifesp.br/images/docs/atas/08-03-06.pdf. Acesso em: 17 abr. 2017.

UNIVERSIDADE FEDERAL DE SÃO PAULO, Ata da reunião ordinária do Conselho Universitário da Universidade Federal de São Paulo, de 12 de abril de 2006.

Disponível em: http://www.unifesp.br/images/docs/atas/12-04-06.pdf. Acesso em: 18 abr. 2017.

UNIVERSIDADE FEDERAL DE SÃO PAULO, Ata da reunião ordinária do Conselho Universitário da Universidade Federal de São Paulo, de 10 de maio de 2006.

Disponível em: http://www.unifesp.br/images/docs/atas/10-05-06.pdf. Acesso em: 18 abr. 2017.

UNIVERSIDADE FEDERAL DE SÃO PAULO, Atas da reunião ordinária do Conselho Universitário da Universidade Federal de São Paulo, de 22 de junho de 2006.

Disponível em: http://www.unifesp.br/images/docs/atas/22-06-06.pdf. Acesso em: 19 abr. 2017.

UNIVERSIDADE FEDERAL DE SÃO PAULO, Ata da reunião ordinária do Conselho Universitário da Universidade Federal de São Paulo, de 12 de julho de 2006.

Disponível em: http://www.unifesp.br/images/docs/atas/12-07-06.pdf. Acesso em: 19 abr. 2017.

UNIVERSIDADE FEDERAL DE SÃO PAULO, Ata da reunião ordinária do Conselho Universitário da Universidade Federal de São Paulo, de 13 de setembro de 2006.

Disponível em: http://www.unifesp.br/images/docs/atas/13-09-06.pdf. Acesso em: 22 abr. 2017.

UNIVERSIDADE FEDERAL DE SÃO PAULO, Ata da reunião ordinária do Conselho Universitário da Universidade Federal de São Paulo, de 11 de outubro de 2006.

Disponível em: http://www.unifesp.br/images/docs/atas/11-10-06.pdf. Acesso em: 22 abr. 2017. 
UNIVERSIDADE FEDERAL DE SÃO PAULO, Ata da reunião ordinária do Conselho Universitário da Universidade Federal de São Paulo, de 8 de novembro de 2006.

Disponível em: http://www.unifesp.br/images/docs/atas/08-11-06.pdf. Acesso em: 23 abr. 2017.

UNIVERSIDADE FEDERAL DE SÃO PAULO, Ata da reunião ordinária do Conselho Universitário da Universidade Federal de São Paulo, de 13 de dezembro de 2006. Disponível em: http://www.unifesp.br/images/docs/atas/13-12-06.pdf. Acesso em: 16 maio. 2017.

UNIVERSIDADE FEDERAL DE SÃO PAULO, Ata da reunião ordinária do Conselho Universitário da Universidade Federal de São Paulo, de 14 de março de 2007.

Disponível em: http://www.unifesp.br/images/docs/atas/14-03-07.pdf. Acesso em: 16 maio. 2017.

UNIVERSIDADE FEDERAL DE SÃO PAULO, Ata da reunião ordinária do Conselho Universitário da Universidade Federal de São Paulo, de 13 de junho de 2007. Disponível em: http://www.unifesp.br/images/docs/atas/13-06-07.pdf. Acesso em: 16 maio. 2017.

UNIVERSIDADE FEDERAL DE SÃO PAULO, Edital de retificação do Concurso Vestibular UNIFESP 2008, 4 de setembro de 2007. Disponível em:

http://www.unifesp.br/reitoria/vestibular/arquivo/category/40-manuais-e-editais. Acesso em: 3 jul. 2017.

UNIVERSIDADE FEDERAL DE SÃO PAULO, Ata da reunião ordinária do Conselho Universitário da Universidade Federal de São Paulo, de 12 de setembro de 2007. Disponível em: http://www.unifesp.br/images/docs/atas/12-09-07.pdf. Acesso em: 3 17 maio. 2017.

UNIVERSIDADE FEDERAL DE SÃO PAULO, Ata da reunião extraordinária do Conselho Universitário da Universidade Federal de São Paulo, de 17 de outubro de 2007. Disponível em: http://www.unifesp.br/images/docs/atas/17-10-07.pdf. Acesso em: 17 maio. 2017.

UNIVERSIDADE FEDERAL DE SÃO PAULO, Ata da reunião extraordinária do Conselho Universitário da Universidade Federal de São Paulo, de 21 de novembro de 2007. Disponível em: http://www.unifesp.br/images/docs/atas/21-11-07.pdf. Acesso em: 20 maio. 2017.

UNIVERSIDADE FEDERAL DE SÃO PAULO, Ata da reunião ordinária do Conselho Universitário da Universidade Federal de São Paulo, de 13 de fevereiro de 2008.

Disponível em: http://www.unifesp.br/images/docs/atas/13-02-08.pdf. Acesso em: 20 maio. 2017. 
UNIVERSIDADE FEDERAL DE SÃO PAULO, Ata da reunião ordinária do Conselho Universitário da Universidade Federal de São Paulo, de 12 de março de 2008.

Disponível em: http://www.unifesp.br/images/docs/atas/12-03-08.pdf. Acesso em: 23 maio. 2017.

UNIFESP, Programa de Apoio a Planos de Reestruturação e Expansão das Universidades Federais (REUNI) - Proposta de adesão.

UNIVERSIDADE FEDERAL DE SÃO PAULO, Edital Concurso Vestibular UNIFESP 2009, 3 de setembro de 2008. Disponível em:

http://www.unifesp.br/reitoria/vestibular/arquivo/category/35-manuais-e-editais.

Acesso em: 2 jul. 2017.

UNIVERSIDADE FEDERAL DE SÃO PAULO, Ata da reunião ordinária do Conselho Universitário da Universidade Federal de São Paulo, de 13 de maio de 2009.

Disponível em: http://www.unifesp.br/images/docs/atas/13-05-09.pdf. Acesso em: 2 jun. 2017.

UNIVERSIDADE FEDERAL DE SÃO PAULO, Ata da reunião ordinária do Conselho Universitário da Universidade Federal de São Paulo, de 10 de junho de 2009.

Disponível em: http://www.unifesp.br/images/docs/atas/10-06-09.pdf. Acesso em: 3 jun. 2017.

UNIVERSIDADE FEDERAL DE SÃO PAULO, Edital Concurso Vestibular UNIFESP 2010, 7 de julho de 2009. Disponível em:

http://www.unifesp.br/reitoria/vestibular/arquivo/category/31-manuais-e-editais.

Acesso em: 4 jul. 2017.

UNIVERSIDADE FEDERAL DE SÃO PAULO, Balanço do primeiro ano do REUNI da UNIFESP, de 31 de outubro de 2009

UNIVERSIDADE FEDERAL DE SÃO PAULO, Ata da reunião extraordinária do Conselho Universitário da Universidade Federal de São Paulo, de 4 de novembro de 2009. Disponível em: http://www.unifesp.br/images/docs/atas/04-11-09.pdf. Acesso em: 3 jun. 2017.

UNIVERSIDADE FEDERAL DE SÃO PAULO, Ata da reunião ordinária do Conselho Universitário da Universidade Federal de São Paulo, de 9 de junho de 2010.

Disponível em: http://www.unifesp.br/images/docs/atas/09-06-10.pdf. Acesso em: 3 jun. 2017.

UNIVERSIDADE FEDERAL DE SÃO PAULO, Ata da reunião ordinária do Conselho Universitário da Universidade Federal de São Paulo, de 11 de agosto de 2010.

Disponível em: http://www.unifesp.br/images/docs/atas/11-08-10.pdf. Acesso em: 4 jun. 2017. 
UNIVERSIDADE FEDERAL DE SÃO PAULO, Edital Concurso Vestibular UNIFESP 2011, 24 de agosto de 2010. Disponível em:

http://www.unifesp.br/reitoria/vestibular/arquivo/category/25-manuais-e-editais. Acesso em: 4 jul. 2017.

UNIVERSIDADE FEDERAL DE SÃO PAULO, Ata da reunião ordinária do Conselho Universitário da Universidade Federal de São Paulo, de 8 de dezembro de 2010. Disponível em: http://www.unifesp.br/images/docs/atas/08-12-10.pdf. Acesso em: 10 jun. 2017.

UNIVERSIDADE FEDERAL DE SÃO PAULO, Ata da reunião ordinária do Conselho Universitário da Universidade Federal de São Paulo de 8 de junho de 2011.

Disponível em: http://www.unifesp.br/images/docs/atas/08-06-11.pdf. Acesso em: 10 jun. 2017.

UNIVERSIDADE FEDERAL DE SÃO PAULO, Edital Concurso Vestibular UNIFESP 2012, 5 de setembro de 2012. Disponível em:

http://www.unifesp.br/reitoria/vestibular/arquivo/category/20-manuais-e-editais.

Acesso em: 4 jul. 2017.

UNIVERSIDADE FEDERAL DE SÃO PAULO, Ata da reunião ordinária do Conselho Universitário da Universidade Federal de São Paulo, de 14 de setembro de 2011.

Disponível em: http://www.unifesp.br/images/docs/atas/14-09-11.pdf. Acesso em: 11 jun. 2017.

UNIVERSIDADE FEDERAL DE SÃO PAULO, Ata da reunião ordinária do Conselho Universitário da Universidade Federal de São Paulo de 9 de novembro de 2011. Disponível em: http://www.unifesp.br/images/docs/atas/09-11-11.pdf. Acesso em: 11 jun. 2017.

UNIVERSIDADE FEDERAL DE SÃO PAULO, Ata da reunião ordinária do Conselho Universitário da Universidade Federal de São Paulo de 14 de dezembro de 2011. Disponível em: http://www.unifesp.br/images/docs/atas/14-12-11.pdf. Acesso em: 11 jun. 2017.

UNIVERSIDADE FEDERAL DE SÃO PAULO. EntreTeses Revista UNIFESP, $n^{\circ} 1$, ano 1. Novembro 2013.

VIEIRA, S. L. Reformas Educativas no Brasil: uma aproximação histórica. Fortaleza, Brasil. Abril/2009. Disponível em: <http://pt.slideshare.net/lasminCosta/reformaseducativas-no-brasil-uma-aproximao-histrica>. Acesso em: 22 mar. 2015.

YIN, R. Estudo de caso: planejamento e métodos. $4^{\text {a }}$ ed. Porto Alegre: Bookman; 2010. 
XAVIER, M. E.; RIBEIRO, M. L.; NORONHA, O. M. História da educação: a escola no Brasil. São Paulo: FTD, 1994. 
UNIFESP

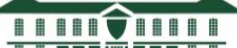

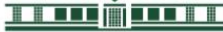
ERAL DE STO P
Universidade Federal de São Paulo - UNIFESP Centro de Desenvolvimento do Ensino Superior em Saúde

Relatório Técnico de Pesquisa

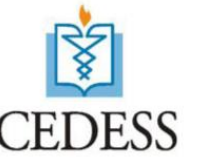

MARIA BERNADETE DE NORONHA DANTAS ROSSETTO NILDO ALVES BATISTA

PAULETE GOLDENBERG

\section{ANÁLISE DA EXPANSÃO DA GRADUAÇÃO NA UNIVERSIDADE FEDERAL DE SÃO PAULO NO PERÍODO DE 2003 A 2012}

SÃO PAULO 
UNIFESP

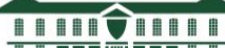
IIIIII圆 IIIIIIII ESERO P
Universidade Federal de São Paulo - UNIFESP Centro de Desenvolvimento do Ensino Superior em Saúde

Relatório Técnico de Pesquisa

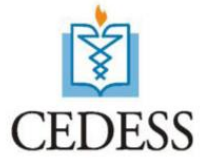

MARIA BERNADETE DE NORONHA DANTAS ROSSETTO

\title{
ANÁLISE DA EXPANSÃO DA GRADUAÇÃO NA UNIVERSIDADE FEDERAL DE SÃO PAULO NO PERÍODO DE 2003 A 2012
}

\author{
Relatório Técnico de Pesquisa, apresentado \\ como requisito parcial à obtenção do título de \\ Mestre em Ciências do Programa de Mestrado \\ Ensino em Ciências da Saúde, modalidade \\ Mestrado profissional, pela Universidade Federal \\ de São Paulo. \\ Orientador: Prof. Dr. Nildo Alves Batista \\ Co-orientadora: Profa. Dra. Paulete Goldenberg
}

Aprovado pela Banca Examinadora em 22/09/2017 


\section{SUMÁRIO}

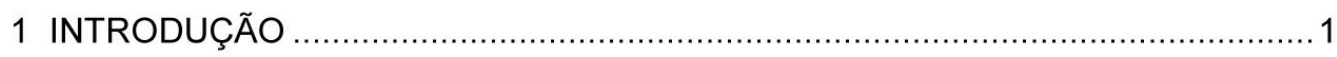

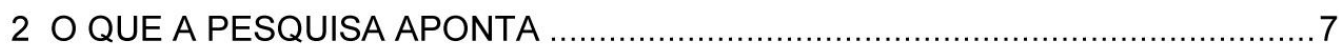

3 CONSIDERAÇÕES/RECOMENDAÇÕES AOS GESTORES DA UNIVERSIDADE 15

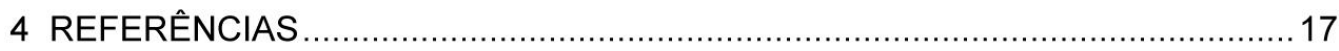




\section{INTRODUÇÃO}

Este relatório destaca aspectos fundamentais da pesquisa "A Expansão da Graduação na Universidade Federal de São Paulo no período de 2003 a 2012" realizada como requisito parcial para a obtenção do título de Mestre Profissional pelo Programa de Pós-Graduação Ensino em Ciências da Saúde, oferecido pelo Centro de Desenvolvimento do Ensino Superior em Saúde (CEDESS) da UNIFESP.

Nessa modalidade de pós-graduação busca-se capacitar/qualificar o mestrando para o desenvolvimento de uma pesquisa cujo objeto emerja da sua própria prática profissional, tornando-o mais crítico, criativo e transformador da mesma. Neste sentido, a produção técnica é também requisito final, entendendo-se que os resultados da pesquisa ampliam o conhecimento sobre a realidade investigada, aumentando a possibilidade de elaboração de um produto de intervenção. Entende-se a relevância desse produto no sentido de levar à reflexão e à possíveis ações para o aprimoramento do cotidiano pesquisado.

A pesquisa realizada abordou os aspectos da expansão das Instituições Federais de Ensino Superior (IFES) no Brasil e que foi um processo importante para o ensino superior no país, principalmente nas duas últimas décadas, e contou com o Programa de Expansão das Universidades Brasileiras e com o Programa de Apoio a Planos de Reestruturação e Expansão das Universidades Federais (REUNI).

A Universidade Federal de São Paulo (UNIFESP) acompanhou o processo nacional, com especificidades e grande transformação. Para conhecer e mapear o processo de expansão do ensino superior nas IFES e na UNIFESP levantou-se as questões de pesquisa:

1. Como se deu a expansão das IFES no período de 2003 a $2007 ?$

2. O que significou o REUNI para a expansão das IFES?

3. Como estava a UNIFESP na fase inicial desta expansão nacional do Ensino Superior público?

4. Como a UNIFESP aderiu a esse movimento de expansão no período de 2003 a $2012 ?$ 
5. O que significou essa expansão em relação aos indicadores quantitativos da graduação na instituição?

O período delineado para a investigação foi de 2003 a 2012: 2003 por ter sido o ano no qual teve início as discussões da expansão das IFES em nível nacional e 2012, por ter sido o último ano de vigência do Programa de Apoio a Planos de Reestruturação e Expansão das Universidades Federais (REUNI).

Objetivou-se analisar o processo de expansão da graduação na instituição, no período compreendido entre 2003 e 2012. Especificamente procurou-se caracterizar a expansão nacional das Instituições Federais de Ensino Superior no período de 2003 a 2012, conhecer o significado do Programa de Apoio a Planos de Restruturação e Expansão das Universidades Federais para a expansão das Instituições Federais de Ensino Superior, descrever a expansão da Universidade Federal de São Paulo desde sua adesão ao processo nacional até o ano de 2012 e analisar a expansão da Universidade Federal de São Paulo em relação aos indicadores quantitativos da graduação.

Neste estudo realizou-se uma pesquisa de caráter descritivo analítico com análise documental, tipo estudo de caso.

Os dados foram produzidos por meio de uma pesquisa documental que, de acordo com Gil (2002, p.45), "vale-se de materiais que não recebem ainda um tratamento analítico ou que ainda podem ser reelaborados de acordo com os objetos da pesquisa". Para Lüdke e André (1986), a pesquisa documental é uma importante técnica utilizada para complementar informações de pesquisa, obtidas por meio de outros instrumentos na abordagem qualitativa ou então, para indicar novas dimensões do tema.

Partiu-se do pressuposto que a realização de um estudo de documentos deve levar em consideração o ponto de vista de quem os produziu, o que requer cuidado, por parte do pesquisador, para não comprometer a validade do seu estudo. Os documentos incluídos na pesquisa foram: publicações oficiais (12 documentos), legislações (4), atas das reuniões do Conselho Universitário da UNIFESP no período de 2003 a 2012 (141), publicações de gestão da UNIFESP (9) e editais de concursos vestibulares da UNIFESP (5). 
Nos meses de fevereiro e março de 2016, realizou-se uma busca livre na internet de dissertações e teses publicadas desde 2003 que abordassem o tema "expansão do ensino superior no Brasil". A leitura das 12 dissertações e 2 teses encontradas permitiu identificar publicações oficiais e legislação referentes ao tema.

As publicações oficiais utilizadas nesta pesquisa foram:

1 ASSOCIAÇÃO NACIONAL DOS DIRIGENTES DAS INSTITUIÇÕES FEDERAIS DE ENSINO SUPERIOR. Consolidação dos dados acadêmicos, orçamentários e de pessoal referentes aos acordos de metas do Programa de Apoio a Planos de Reestruturação das Universidades - REUNI. [Relatório de Consultoria de Maria leda Costa Diniz]. Brasília (DF). Outubro de 2009.

2 ASSOCIAÇÃO NACIONAL DOS DIRIGENTES DAS INSTITUIÇÕES FEDERAIS DE ENSINO SUPERIOR. Reforma Universitária: proposta da Andifes para a reestruturação da Educação Superior no Brasil. Maio de 2004.

3 ASSOCIAÇÃO NACIONAL DOS DIRIGENTES DAS INSTITUIÇÕES FEDERAIS DE ENSINO SUPERIOR. Relatório de Acompanhamento do Programa de Apoio a Planos de Reestruturação e Expansão das Universidades Federais - REUNI. Brasília (DF): ANDIFES, jan. 2010.

$4 \quad$ BRASIL. Grupo de trabalho interministerial. Bases para o enfrentamento da crise emergencial das universidades federais e roteiro para a reforma universitária brasileira. Brasília: [s.n.], 15 de dezembro de 2003.

5 BRASIL. Ministério da Educação. A democratização e expansão da educação superior no país 2003 - 2014. Balanço das principais políticas e programas. 2015[?].

6 BRASIL. Ministério da Educação. Análise sobre a Expansão das Universidades Federais 2003 a 2012. Brasília, 2012b.

7 BRASIL. Ministério da Educação. Expansão das Universidades Federais, o sonho se torna realidade! Coordenação geral: Maria leda Costa Diniz. Brasília. 2006a. 
8 BRASIL. Ministério da Educação. O Plano de Desenvolvimento da Educação. Razões, Princípios e Programas. Brasília, 24 de abril de 2007a.

9 BRASIL. Ministério da Educação. Programa de Apoio a Planos de Reestruturação e Expansão das Universidades Federais. Reuni 2008 Relatório de Primeiro Ano. Brasília (DF), 30 de outubro de 2009.

10 BRASIL. Ministério da Educação. Reforma da Educação Superior. Documento II. Reafirmando princípios e consolidando diretrizes da Reforma da Educação Superior. Brasília, 2 de agosto de 2004a.

11 BRASIL. Ministério da Educação. Relatório da Comissão Constituída pela Portaria $n^{\circ} 126 / 2012$, sobre a Análise sobre a Expansão das Universidades Federais 2003 a 2012. Brasília, 2012a.

12 UNIVERSIDADE FEDERAL DE SÃO PAULO. Programa de Apoio a Planos de Reestruturação e Expansão das Universidades Federais (REUNI) - Proposta de adesão.

A legislação utilizada foi:

1. BRASIL. Lei $n^{\circ} 10.172$, de 9 de janeiro de 2001. Aprova o Plano Nacional de Educação e dá outras providências. Diário Oficial da União, Brasília, DF, 10 jan. 2001a. PNE - 2001-2010.

2. BRASIL. Ministério da Educação. Projeto de Lei $n^{0} 7.200$, de 12 junho de 2006b. Estabelece normas gerais da educação superior, regula a educação superior no sistema federal de ensino.

3. BRASIL. Decreto $n^{\circ} 6.096$, de 24 de abril de 2007b. Institui o Programa de Apoio a Planos de Reestruturação e Expansão das Universidades Federais - REUNI. Presidência da República. Brasília, DF: Diário Oficial da União de 25.04.2007.

4. BRASIL. Portaria ${ }^{\circ} 552$ SESu/MEC, de 25 de junho de 2007c: Diretrizes Gerais do Programa de Apoio a Planos de Reestruturação e Expansão das Universidades Federais - REUNI. GRUPO ASSESSOR. Brasília, DF: MEC; Secretaria da Educação Superior, 2007. 
Nos meses de janeiro a junho de 2017 , acessou-se o portal da UNIFESP na internet em busca de publicações e documentos da instituição relacionadas ao tema. Encontrou-se atas, publicações de gestão e editais de vestibular. Dentre as atas das reuniões do Conselho Universitário da UNIFESP ocorridas entre 2003 e 2012, selecionou-se 52 que continham registros de informes e discussões sobre a expansão e o REUNI.

Das publicações de gestão da UNIFESP, 8 integraram o conjunto de documentos analisados. São eles:

1. UNIVERSIDADE FEDERAL DE SÃO PAULO. Relatório de Gestão de 2003, de novembro de 2003;

2. UNIVERSIDADE FEDERAL DE SÃO PAULO. Relatório de Gestão de 2004, de novembro de 2004.

3. UNIVERSIDADE FEDERAL DE SÃO PAULO. Relatório de Gestão de 2005, de novembro de 2005.

4. UNIVERSIDADE FEDERAL DE SÃO PAULO. Relatório de Gestão de 2006, de novembro de 2006.

5. UNIVERSIDADE FEDERAL DE SÃO PAULO. Relatório de Gestão de 2007, de novembro de 2007.

6. UNIVERSIDADE FEDERAL DE SÃO PAULO. Programa de Apoio a Planos de Reestruturação e Expansão das Universidades Federais (REUNI) - Proposta de adesão;

7. UNIVERSIDADE FEDERAL DE SÃO PAULO. Balanço do Primeiro ano do REUNI da UNIFESP, de 31 de outubro de 2009.

8. UNIVERSIDADE FEDERAL DE SÃO PAULO. Plano de Desenvolvimento Institucional (PDI) 2005-2010. São Paulo, SP, dezembro de 2009. 
Os editais dos concursos vestibulares da UNIFESP do período de 2008 a 2012 também foram utilizados:

1. UNIVERSIDADE FEDERAL DE SÃO PAULO, Edital de retificação do Concurso Vestibular. UNIFESP 2008, 4 de setembro de 2007.

2. UNIVERSIDADE FEDERAL DE SÃO PAULO, Edital Concurso Vestibular UNIFESP 2009, 3 de setembro de 2008.

3. UNIVERSIDADE FEDERAL DE SÃO PAULO, Edital Concurso Vestibular UNIFESP 2010, 7 de julho de 2009.

4. UNIVERSIDADE FEDERAL DE SÃO PAULO, Edital Concurso Vestibular UNIFESP 2011, 24 de agosto de 2010.

5. UNIVERSIDADE FEDERAL DE SÃO PAULO, Edital Concurso Vestibular UNIFESP 2012, 5 de setembro de 2012.

Realizada a seleção dos documentos, procedeu-se à análise dos dados, com o intuito de produzir ou reelaborar conhecimentos e criar novas formas de compreender a expansão da graduação na UNIFESP. Os dados coletados foram analisados por meio da técnica de análise de conteúdo, modalidade temática, segundo Franco (2012).

Este relatório técnico tem o objetivo de apresentar os resultados aos gestores da UNIFESP com o objetivo de apresentar, de maneira sistematizada, o que ocorreu na instituição. 


\section{QUE A PESQUISA APONTA}

Os documentos evidenciaram que o panorama geral da educação superior, na primeira fase da expansão (2003 a 2007), era de crise no ensino superior do Brasil e apontava para o reconhecimento do papel estratégico da educação superior pública e para a necessidade de uma reforma da educação superior.

No período entre 2008 e 2012, os documentos reforçaram o panorama já delineado, a necessidade de articulação dos eixos da expansão e a definição mais precisa das metas. Observou-se um crescimento global das IFES no processo de expansão como um todo (primeira fase e programa REUNI) de $106 \%$ no número de campi (de 148 para 305) e de 125\% no número de cursos (de 2078 para 4.672).

A análise dos documentos relativos à primeira fase da expansão aponta para a constatação de crise no ensino superior brasileiro, reconhecimento do papel estratégico da educação superior pública e para a necessidade de uma Reforma da Educação Superior.

Quantitativamente, os dados coletados demonstraram que até o ano de 2002, o Brasil contava com 45 Universidades Federais e 148 campi/unidades, de acordo com o documento "Análise sobre a Expansão das Universidades Federais 2003 a 2012" (BRASIL. MEC, 2012).

No período de 2003 a 2007, foram criadas dez universidades federais em regiões, prioritariamente, não metropolitanas, dentre as quais, duas $(20 \%)$ na região nordeste, quatro $(40 \%)$ na região sudeste, três $(30 \%)$ na região sul e uma $(10 \%)$ na região centro-oeste.

Nesse período foram criados 79 novos campi: 31 (39\%) na região nordeste; $16(20 \%)$ na região norte; $13(17 \%)$ na região sudeste; $16(20 \%)$ na região sul e $3(4 \%)$ na região centro-oeste.

Assim, na primeira fase da expansão ocorreu um crescimento de 30.691 vagas ofertadas para alunos ingressantes nos cursos de graduação nas universidades federais brasileiras (de 109.184 vagas em 2003 para 139.875 em 2007). O crescimento do número de cursos foi de 582 (de 2.078 cursos em 2003 
para 2.660 em 2007). O número de matrículas aumentou em 50.817 (de 527.719 matrículas em 2003 para 578.536 em 2007).

A análise dos documentos referentes ao período de 2008 a 2012, consequentes da implementação dos projetos REUNI na expansão das IFES, possibilitou apreender as seguintes categorias: reforço ao panorama já delineado no período inicial de expansão das IFES, reconhecimento de sinais de esgotamento oriundos da expansão das universidades privadas; (c) Articulação dos eixos da expansão e definição mais precisa das metas; (d) Instituição do PDE, como avanço do PNE, em relação à necessidade de reestruturação de grande alcance do parque universitário federal; (d) Assunção de uma visão sistêmica da educação e da sua relação com a ordenação territorial e o desenvolvimento econômico e social; (e) Reconhecimento da necessidade de inovações curriculares na graduação; (f) Reconhecimento da necessidade de expansão dos cursos noturnos; (g) Reconhecimento da necessidade de uma política nacional de assistência estudantil e Reconhecimento da necessidade de uma política nacional de formação de professores.

Como resultados quantitativos os dados demonstraram que no período compreendido entre 2008 e 2012, foram criadas mais 4 universidades federais, dentre as quais 1 (25\%) na região nordeste, 1 (25\%) na região norte e 2 (50\%) na região sul.

Nesse mesmo período, foram criados mais 78 novos campi: 22 (28\%) na região nordeste, 4 (5\%) na região norte, 19 (24\%) na região sudeste, 28 (36\%) na região sul e $5(7 \%)$ na região centro-oeste.

Com esta etapa ocorreu um crescimento de 80.661 vagas ofertadas para alunos ingressantes nos cursos de graduação das universidades federais (de 150.869 vagas em 2008 para 231.530 em 2011). O número de cursos teve um aumento de 1.850 (de 2.822 cursos em 2008 para 4.672 em 2012). Observou-se ainda um crescimento de 241.834 no número de matrículas na graduação (de 600.772 matrículas em 2008 para 842.606 em 2011).

$\mathrm{Na}$ UNIFESP, a análise documental os dados coletados demonstraram que no período de 2003 a 2007, a instituição aumentou de 1 para 5 campi. Contava com 
273 vagas distribuídas em 5 cursos de graduação em 2004. Em 2005, o número de vagas aumentou em 10\%, devido ao Programa de Ações Afirmativas, passando para 300. Em 2006, com a expansão para o Campus Baixada Santista, a UNIFESP passou a ofertar 490 vagas, o que representou um aumento de $63 \%$. Em 2007, com a expansão para os campi de Diadema, Guarulhos e São José dos Campos, a UNIFESP passou a ofertar 1.150 vagas, conforme demonstra o Gráfico 1. (UNIFESP, Balanço do Primeiro ano do REUNI da UNIFESP, de 31 de outubro de 2009).

Gráfico 1. Crescimento de vagas ofertadas nos cursos na graduação, na UNIFESP

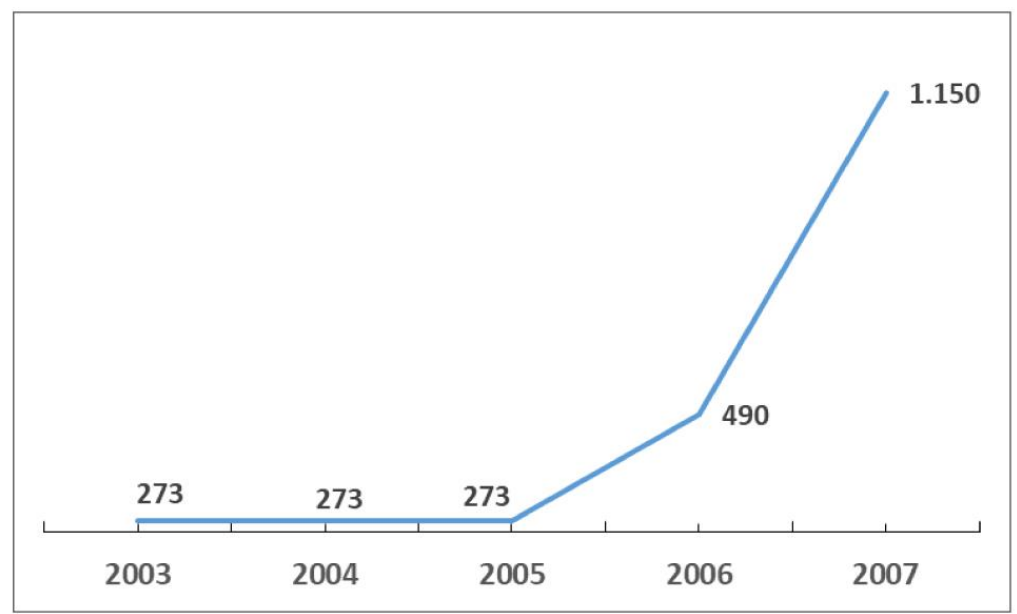

Fonte: Gráfico elaborado pela autora.

Com a expansão inicial para o Campus Baixada Santista, a UNIFESP passou a ter 10 cursos, o que representou um aumento de $63 \%$. Em todo o período, ocorreu um crescimento no número dos cursos de graduação na instituição de $360 \%$ : de 5 cursos em 2003, para 23 em 2007, num total de 18 cursos a mais, demonstrado pelo Gráfico 2. 
Gráfico 2. Crescimento no número de cursos na graduação, na UNIFESP

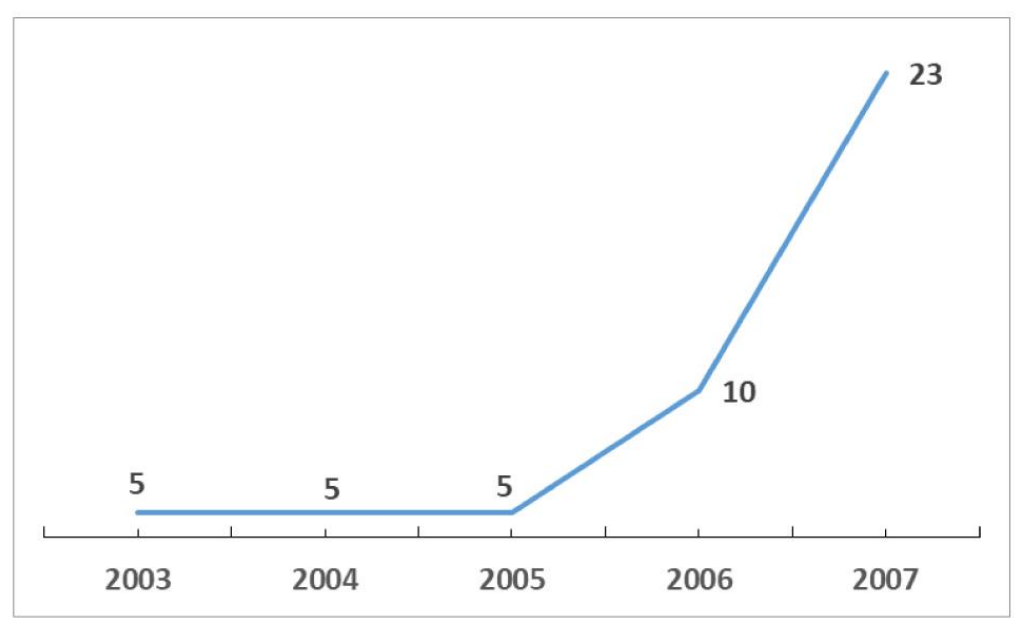

Fonte: Gráfico elaborado pela autora.

O número de novas matrículas nos cursos de graduação teve um crescimento de 1.016, na primeira fase da expansão: de 1.296 matrículas em 2003, para 2.312, em 2007. O Gráfico 3 mostra que os dados apontaram para um crescimento mais significativo de matrículas com o início de novos campi e cursos na UNIFESP: de 2005 para 2006 foram 217 matrículas e de 2006 para 2007, foram 776 .

Gráfico 3. Crescimento de número de matrículas na graduação, na UNIFESP

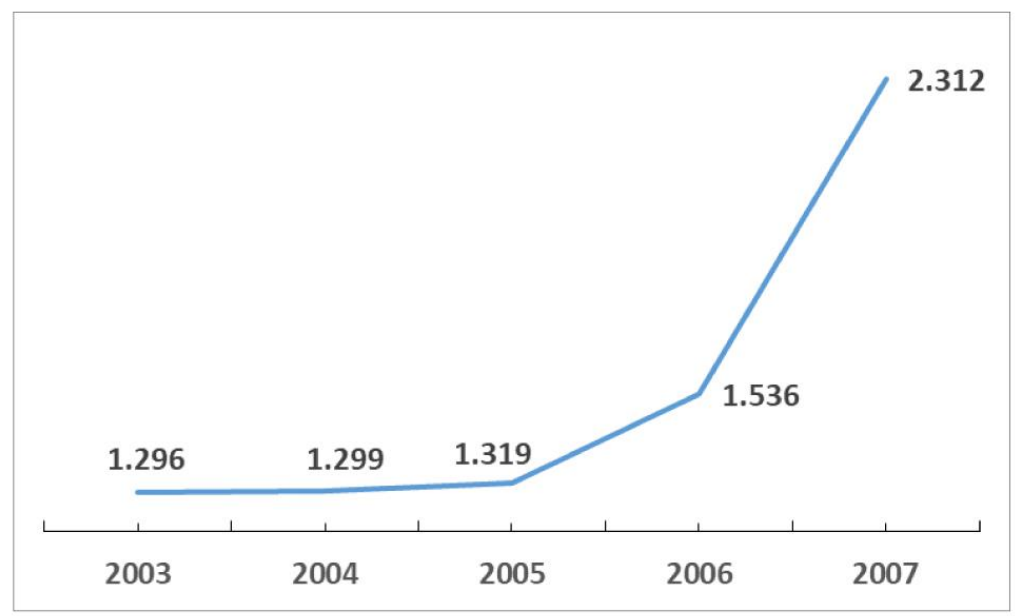

Fonte: Gráfico elaborado pela autora 
No período entre 2008 e 2012, a UNIFESP passou para 54 cursos de graduação, conforme Gráfico 4, com um total de oferta de vagas de 2.869 vagas, apontando um aumento de $150 \%$ neste período.

Gráfico 4. Crescimento do no número de cursos na graduação, na UNIFESP

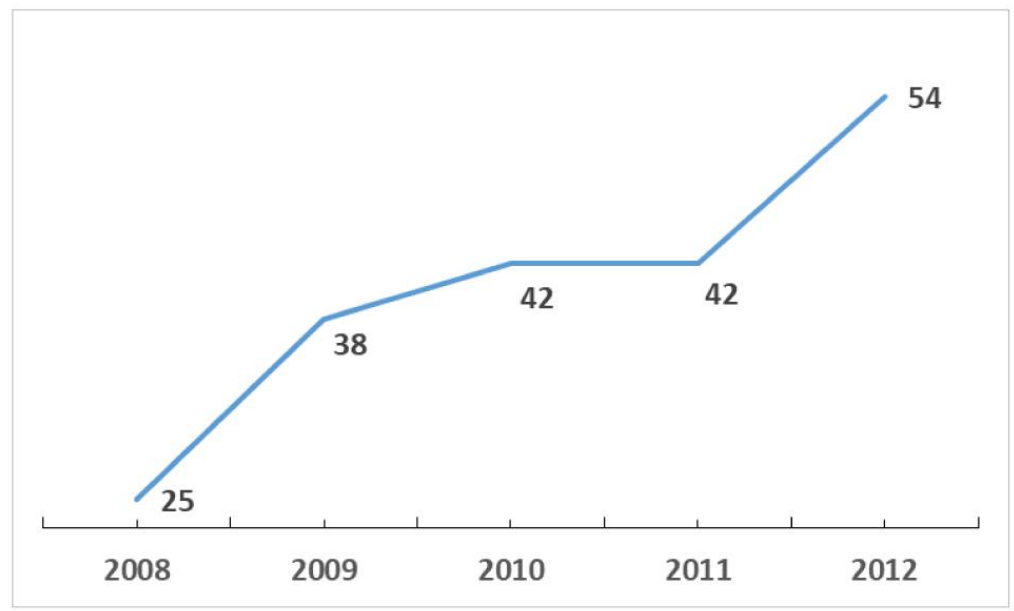

Fonte: Gráfico elaborado pela autora

Importante enfatizar que, além do pactuado no projeto REUNI da instituição, a UNIFESP criou mais um Campus (Osasco), com 4 cursos de graduação e o Bacharelado em Ciência e Tecnologia, no Campus São José dos Campos.

Esta ampliação de vagas no período de 2008 a 2012 foi consequência da criação dos seguintes cursos:

(a) Campus Baixada Santista: curso de Serviço Social (noturno e vespertino) e o curso de Bacharelado Interdisciplinar em Ciências do Mar (noturno e vespertino);

(b) Campus Diadema: curso de Ciências Ambientais (integral), de Farmácia e Bioquímica (noturno), de Química Industrial (noturno), de Licenciatura Plena em Ciências (noturno e vespertino);

(c) Campus de Guarulhos: curso de História da Arte (noturno), de Letras Português (noturno e vespertino), de Letras - Português/Espanhol (noturno e vespertino), de Letras - Português /Francês (noturno e vespertino), de Letras Português/Inglês (noturno e vespertino); 
(d) Campus São José dos Campos: curso de Matemática Computacional (noturno) e de Bacharelado em Ciência e Tecnologia (integral);

(e) Campus São Paulo: curso de Tecnologia Radiológica (matutino) e de Tecnologia em Informática e Saúde (matutino);

(f) Campus de Osasco: curso de Administração (noturno e integral), de Ciências Contábeis (noturno e integral), de Ciências Econômicas (noturno e integral) e de Relações Internacionais (noturno e integral).

Neste período de 2008 a 2012, a evolução de vagas ofertadas para alunos ingressantes nos cursos de graduação foi de 609 entre 2008 e 2009, 386 entre 2009 e 2010, 150 entre 2010 e 2011 e de 201 vagas entre 2011 e 2012 (Gráfico 5).

Gráfico 5. Crescimento do número de vagas ofertadas nos cursos de graduação, na UNIFESP

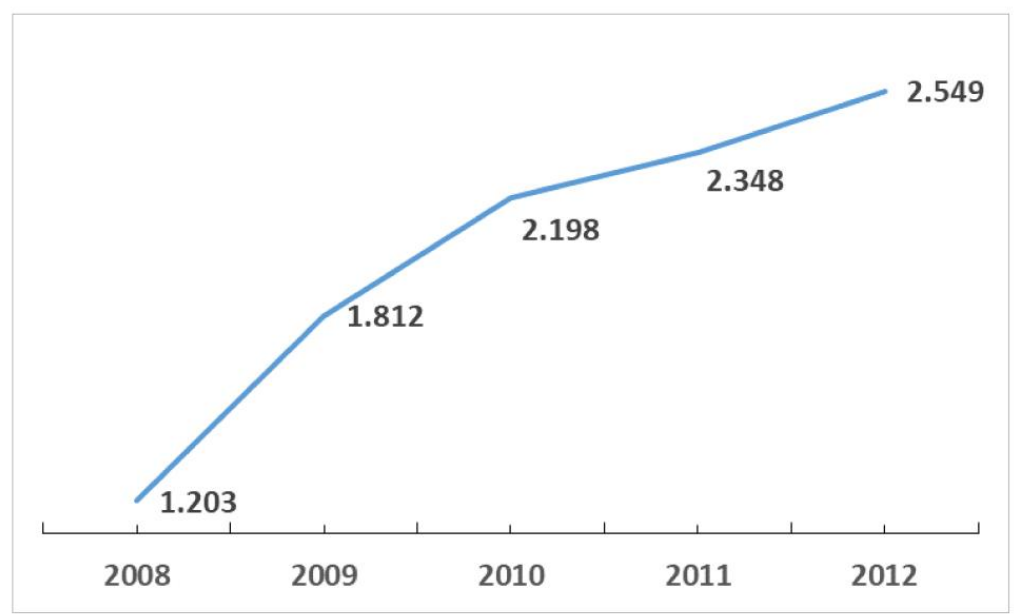

Fonte: Gráfico elaborado pela autora

A partir dos editais dos concursos vestibulares, observa-se um crescimento de 29 no número de cursos de graduação (de 25 cursos em 2008 para 54 em 2012), elucidado pelo Gráfico 6. 
Gráfico 6. Crescimento do no número de cursos na graduação, na UNIFESP

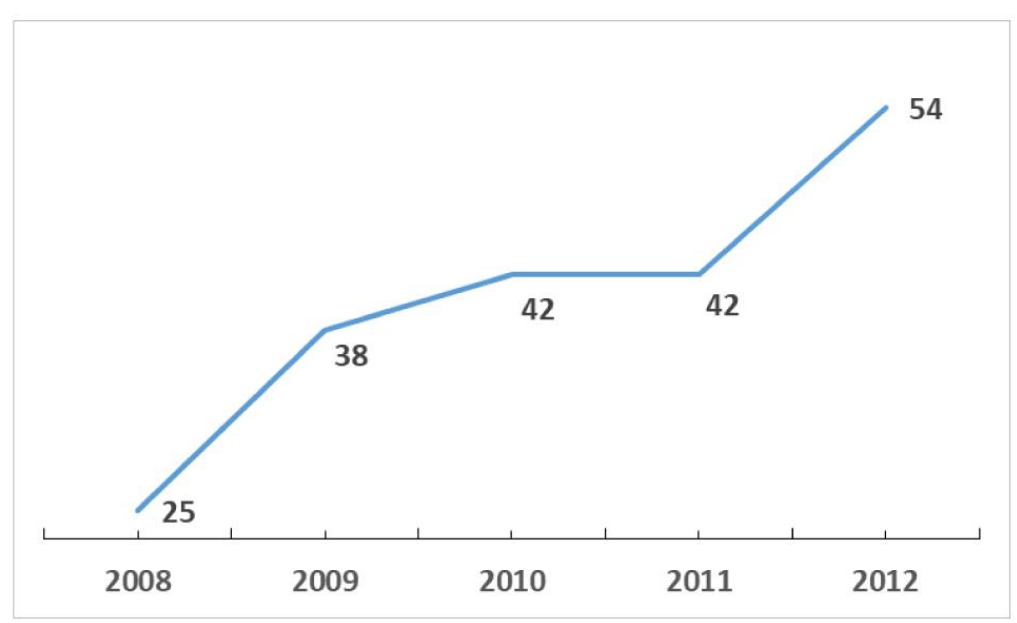

Fonte: Gráfico elaborado pela autora

Os dados demonstrados pelo Gráfico 7, mostraram, para esse período, um crescimento de 5.204 no número de matrículas na graduação, de 3.187 matrículas em 2008 para 8.391 em 2012.

Gráfico 7. Crescimento do no número de matrículas na graduação, na UNIFESP

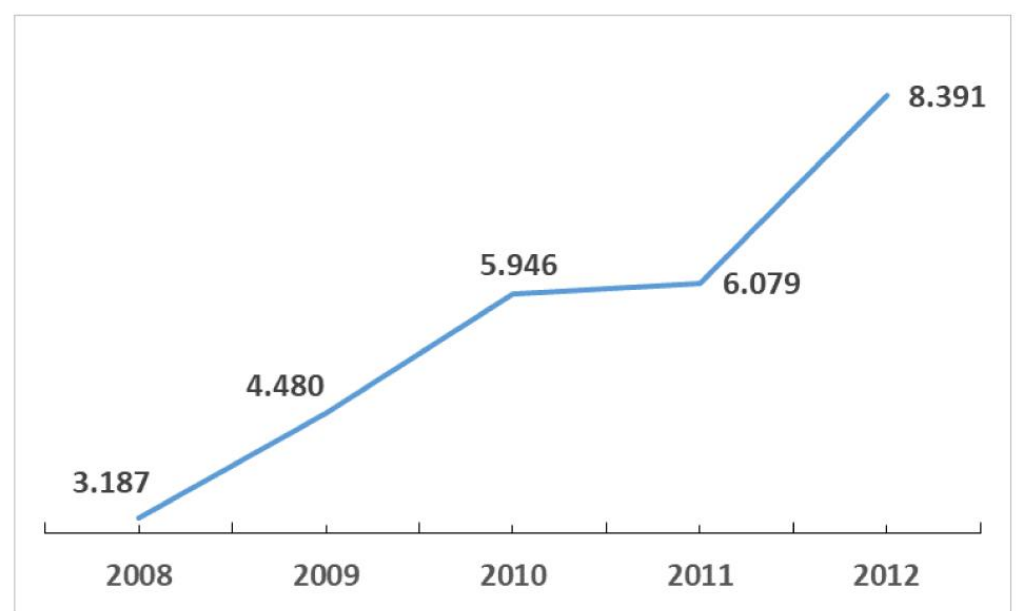

Fonte: Gráfico elaborado pela autora 
O Quadro 1 demonstra a evolução da expansão da graduação da UNIFESP de 2003 a 2012, a partir dos dados quantitativos dos documentos analisados.

Quadro 1. Indicadores globais da primeira fase e da segunda fase da expansão da graduação na UNIFESP

\begin{tabular}{|c|c|c|c|c|c|}
\hline \multirow{2}{*}{ Indicadores } & \multicolumn{2}{|c|}{ Expansão $1^{\mathrm{a}}$ fase } & \multicolumn{2}{|c|}{ Expansão $2^{\mathrm{a}}$ fase } & \multirow{2}{*}{$\%$ Global } \\
\hline & 2003 & 2007 & 2008 & 2012 & \\
\hline Campi & 1 & 5 & 5 & 6 & $500 \%$ \\
\hline Vagas de graduação & 273 & 1.150 & 1.203 & 2.869 & $834 \%$ \\
\hline Cursos de graduação & 5 & 23 & 25 & 54 & $980 \%$ \\
\hline Matrículas na graduação & 1.296 & 2.312 & 3.187 & 9.631 & $643 \%$ \\
\hline
\end{tabular}

Fonte: Quadro elaborado pela autora.

Assim, a partir dos dados quantitativos dos documentos analisados, observou-se um aumento de 2003 para 2012 de 500\% no número de campi na Unifesp, $834 \%$ no número de vagas de ingresso e $980 \%$ no número de cursos. Além desse expressivo aumento quantitativo, a UNIFESP também diversificou sua área de atuação com a inclusão dos cursos de ciências humanas, sociais aplicadas e exatas. 


\section{CONSIDERAÇõES/RECOMENDAÇõES AOS GESTORES DA UNIVERSIDADE}

O processo de expansão da UNIFESP no período de 2003 a 2012, em relação ao que ocorreu no ensino superior público federal no país, pode ser considerado como único entre as IFES brasileiras. Sua singularidade se dá tanto pelo potencial transformador dessa expansão como pelo crescimento do número de campi, cursos e matrículas de graduação em relação aos parâmetros nacionais.

Na primeira fase da expansão das IFES no Brasil (2003 a 2007), a UNIFESP teve um crescimento de $400 \%$ no número de campi, enquanto o crescimento total de campi nas universidades federais no Brasil foi de $53 \%$. O número de vagas de graduação aumentou em $321 \%$ na UNIFESP e 53\% em nível nacional. O aumento do número de cursos da UNIFESP foi de $360 \%$ e do total das universidades federais de $28 \%$. Numa perspectiva regional, o crescimento do número de campi da UNIFESP na primeira fase da expansão correspondeu a $20 \%$ do total de campi criados em toda a região sudeste (aumento de 1 para 5 campi).

Por intermédio da proposta do REUNI (2008 a 2012), o crescimento no número de cursos de graduação na UNIFESP foi de $116 \%$ e de $112 \%$ no número de vagas de graduação. Nesse período, o crescimento do número de cursos de graduação nas universidades federais em geral foi de $66 \%$ e de $54 \%$ de vagas de graduação.

Importante salientar que, além desta significativa expansão pelo projeto REUNI da instituição, foram ainda criados mais um Campus (Osasco) com 4 cursos de graduação e um Bacharelado em Ciência e Tecnologia, no Campus de São José dos Campos.

O crescimento global da UNIFESP no período de 2003 a 2012 foi de $500 \%$ no número de campi e de $980 \%$ no número de cursos. Isso significou um aumento global de $760 \%$ no número de vagas ofertadas pela instituição. Neste mesmo período, o aumento global das universidades federais foi de $106 \%$ no número de campi, $125 \%$ no número de cursos e de $112 \%$ no número de vagas de ingresso.

No cenário da expansão no Brasil, a UNIFESP foi, portanto, uma das universidades que mais se transformou, pois, além de ampliar o número de campi, 
vagas e cursos, a instituição também aumentou sua área de conhecimento: de ciências da saúde para ciências humanas, sociais aplicadas e exatas, com a implementação de propostas pedagógicas inovadoras

Apesar do ritmo intenso da expansão, considerou-se que a mesma deu à UNIFESP a oportunidade da interiorização e de ampliar seu compromisso social de uma universidade pública e socialmente referenciada. Além de ampliar consideravelmente o número de vagas e a possibilidade de escolha de diferentes áreas profissionais, a universidade implantou o ensino noturno, tão necessário para a sociedade.

Frente a esse panorama, importante o desenvolvimento de reflexões acerca desse processo de tamanha magnitude. Esperamos que a leitura do relatório, especialmente pela comunidade da UNIFESP, incluindo seus atuais gestores, possa oferecer subsídios para o desenvolvimento de discussões com vistas à autoavaliação e melhor entendimento dos fatos referentes à expansão da graduação. 


\section{REFERÊNCIAS}

ASSOCIAÇÃO NACIONAL DOS DIRIGENTES DAS INSTITUIÇÕES FEDERAIS DE ENSINO SUPERIOR. Reforma Universitária: proposta da Andifes para a reestruturação da Educação Superior no Brasil. Maio de 2004.

ASSOCIAÇÃO NACIONAL DOS DIRIGENTES DAS INSTITUIÇÕES FEDERAIS DE ENSINO SUPERIOR. Consolidação dos dados acadêmicos, orçamentários e de pessoal referentes aos acordos de metas do Programa de Apoio a Planos de Reestruturação das Universidades - REUNI. [Relatório de Consultoria de Maria leda Costa Diniz]. Brasília (DF). Outubro de 2009.

ASSOCIAÇÃO NACIONAL DOS DIRIGENTES DAS INSTITUIÇÕES FEDERAIS DE ENSINO SUPERIOR. Relatório de Acompanhamento do Programa de Apoio a Planos de Reestruturação e Expansão das Universidades Federais - REUNI. Brasília (DF): ANDIFES, jan. 2010.BRASIL. Decreto de 20 de dezembro de 2003. Institui Grupo de Trabalho Interministerial encarregado de analisar a situação atual e apresentar plano de ação visando a reestruturação, desenvolvimento e democratização das Instituições Federais de Ensino Superior (IFES). 2003b. Disponível em: <http://www.sintunesp.org.br/refuniv/GT-Interministerial\%20\%20Estudo.htm>. Acesso em: 23 out. 2015.

BRASIL. Lei no 10.172, de 9 de janeiro de 2001. Aprova o Plano Nacional de Educação e dá outras providências. Diário Oficial da União, Brasília, DF, 10 jan. 2001a. PNE - 2001-2010.

BRASIL. Grupo de trabalho interministerial. Bases para o enfrentamento da crise emergencial das universidades federais e roteiro para a reforma universitária brasileira. Brasília: [s.n.], 15 de dezembro de 2003.

BRASIL. Ministério da Educação. Reforma da Educação Superior. Documento II. Reafirmando princípios e consolidando diretrizes da Reforma da Educação Superior. Brasilia, 2 de agosto de 2004a.

BRASIL. Lei $n^{\circ} 10.861$ de 14 de abril de 2004b. Institui o Sistema Nacional de Avaliação da Educação Superior (SINAES) e dá outras providências. Disponível em: <http://www.planalto.gov.br/ccivil_03/_ato2004-2006/2004/lei//10.861.htm>. Acesso em: 22 jun. 2015.

BRASIL. Lei no 11.096 de 13 de janeiro de 2005. Institui o Programa Universidade para Todos (PROUNI), regula a atuação de entidades beneficentes de assistência social no ensino superior; altera a Lei No 10.891, de 9 de julho de 2004, e dá outras providências. Disponível em: <http://www.planalto.gov.br/ccivil_03/_ato20042006/2005/lei/L11096.htm>. Acesso em: 22 jun. 2015. 
BRASIL. Ministério da Educação. Expansão das Universidades Federais, o sonho se torna realidade! Coordenação geral: Maria leda Costa Diniz. Brasília. 2006a.

BRASIL. Ministério da Educação. Projeto de Lei n 7.200, de 12 junho de 2006b. Estabelece normas gerais da educação superior, regula a educação superior no sistema federal de ensino.

BRASIL. Ministério da Educação. O Plano de Desenvolvimento da Educação. Razões, Princípios e Programas. Brasília, 24 de abril de 2007a.

BRASIL. Decreto $n^{\circ} 6.096$, de 24 de abril de 2007b. Institui o Programa de Apoio a Planos de Reestruturação e Expansão das Universidades Federais - REUNI. Presidência da República. Brasília, DF: Diário Oficial da União de 25.04.2007.

BRASIL. Portaria n 552 SESu/MEC, de 25 de junho de 2007c: Diretrizes Gerais do Programa de Apoio a Planos de Reestruturação e Expansão das Universidades Federais - REUNI. GRUPO ASSESSOR. Brasília, DF: MEC; Secretaria da Educação Superior, 2007.

BRASIL. Ministério da Educação. Programa de Apoio a Planos de Reestruturação e Expansão das Universidades Federais. Reuni 2008 - Relatório de Primeiro Ano. Brasília (DF), 30 de outubro de 2009.

BRASIL. Ministério da Educação. Relatório da Comissão Constituída pela Portaria $n^{\circ}$ 126/2012, sobre a Análise sobre a Expansão das Universidades Federais 2003 a 2012. Brasília, 2012a.

BRASIL. Ministério da Educação. Análise sobre a Expansão das Universidades Federais 2003 a 2012. 2012b. Disponível em:

http://portal.mec.gov.br/index.php?option=com_docman\&view=download\&alias $=1238$ 6-analise-expansao-universidade-federais-2003-2012-pdf\&ltemid=30192. Acesso em: 23 ago. 2015.

BRASIL. Ministério da Educação. A democratização e expansão da educação superior no país 2003 - 2014. Balanço das principais políticas e programas. 2015[?].

FRANCO, M.L.P. B. Análise de conteúdo. 4ª Ed. Brasília: Liber Livro Editora, 2012.

GIL, A. C. Como Elaborar Projetos de Pesquisa. 4. ed. São Paulo: Atlas, 2002.

LÜDKE, M.; ANDRÉ, M. E. D. A. Pesquisa em educação: abordagens qualitativas. São Paulo: EPU, 1986. 99p.

UNIVERSIDADE FEDERAL DE SÃO PAULO. Relatório de Gestão de 2003, de novembro de 2003. 
UNIVERSIDADE FEDERAL DE SÃO PAULO. Relatório de Gestão de 2004, de novembro de 2004.

UNIVERSIDADE FEDERAL DE SÃO PAULO. Relatório de Gestão de 2005, de novembro de 2005.

UNIVERSIDADE FEDERAL DE SÃO PAULO. Relatório de Gestão de 2006, de novembro de 2006.

UNIVERSIDADE FEDERAL DE SÃO PAULO. Relatório de Gestão de 2007, de novembro de 2007.

UNIVERSIDADE FEDERAL DE SÃO PAULO, Edital de retificação do Concurso Vestibular. UNIFESP 2008, 4 de setembro de 2007.

UNIVERSIDADE FEDERAL DE SÃO PAULO. Programa de Apoio a Planos de Reestruturação e Expansão das Universidades Federais (REUNI) - Proposta de adesão de 23 de abril de 2008.

UNIVERSIDADE FEDERAL DE SÃO PAULO, Edital Concurso Vestibular UNIFESP 2009, 3 de setembro de 2008.

UNIVERSIDADE FEDERAL DE SÃO PAULO, Edital Concurso Vestibular UNIFESP 2010, 7 de julho de 2009.

UNIVERSIDADE FEDERAL DE SÃO PAULO. Balanço do Primeiro ano do REUNI da UNIFESP, de 31 de outubro de 2009.

UNIVERSIDADE FEDERAL DE SÃO PAULO. Plano de Desenvolvimento Institucional (PDI) 2005-2010. São Paulo, SP, dezembro de 2009.

UNIVERSIDADE FEDERAL DE SÃO PAULO, Edital Concurso Vestibular UNIFESP 2011, 24 de agosto de 2010.

UNIVERSIDADE FEDERAL DE SÃO PAULO, Edital Concurso Vestibular UNIFESP 2012, 5 de setembro de 2012. 


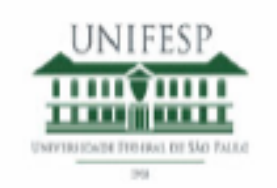

Comitê de Ética em Pesquisa

Şฯ Paub, 08 de dezembro de 2015 CEP N 7720261115

IImo(a). Sn(a).

Pesquiador(a): Muria Bemadete De Noronha Dantas Rossetto

Depto'Cisc: Centro De Desenvolumento Do Ensino Superior Em Saúde (cedess)

Paulete Goldenberg (orientador)

Titulo do projeto: "A EXPANSÄO DA UNIVERSIDADE FEDERAL DE SÄO PAULO NO PERIODO DE 2005 A 2015 : DESAFIOS EAPRENDIZADOS".

Parecer Consutstanciado do Comitê de Ética en Pesquisa UNIFESPIHSP

A expansâo da universidade pública brasileira é urra luta histórica da corrunidade, dos eduçadores e da sociedade e aconteceu dentro de um determinado momento sócio-histórico, com a abertura de aursos na graduaçẫo. Na Lhiversidade Federal de Sấ Paulo (UNIFESP), houve uma conergência de faros intemos, entre eles, a vontade da Reitoria com a política eduçacional dirigida às hstituiçốes de Ersino Superior (IES) e externos, como a preş̃o da própria sociedade, que reivindicava uma resposta do universicde à crescente demanda por uma uaga no ensino superior. Alinhada com as diretrizes da construção de uma universidade democrática e de quaidade, a UNIFESP vai ao encontro do processo de expanşo do ensino público superior, ampliado para seis campi e suas iuturas unidades universiárias, que ganharam mais independência a partir do momento em que cada campus teve o seu próprio diretor açdêmico. Esta pesquisa tem por objetivo conhecer este processo de expanş̃o da UNIFESP no peŕodo de 2005 a 2015, traçando um panorama geral da

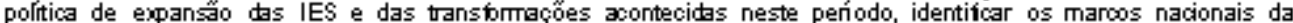

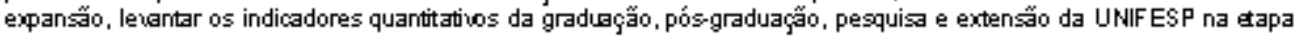
que

antecedeu o processo de expanşo, descrever a adeş̃o da UNIFESP ao movimento de expansâo

no período de 2005 a 2012, mapear as expansốes que ocorrerm na UNIFESP após 2012 e aralisar a expansâo da UNIF ESP emrelação aos indicadores qualitativos da graduação, pósgradıçẫo.

pesquisa e extenş̃o no ano de 2015. Para alcançar os objetivos propostos, o percurso metodológico será de cáter exploratório, descritivo-analítico, tipo estudo de caso e os dados ser̃o produzidos por meio de pesquisa documenta. A opção metodológica da pesquisa considerará os anos de 2005 a 2015 para a

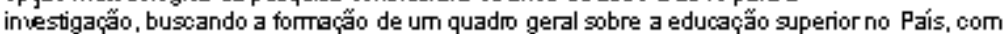

êntese na expansão das IES. Partira, portanto, do geral para o particula, como brma de compreender o caso mais expećico da expans̃o da graduação na UNIFESP, mostrando as fases desta expanş̃o

0 Corritê de Ėica em Pesquisa da Universidade Federal de São Paulo/Hospital São Paulo, na reuniâo de 04/12/2015, ÁNALLISOU A AROVOU o protocolo de estudo acima referenciado. Apartir desta data, é dever do pesquisador:

1. Comunicar toda e qualquer alteração do protocolo.

2. Comunicar imediatamente ao Comitê qualquer evento adverso ocorrido durante o desenvolvimento do protocolo.

3. Os dados individuais de todas as etapas da pesquisa devem ser mantidos em local seguro por 5 anos para posá vel auditoria dos órgâos competentes.

4. Relatórios parciais de andamento deverâo ser enviados anuajmerte ao CEP áé a condusấo do protocolo.

Alenciosamente,

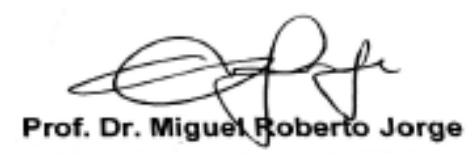

Coordenador do Comite de Ética em Pesquisa da

Universidade Federal de Să Paula/Hospital Să Paulo

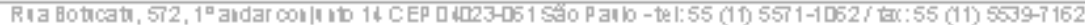

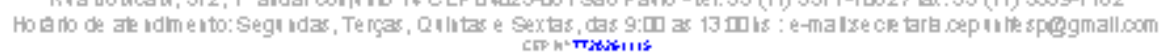

